Historic, Archive Document

Do not assume content reflects current scientific knowledge, policies, or practices. 

$\frac{1}{4}+1$

\section{(Gipnea Oatalughe}

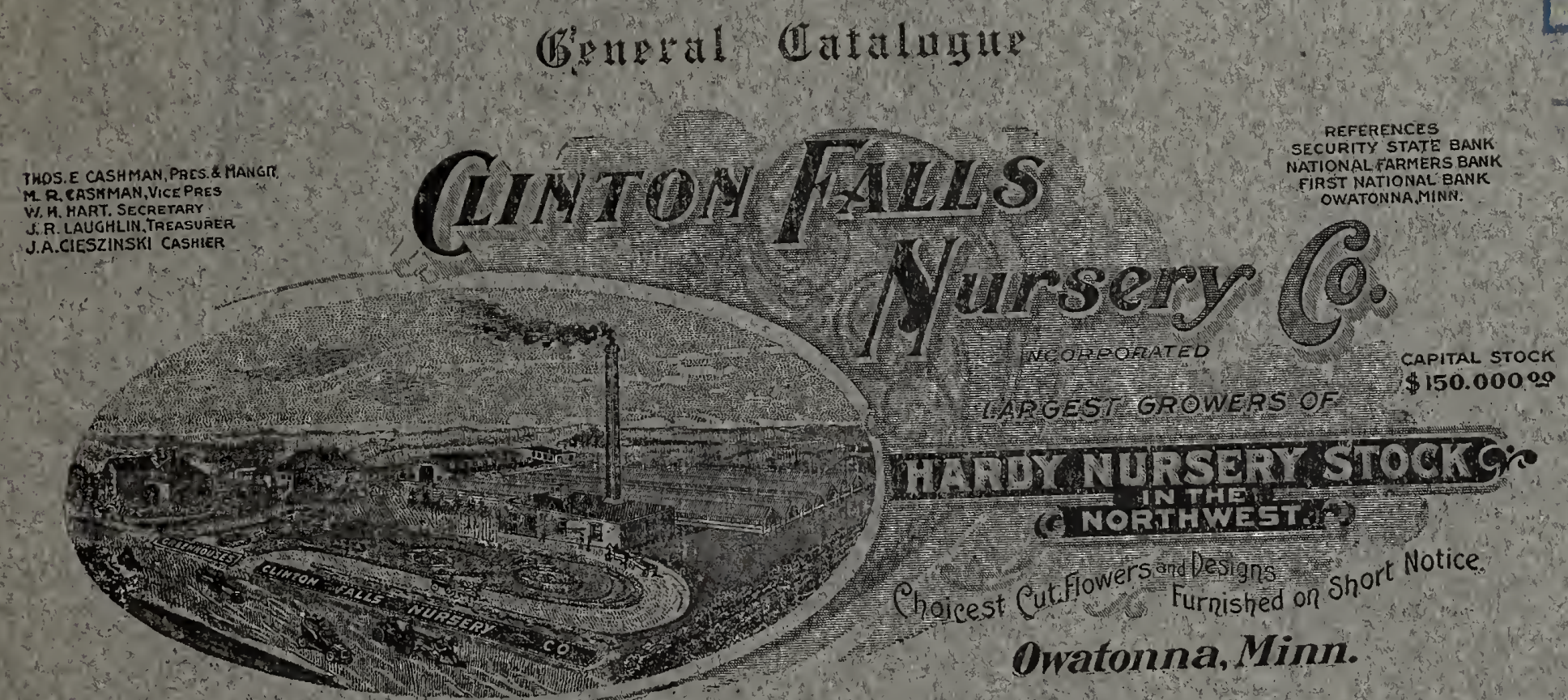

LITHAR + JUL 81920

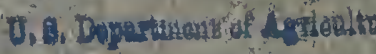

70,000 Square Feet of Greenhouse Glass 



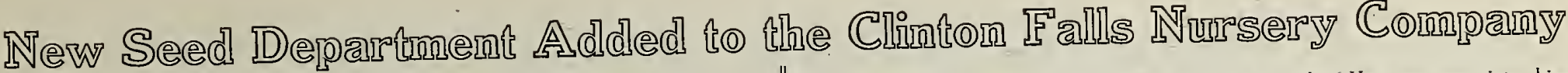

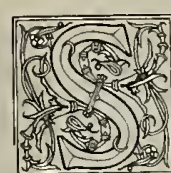

NCE the inception of the Clinton Falls Nursery Company it has been our one im and ambition to please our customers by giving them the best values for their money, and to hold their patronage by fair treatment and square dealing. That we have been successful in this is unquestionably demonstrated by our That we have been successful in this is unquestionably growth of business and the flattering testimonials received from all parts of the Northwest. No Nursery in the United States can show such a tremenduous increase of business in so short a time as that shown today on the books of the Clinton Falls Nursery Company. This ever increasing business has repeatedly made demands upon us that have apparently seemed impossible to satisfy. It demanded that we equip ourselves what Proof Storage Houses and Root Cellars, imwith all modern appliances in the way of Frost Proof Storage Houses and Root Gellars, immense Packing Sheds, Railroad facilities on our grounds, our own Printing Offices, thorough ly equipped through-out, where our Gatalogs, Girculars and all printed matter are turned out, and all the Mammoth Equipment necessary to operate the Greatest Nursery in the West. It arge tracts of land be added, from time to time, on which to grow the necessary stock to take care of the business, until now the sightseer, driving in almost any direction from Owatonna, can see great blocks of trees owned by the Clinton Falls Nursery direction from Owatonna, can see great blocks of tremployed in caring for the growing stock. The any, where hundreds of a Green House department, and this department now boasts to our Nursery business a Green House department, and this department now boasts 100,000 feet of glass, covering hundreds of thousands of Roses, Garnations and all other hothouse plants. From here are shipped daily by mail and express scores of boxes con. taining choice cut flowers and designs, until now lovers of flowers in Minnesota, lowa and the two Dakotas know that their wants in this line can be supplied on short notice by the Clinton Falls Nursery Company, telephone or telegraph charges being paid by the company on all orders of five dollars or over. We flnd we have not yet satisfied our trade. Thousands of letters and inquiries are annually coming to our office asking us to furnish them new and reliable arden. Naturally we should be in a position to do so, varieties of seeds for both farm and garden. Naturally we should be in a position to do so, for the seed and nursery business are so closely related that neither department is complete without the other, and the reliable nurseryman, through his knowledge of experimental work, is expected to furnish his customers seeds, trees and fowers best adapted to their peculiar climatic conditions. He certainly should be in a position to do this for there is no class of men more conversant with nature's beautiful system of evolution, more familiar with the peculiar characteristics of plants, trees and flowers than is the nurseryman. The nurseryman, to be successful, must be a close student of nature's work. He must associate himself with the baby plants, studying their likes and dislikes, and by comparing the results of his observations and experiments, be enabled to assist nature in producing the highest standard of excellence.

The thorough nurseryman is therefore nature's medium and advance agent to the points out the road to success and the wise planter, and he who would sow for planter; he points out the roatest results, should lose no opportunity to procure seeds of the highest standard that the greatest results, should lose no opport
he may keep pace with nature's progress.

Realizing the great opportunity afforded us to supply our thousands of customers with seeds of high standard, and thereby assisting them in the great nature problem, we have concluded to lay the foundation of a seed department that will be on a par with our nursery and greenhouse business. Beginning with a knowledge that the foundation of all reliable institutions is laid broad and deep, we have begun by gathering together, at a cost bordering on farts of the world. These seeds noted for their purity and profancy prices, seeds from all parts of the world.

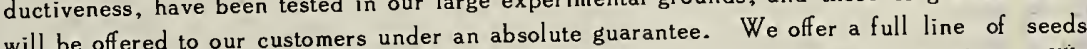
to the public this our cur, and solicit inquiries re to the public this year, and solicit inquiries regarding new are now prepared to furnish seeds that will increase the present crop yields from 25 to 50 per cent. Every planter in the Northwest realizes that in order to obtain the best results from his lands he must, from time to time, change his seed and it will be of value to him to know je Clinton Falls Nursery Company purposes to spare no expense in establishing here in the Middle West a reliable distributing center for pure bred seed, and we have secured the services of men scienced in this work to assist us in the undertaking, and no expense has been spared to equip the department in a thorough and complete manner.

This announcement is made at this time in order that our customers may be enabled to lace their orders for future delivery and also to inform the public in general that the Glinton Falls Nurery Company are now prepared to put on the market pure bred seeds for both farm and garden.

Trusting that our business realations will be as friendly in the future as they have been in the past, and thanking our customers one and all for past patronage, we are, Yours for Business,

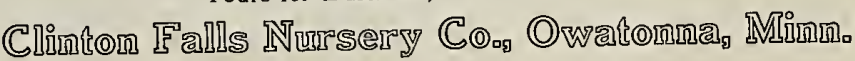




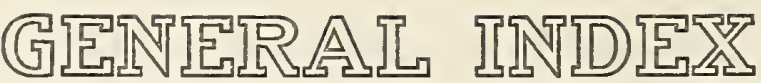

Apples.

Asparagus

Blackberries

Gurrants.

Gherries

Grabs and Hybrids

Dewberries....

Crapes (Black Varieties)

Grapes (Red and White Varieties)

Cooseberries

High Bush Cranberry

Horse Radish

Improved Dwarf Juneberry

Loganberry

Nut Trees

Plums

Pears (Winter Varieties)

Peaches

Russian Apricots

Rhubarb

Raspberries.

Strawberry Raspberry

Strawberries

Hardy Shade and Ornamental Trees

Alder

Ash .................

Beech

Birch

Box Elder

Gatalpa

Grerry (Ornamental)

Dogwood

Elm

Hackberry

Horse Chestnut...

Larch

Linden.

Locust
28 to 32 Landscape Architecture

52 List of trees recommended for various purposes 49 “ 50 Maple

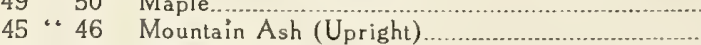

39 “ 40 Mulberry (Russian)

$\begin{array}{llll}33 & 34 & \text { Oak } \\ 50 & \text { “ } & 51 & \text { Poplar }\end{array}$

"Soplar

44 Willow

44 “4

\section{Weeping Trees}

Beech.

Birch (Gut leaved)

Elm (Gamperdown)

40 Mountain Ash....

38 “ 39

Willows (Tea s)

Barberry (For hedges)

$61 \quad$ Climbing Roses

Garagana (Siberian Pea tree)

Honey Locust

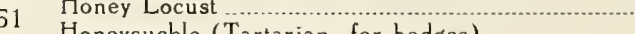

Lartarian, for hedges)

Russian Olive.

55

Arbor Vitae.

\section{Evergreens}

Austrian Pine

Gedar..

Hemlock

Juniper

Pine

Spruce

\section{Hardy Flowering Shrubs}

Almond

Althea.

Barberry (Ornamental)

Buffalo Berry.
Deutzia.

Fringe Tree.

Golden Elder

Honeysuckle (Upright)

Hydrangea

Lilac.......

Spirea

Syringa

Weigelia

$0 \square$

Ampelopsis

Glematis

Honeysuckle (Climbing)

Matrimony Vine

Wisteria

\section{Roses}

Hybrid Perpetual Roses

Miscellaneous Rose

Moss Roses

Tree Roses

Hardy Climbers

Dahlias

Hyacinths

Tulips...

Gladiolus

\section{Hardy Perenials}

Archillea

Golden Glow

Jonquils

Narcissus (or Daffodils)

Phlox

65 Paeonies

65 Loose Cut Flowers

65 Farm and Carden Tool

65 Spraying Aparatus
65

66

66
66

66

68

68 “ 68

69
69

71 “ 72

69 “ 70

72

73

73 * 74

74
75

75

76

76
76 
CLINTON FALLS NURSERY COMPANY, OWATONNA, MINNESOTA

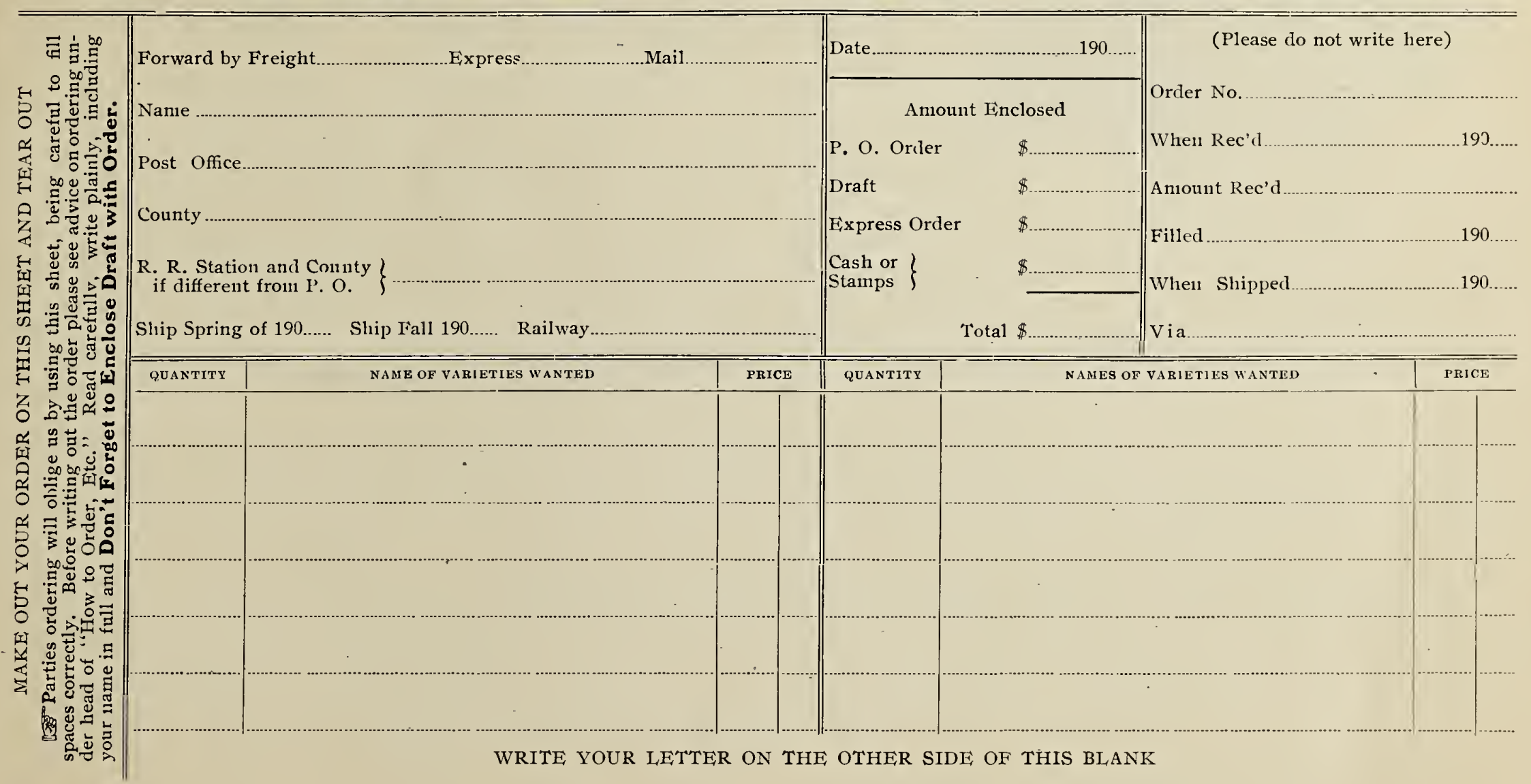




\section{BUSINESS DETAILS}

Remiltance for Amount must, in all cases, accompany the order.

How to Send Money. Money can be sent safely either by Express or Post Office Order, Draft, or Registered Letter. Always send in this manner at our risk.

When You Order do not forget to sign your name. Write it plainly and give your full address, including Town, County and State.

Postpaid by Mail, means that is all that it will cost you. Kach package will be done up securely, plainly directed, and the full postage paid on it by us, and safe arrival guaranteed; we refilling any order that is lost on the way, or has any of its contents injured, free of cliarge.

By Freight or Express, means that we will deliver the stock to the Fxpress or Railroad Company here, and the purchaser pays all the transportation cliarges upon receipt of the goods.

We Do Not Send C. O. D, unless 25 per cent. of the money is sent with the order. Fiverything is plainly priced, and return charges on money are an unnecessary expense.

In Corresponding, always sign your nan1e alike each time.

Terms, Cash, unless by special agreement. Packing done in a most careful manner free of charge.

Packages will be delivered at the railroad station, after which thay are at the risk and expense of the purchaser, and in case of loss or delay the purcliaser must look to the forwarding companies alone.

No Claims will be allowed unless made within ten day's after receipt of goods.

We Exercise Care that all our stock shall be genuine, unmixed and true to name and quality represented, and accept your orders with the understanding and agreement that should any prove untrue to name, we will replace them with the gelluine, but are not liable in any instance for damages in excess of the original invoice price received for the stock that proves untrue.

Correspondence Solicited, or if you can conveniently visit our Nursery Grounds we will take pleasure in showing you the stock growing in our fields and our excellent facilities which enable us to carefully handle your orders.

YOURS RESPECTFULLY

Clinton Falls Nursery Company 


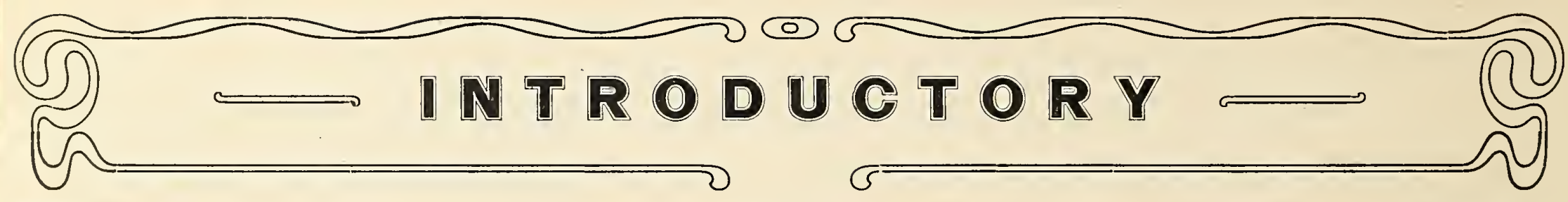

Tा7 E take great pleasure in presenting to the Fruit Growers of the Northwestern and Central States, our new, revised and Illustrated Catalogue. In presenting 1. this Catalogue it has been the aim of the (linton Falls Nursery Co. to give to the public the latest and most complete line of hardy and desiral,le Fruit Trees, Shrubs and Ornamental Trees now growing in the Clinton Falls Nurseries. Our experience in the nursery lusiness has proven beyond a douht that in order to be successful growers, we must grow hardy stock. Our success as growers, we are convinced, is attributable to the unspaning efforts on the part of the Manager to secure the services of the best and most experienced men in the line of tree growing; whose knowledge of the nature and constitution of every plant, coupled with the skill to detect all defects has covered the broad acres of the Clinton Falls Nursery with the largest and most comple:e line of IIardy Nurserv Stock in the great Nortliwest. Our great success in the field, we attribute to the fact that we sell nothing but first class stock and send our agents out witli instructions to sell, wherever possible, only tried and tested varieties, which have been proven by years of thorough trial to be of the greatest value to the planter. We do not clain to be the oldest nursery in the Northwest, for in looking around us, we find many nurseries which date their listory back thirty or forty years, are no larger today than they were years ago. We do claim, however, that we grow more Nursery Stock and sell more goods than any other Nursery in the Nortliwest. We are ready to convince anyone who will favor us with an investigation, that our statements are correct.

\section{WHAT WE HAVE TO SHOW}

The average man is so engrossed and taken up with affairs of business life that he seldon spares time to look out into the world and see the beauty and granduer with which nature clothes leerself. The average farmer can scarcely take time to leave the tilling of liis soil and the care of lis stock to acquaint hiniself with the marvelous manner in which mother earth provides herself with stately trees, luscious fruits and beautiful flowers.

To lovers of the beautiful and those who are inquisitive in the mysteries of real life, nothing could be more interesting or appreciated than a visit to the real cradle of nature. We therefore extend to the general public a cordial invitation to visit the Clinton Falls Nursery at Owatonna, Minn. We will show you our gi eat fields of Apple Trees of different sizes, 1umbering over two millions, our large blocks of Plum and Cherry of aluiost a million trees, our million of Shade Trees. our millions of Evergreens and Ornamental Trees, our millions of Small Fruits and Shrubs, our millions of Strawberry Plants, our thousands of Geraniums, Coleus, Verbenas, Feverfews, Cannas, Ageratums and dozens of other kinds of plants used for ornamental and bedding purposes.

We will slow you the best equipped Greenhouses West of Chicago, filled to the brim with beautiful Roses, Carnations, Smilax and all kinds of season and potted plants. We will make you acquainted with our Cut Flower growers, designers and decorators, who cannot be excellød in their line and who will le pleased to show you their work. We can show you one of the largest equipments and best facilities for handling Nursery Stock in the United States, with private railroad trac'ss to our Gre enhouses to deliver our coal supply and trat ks through our packing shed, enabling us to place our shipments in cars on our own premises. You will see how with our equipment it is possible for us to ship sucl large quantities of stock to our customers all over the country without dissappointment or delay. We are sure you will not regret a visit to this Nursery and you will go home with the assurance that you have marle a visit to the greatest institution of its kind in the Northwest. 


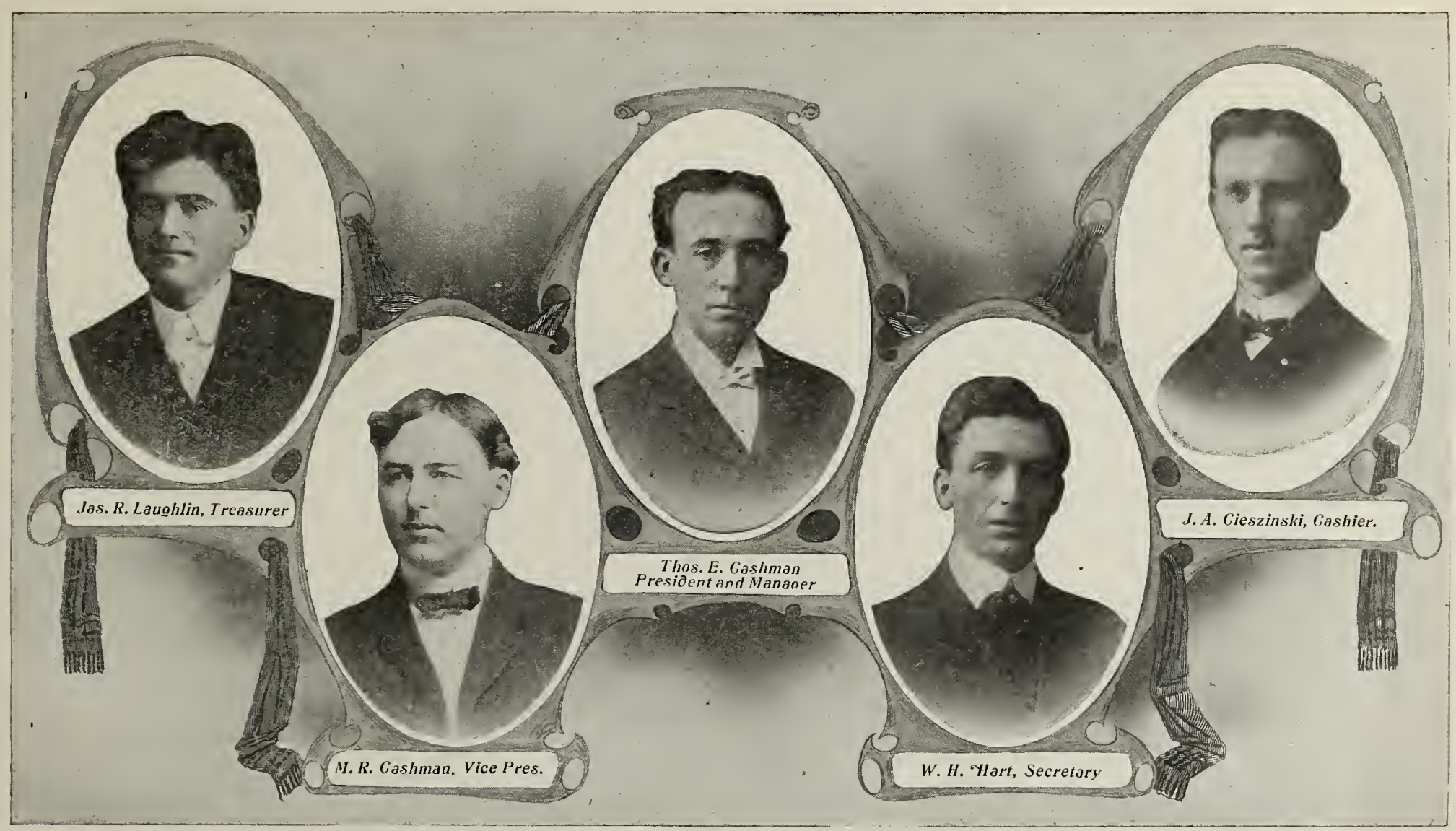

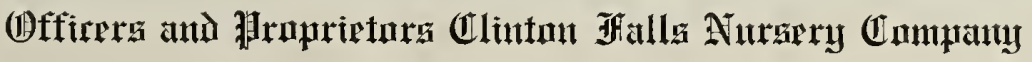




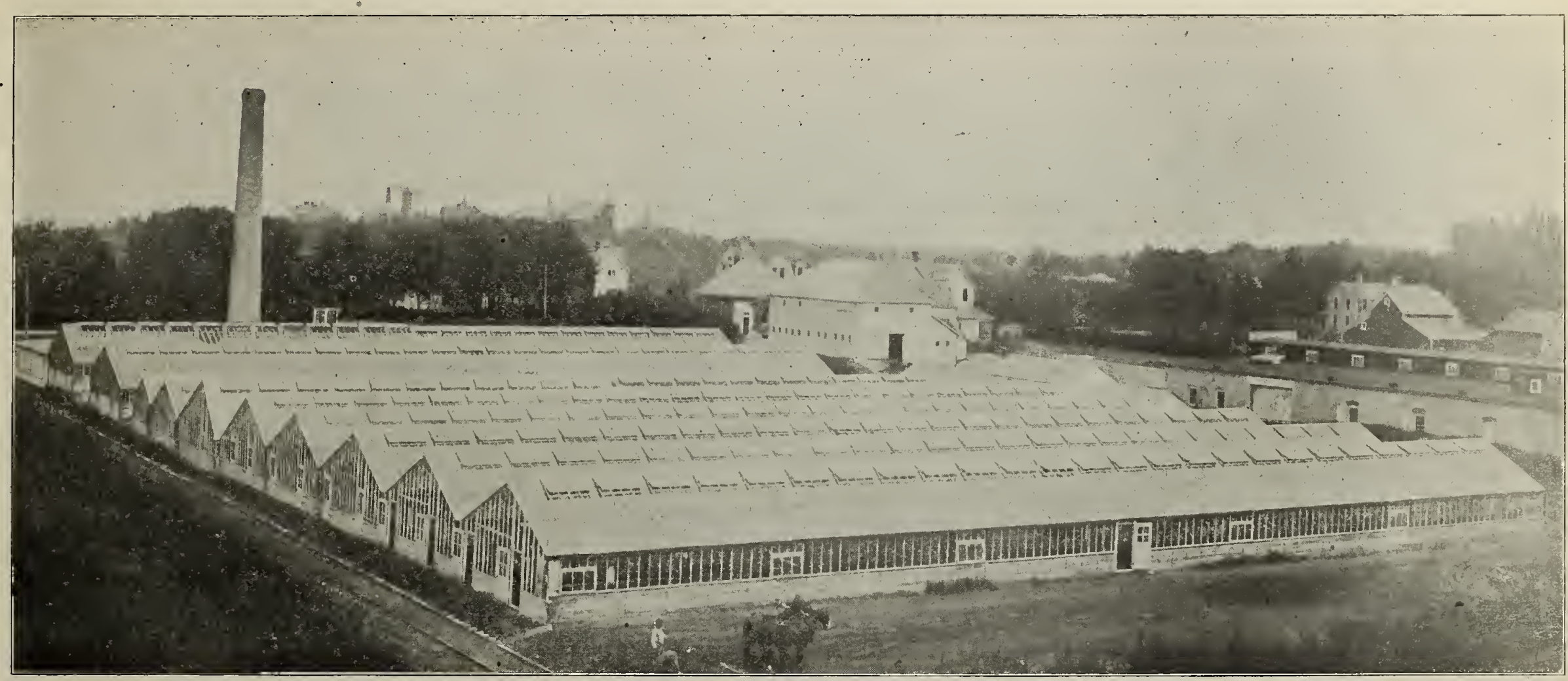

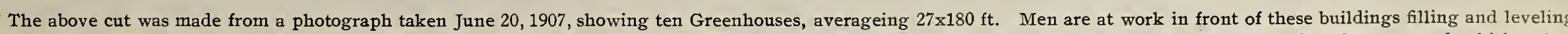

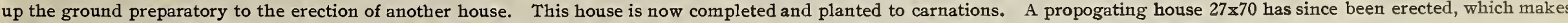
an addition of nearly 9,000 square feet to our greenhouses since August, 1907. 


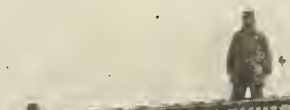

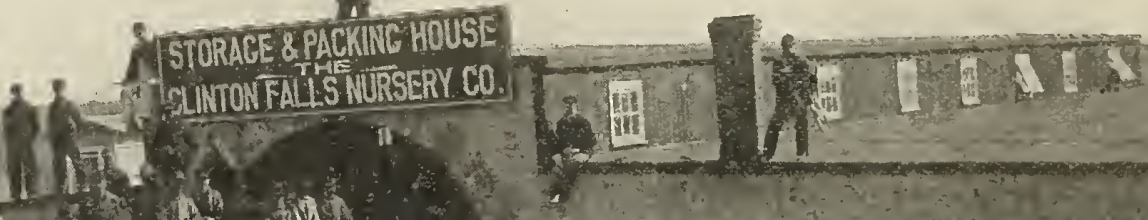

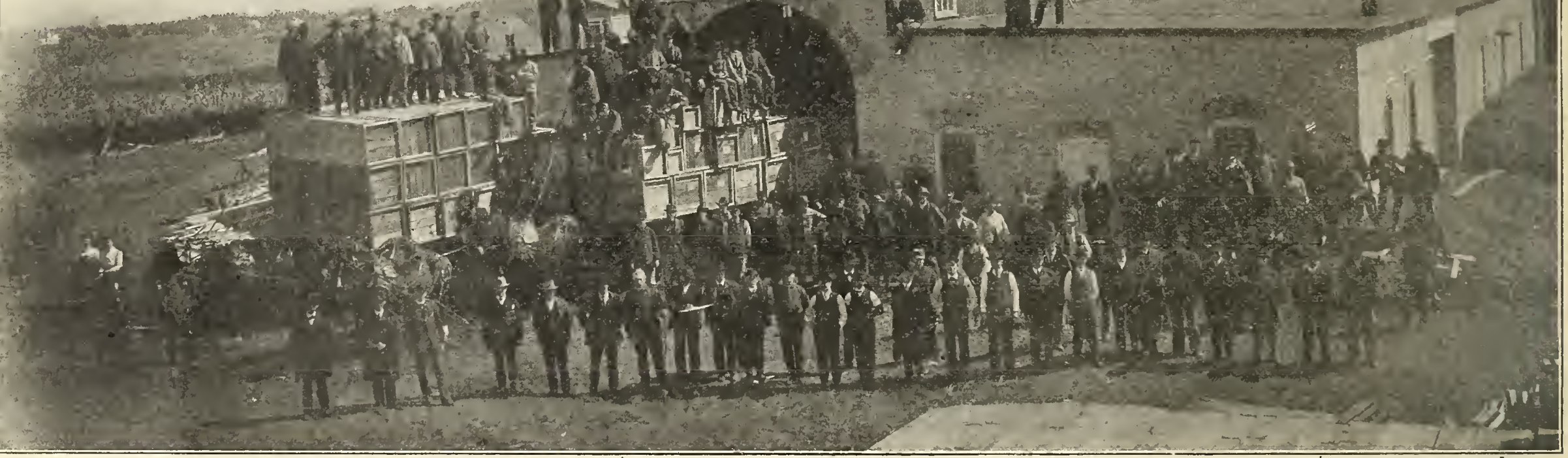

Storage building and a portion of crew employed in packing department of Clinton Falls Nursery Co. This picture only shows a portion of the packing sheds, 

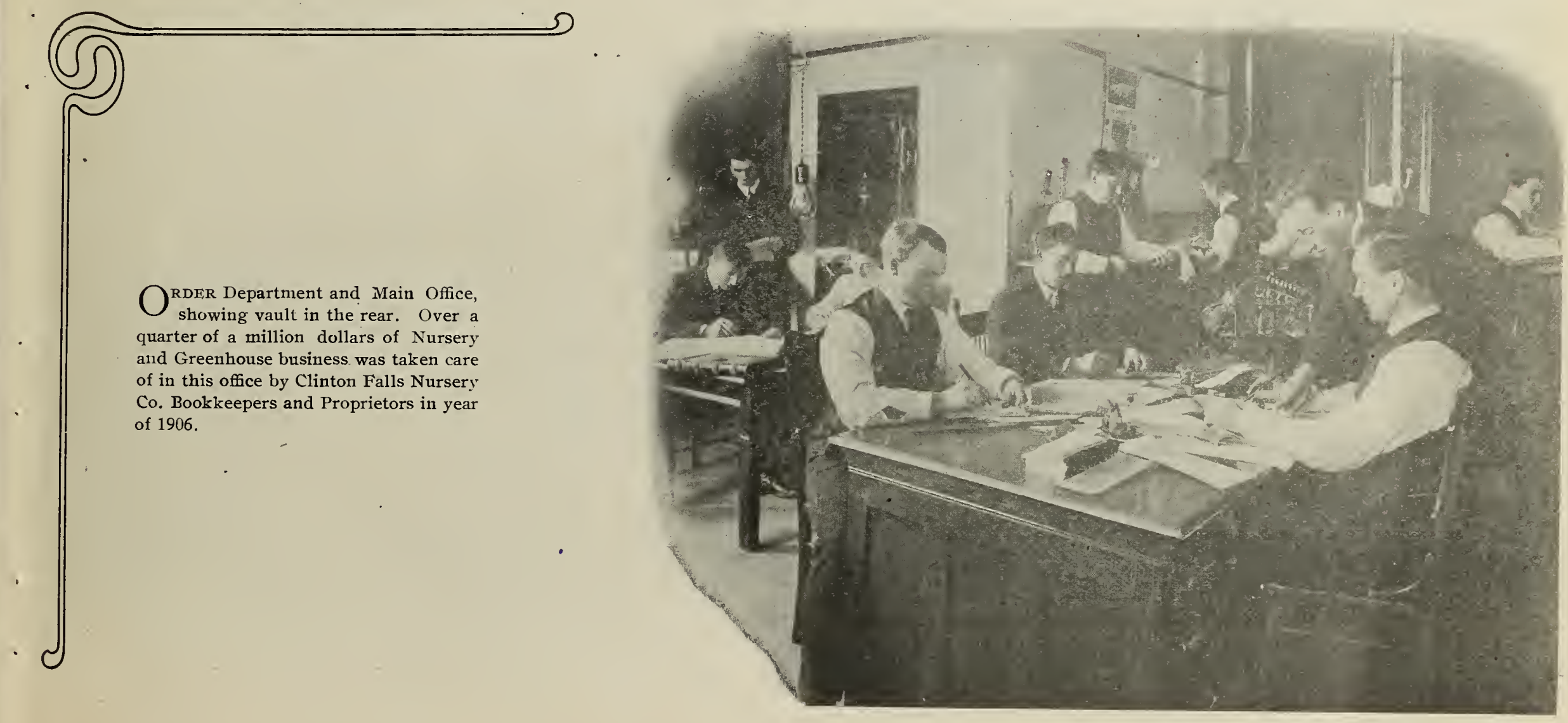


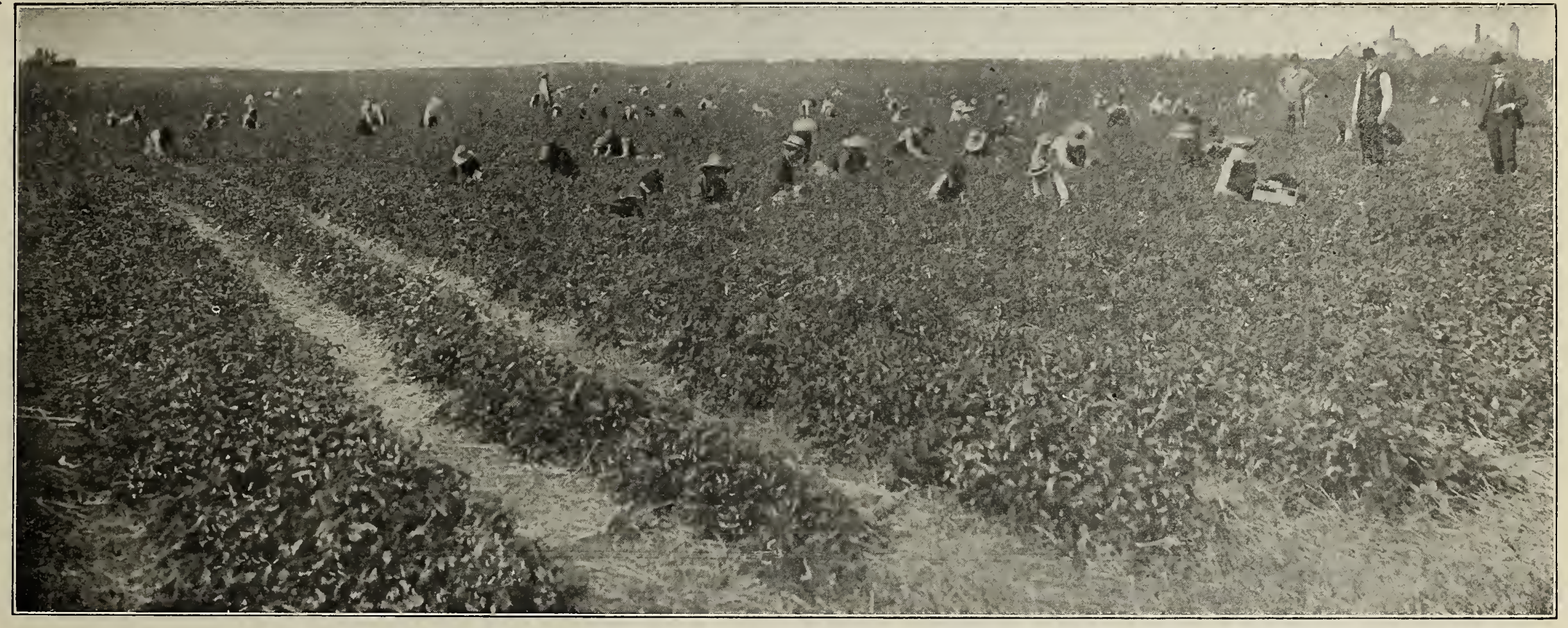

Harvesting the Strawberry crop on Clinton Falls Nursery Co.'s grounds. We guarantee 100 quarts of berries each year from 100 good Strawberry plants set and properly cared for. 


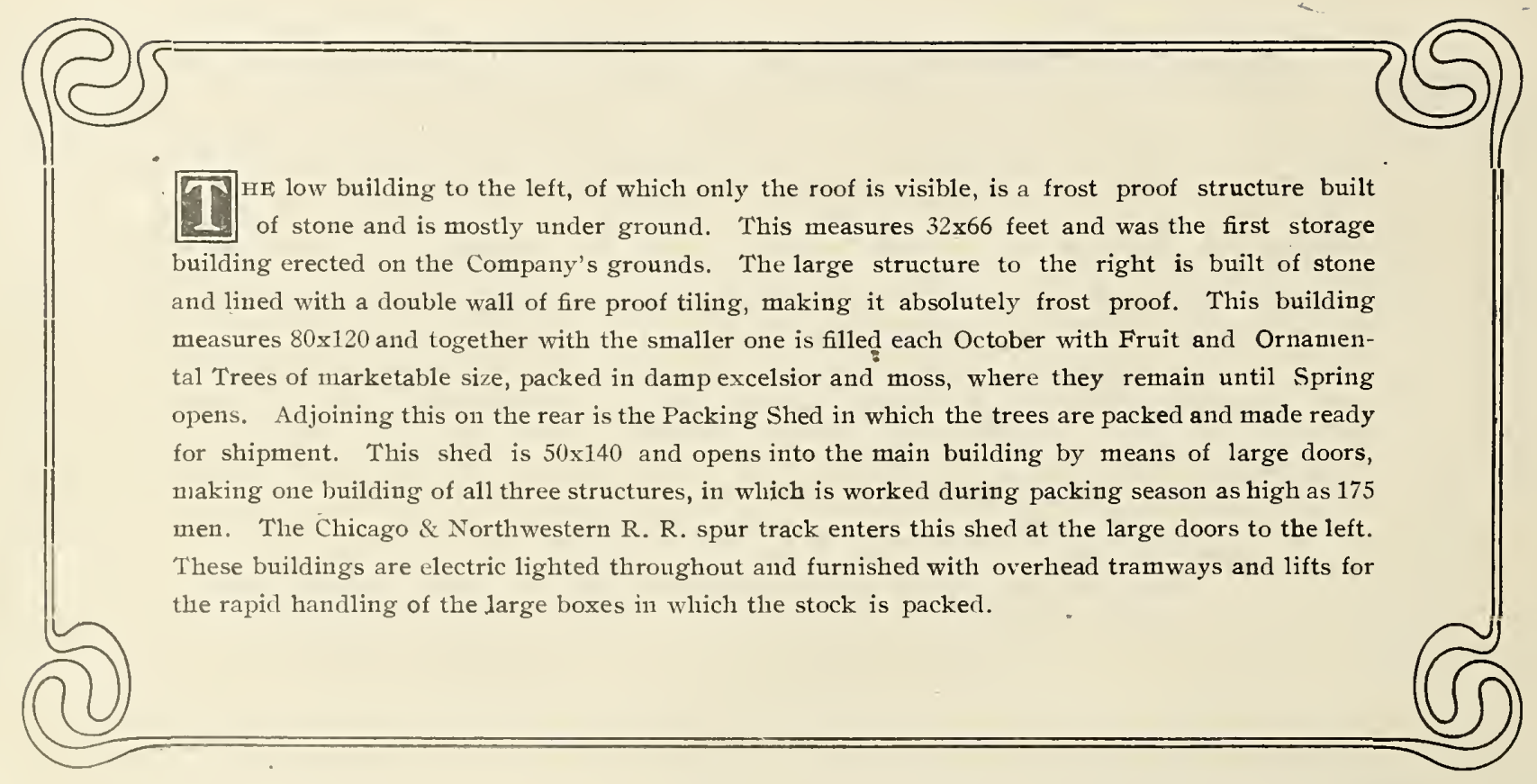




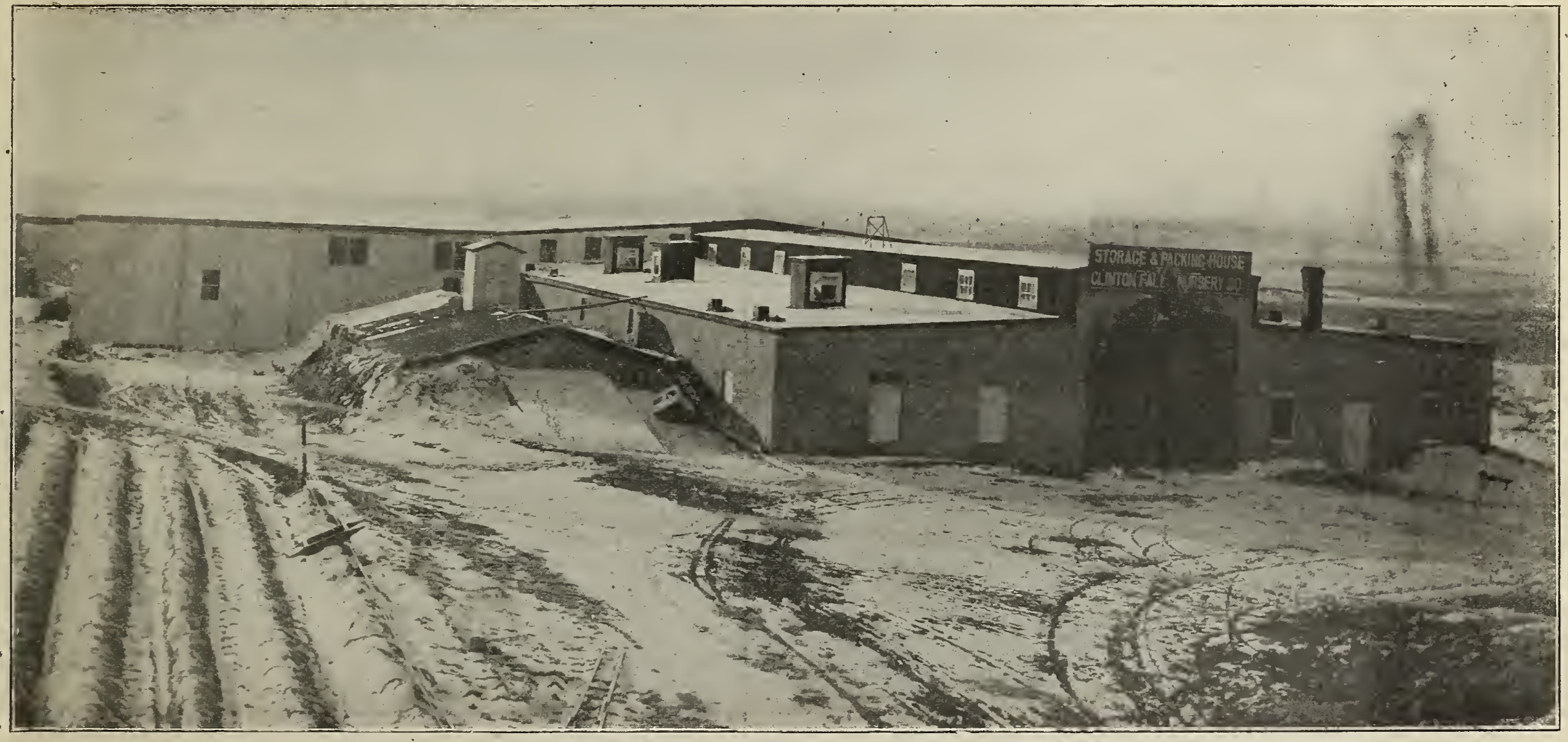

Winter scene of Storage Building and Packing House on. Clinton Falls Nursery Co.'s grounds. Description on opposite page. 


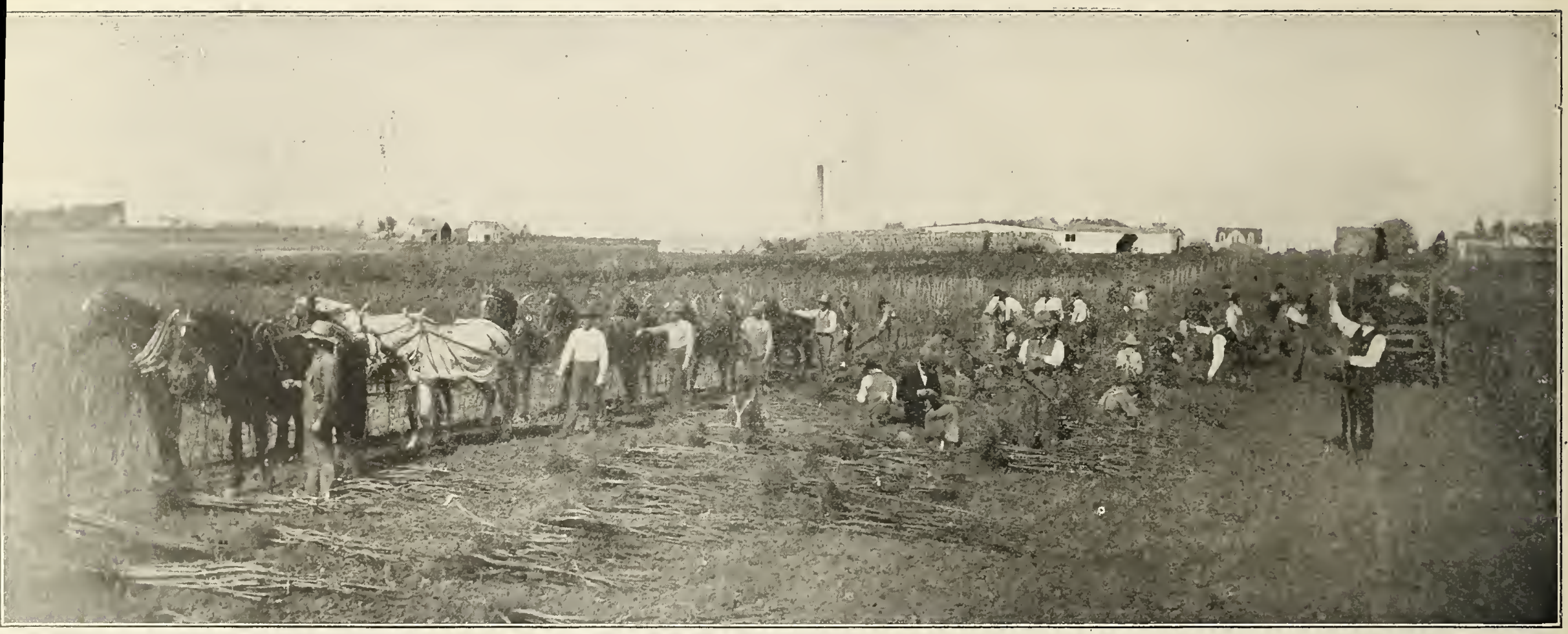

Digging Apple Trees on Clinton Falls Nursery Co.'s grounds. Company's buildings in background. A machine drawn by five large teams passes under the row. The machne is followed by a crew of men who pull, grade and tie the trees in bundles. They are then loaded onto wagons and hauled to the cold storage building, arriving there only a few ninutes after being pulled. 

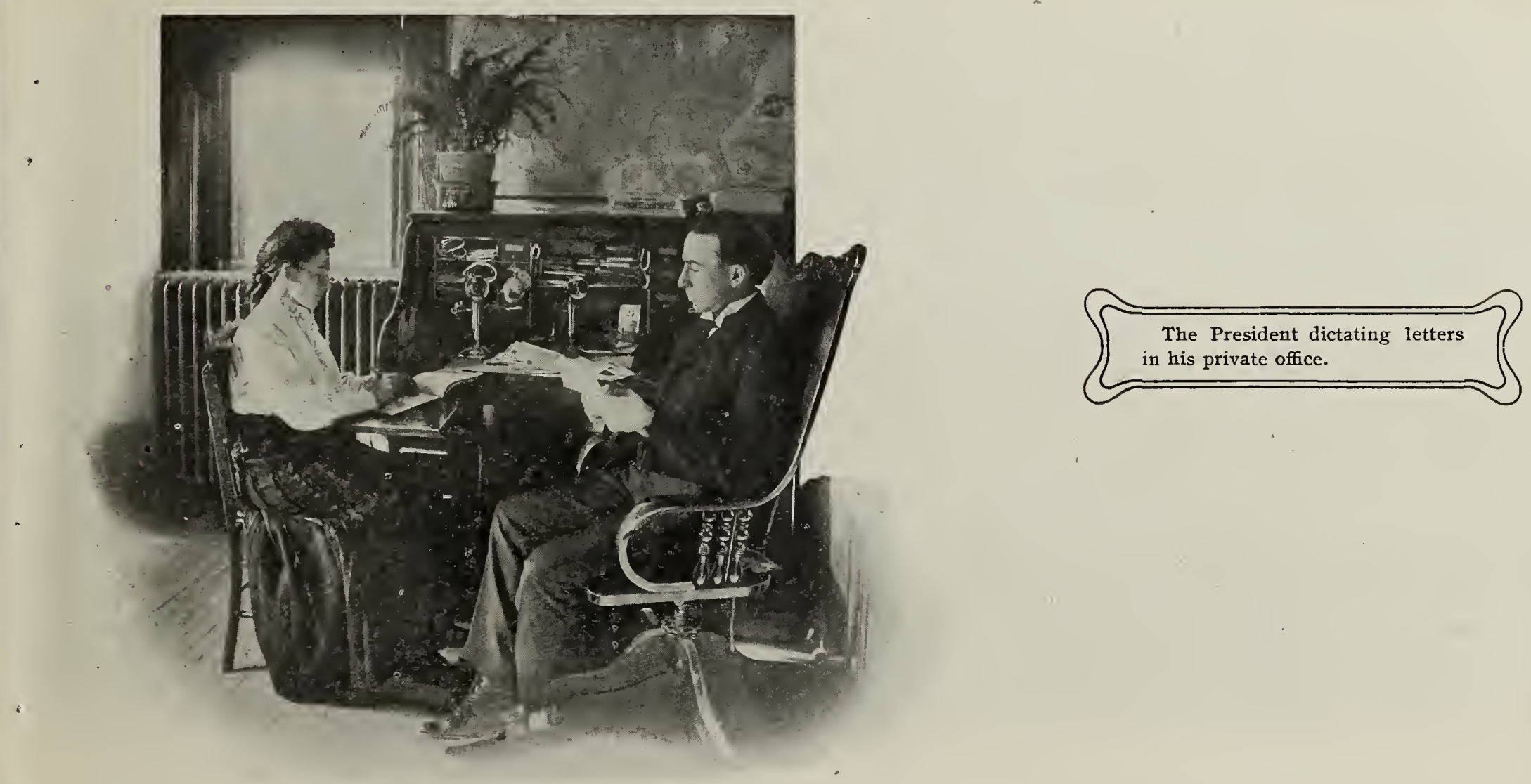


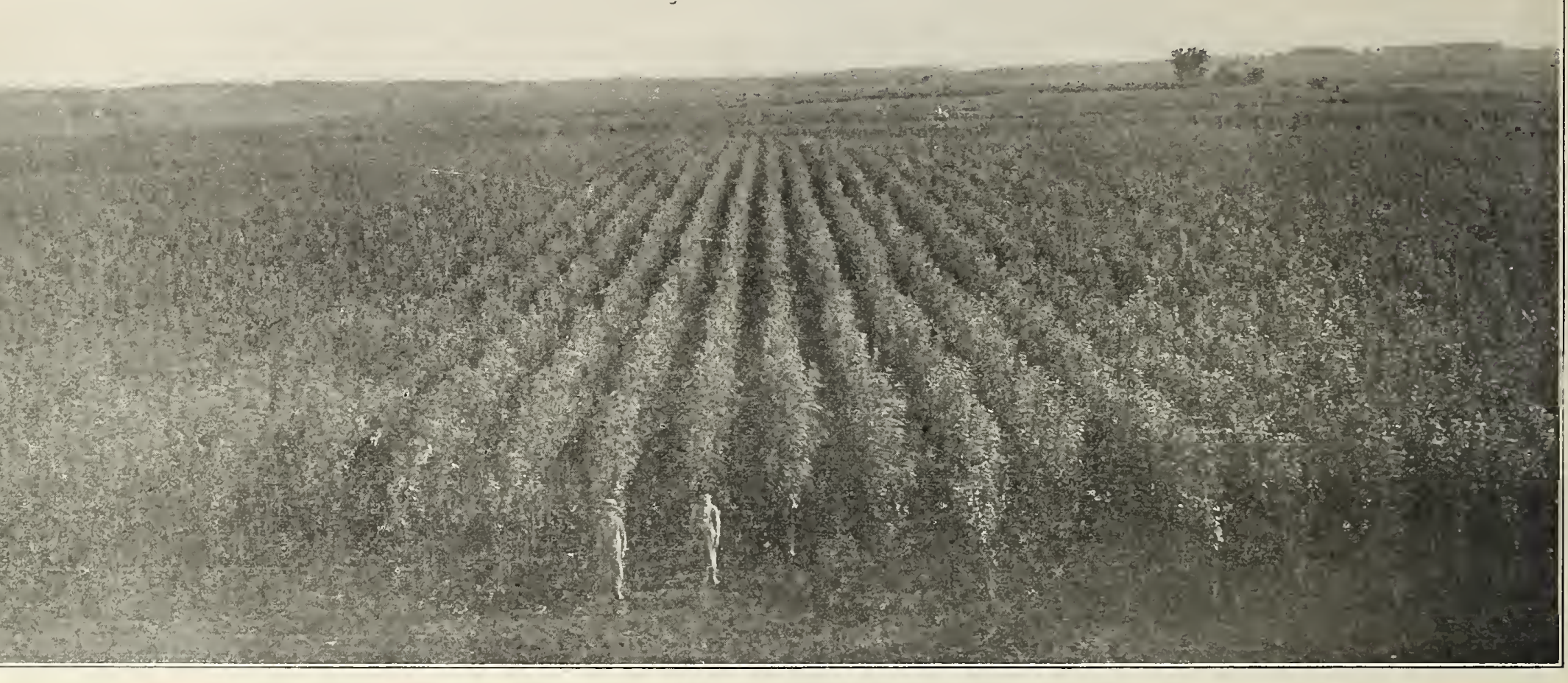

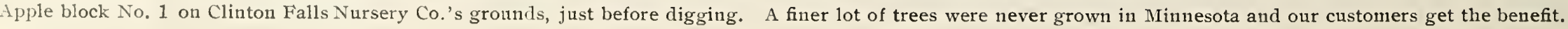




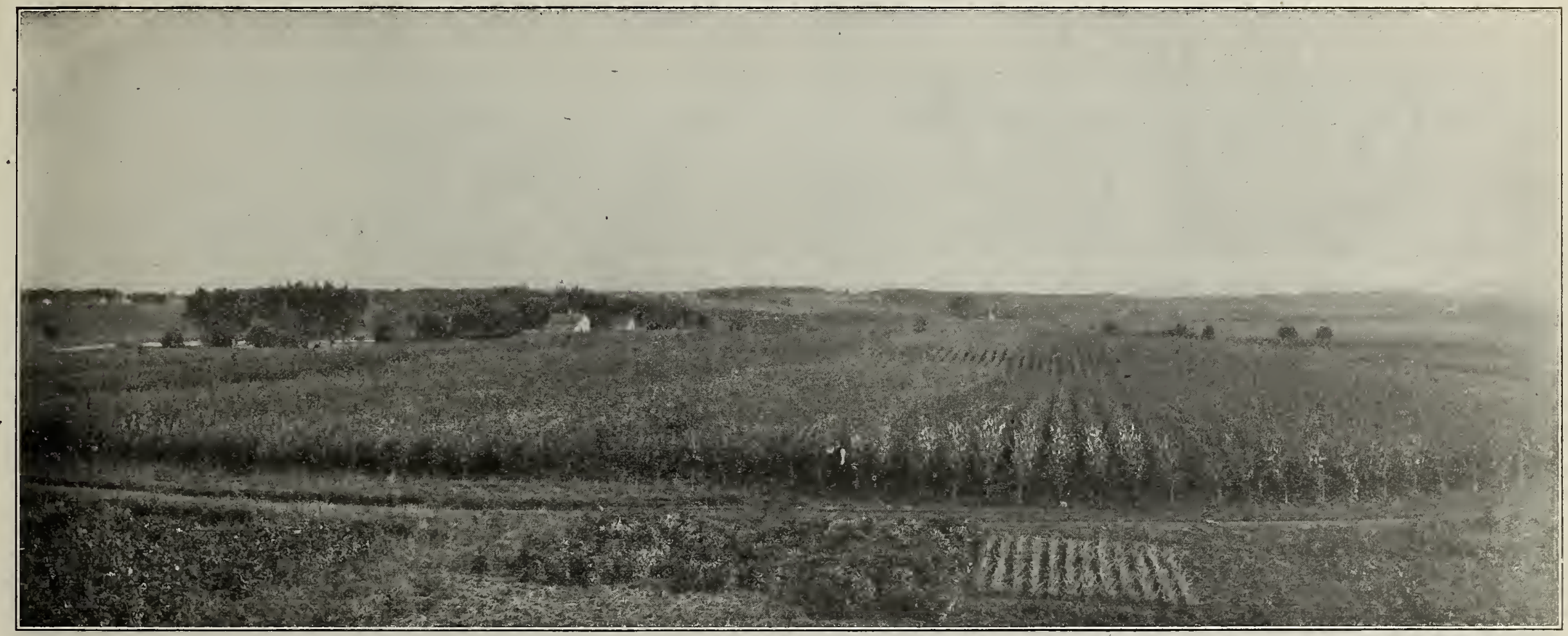

The above cut shows Apple Block No. 2 on Clinton Falls Nursery Co.'s grounds. We invite prospective buyers to carefully examine our stock before placing orders. We will convince you that our Nursery is headquarters for the Hardiest and Best grown Nursery Stock in Minnesota.

The followiug is a partial inventory of Stock growing in our Nursery: 1,800,000 Apple and Crab, 450,000 Plum, 58,000 Compass Cherry, 150,000 Currants, 20,000 Gooseherry, 150,000 Raspberry, 1,500,000 Strawberry, 500,000 Evergreens, 420,000 Sbade and Ornamental Trees, 5,500,000 Rooted Willows and Poplar Trees, 5,800,000 Seedlings and a large quantity of Shrubs, Roses and Herbaceous Plants. We are in position to supply you with stock that cannot be excelled. 


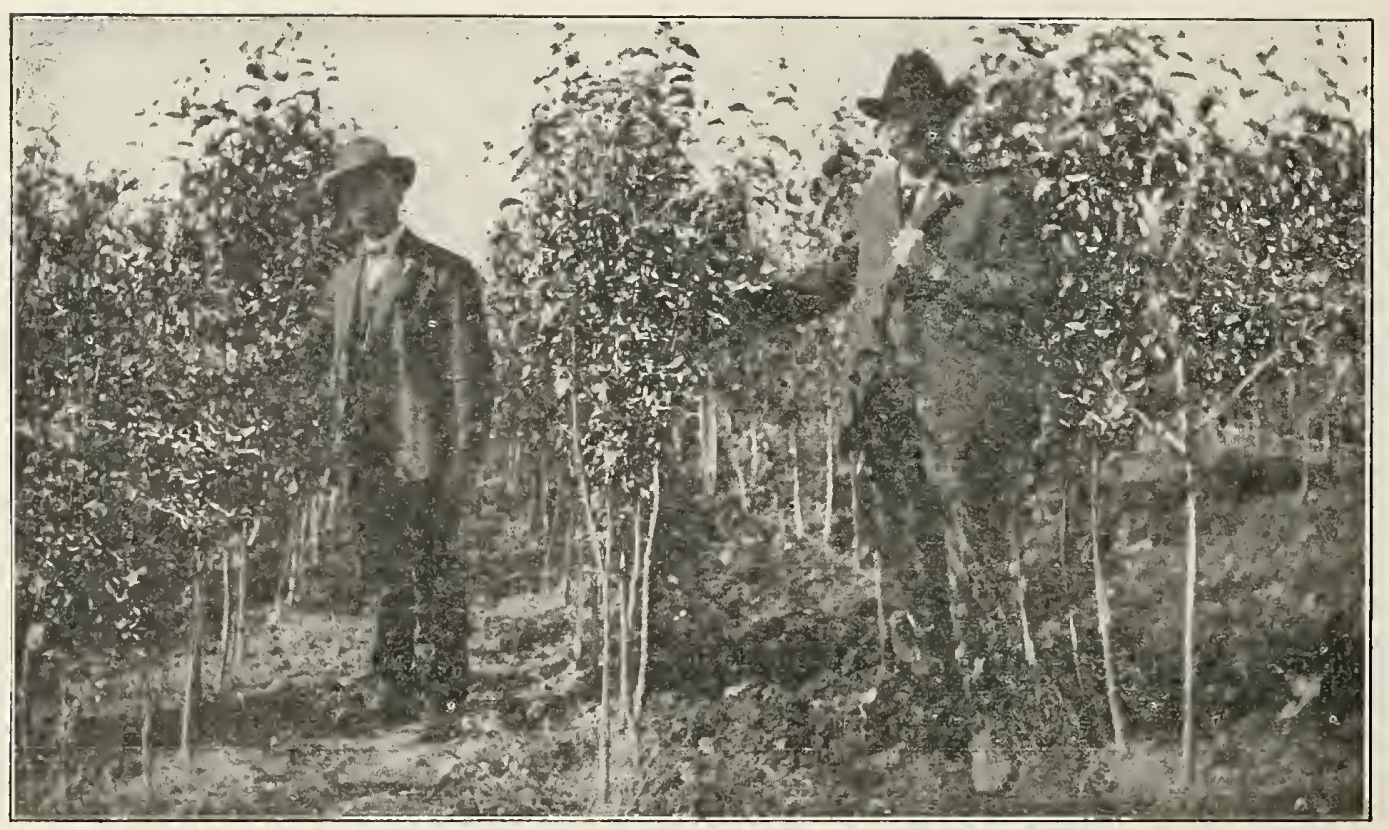

Visitors inspecting four year old apple trees on Clinton Falls Nursery Co.'s grounds. 


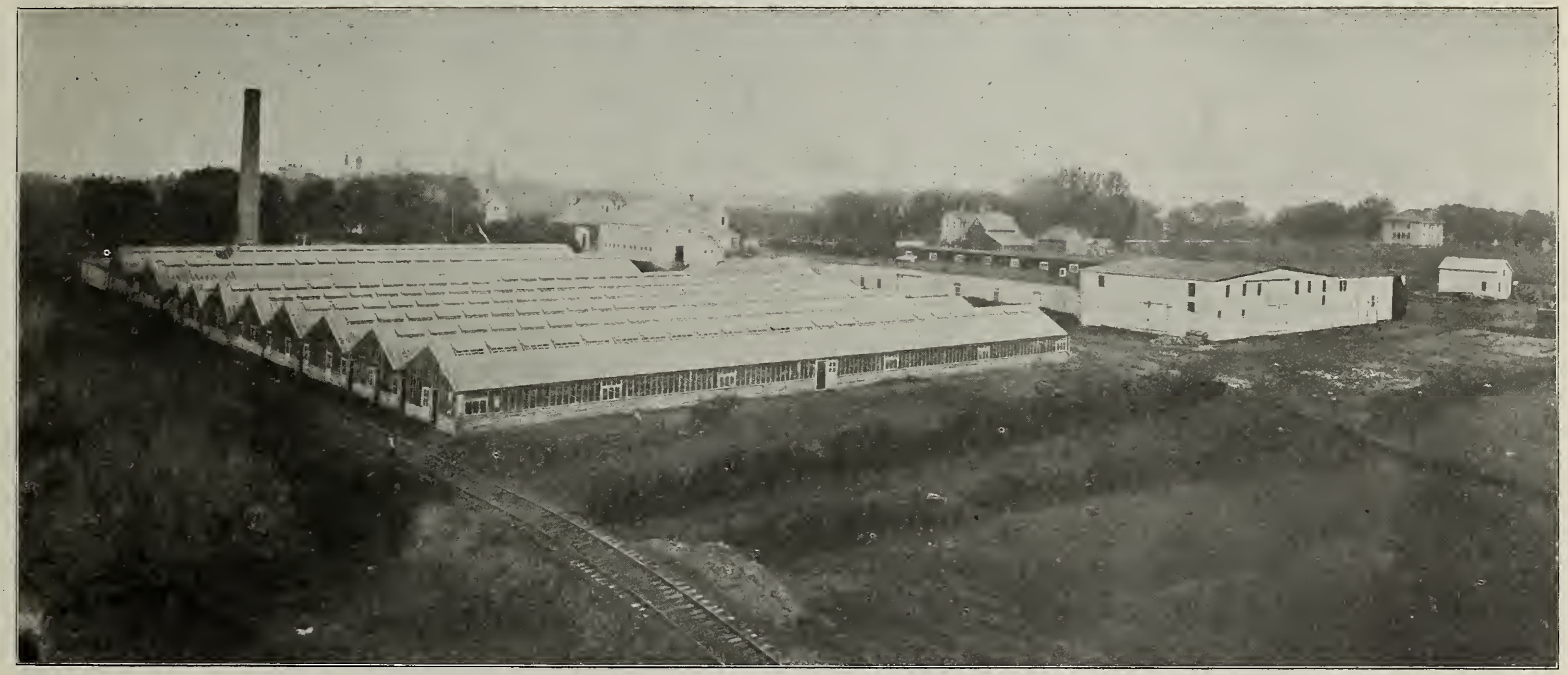

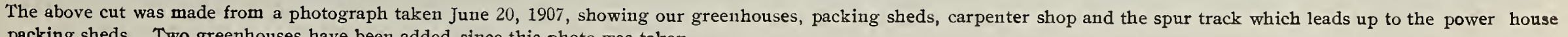
and packing sheds. Two greenhouses have been added since this photo was taken. 


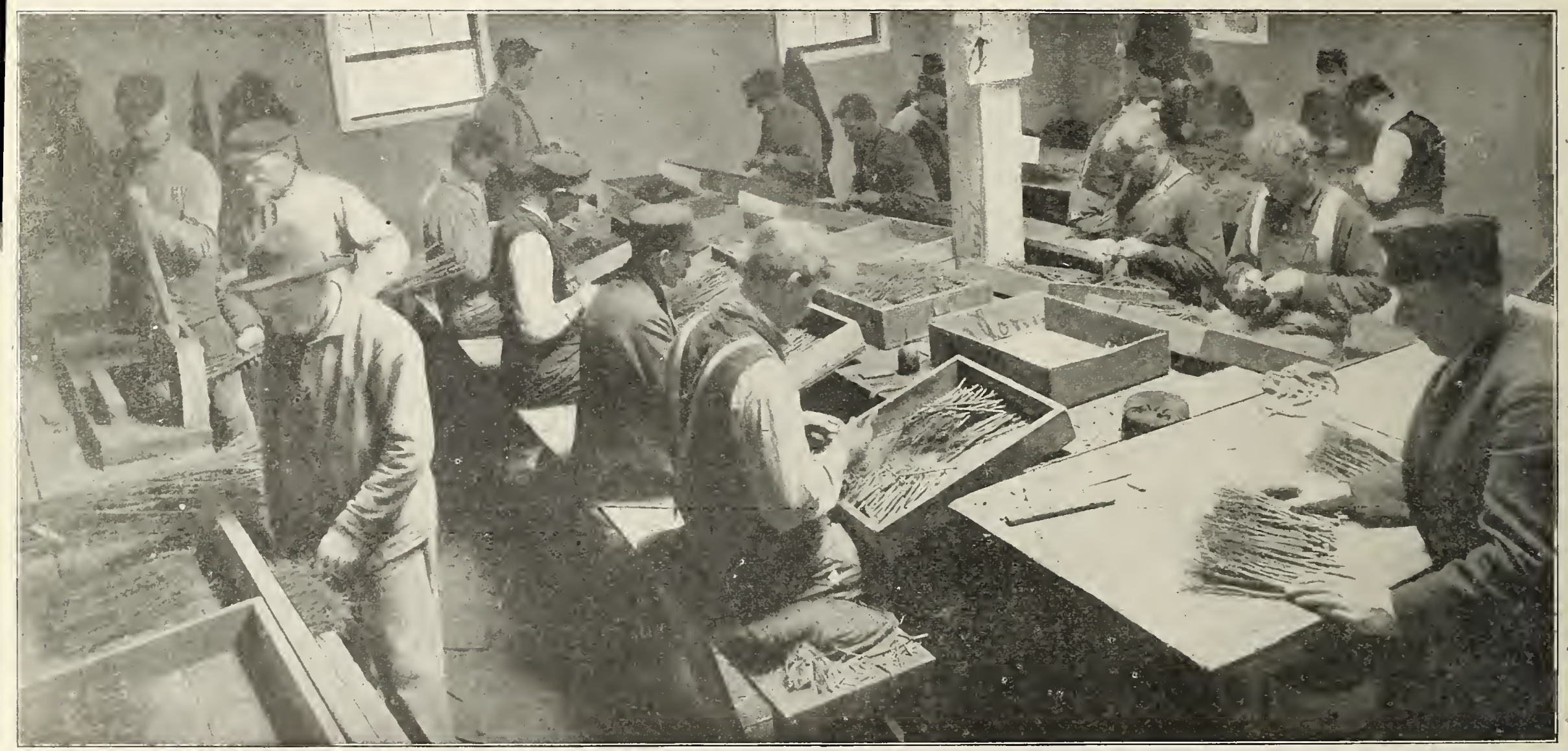

The regular force of skilled tree grafters and wrappers at work in the Grafting Department of the Clinton Falls Nursery Co., making 1,100,000 apple grafts. 


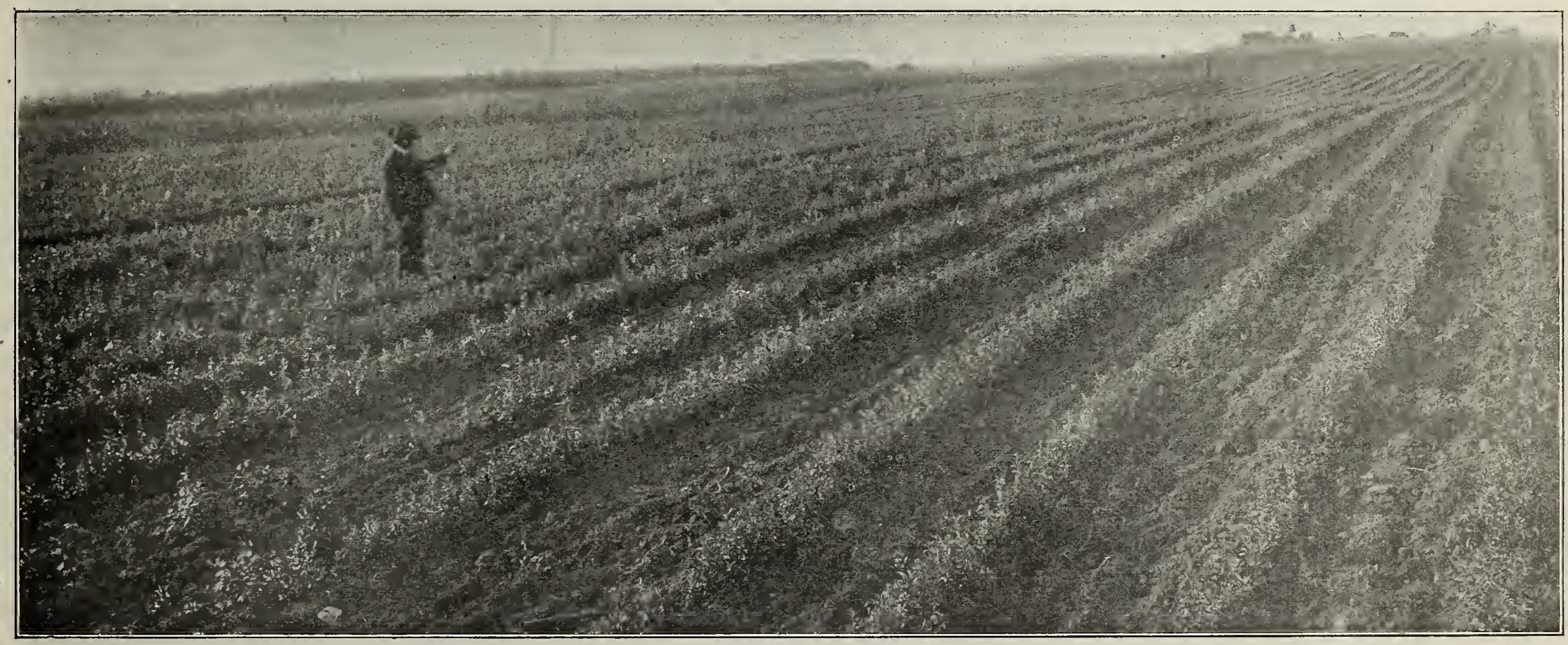



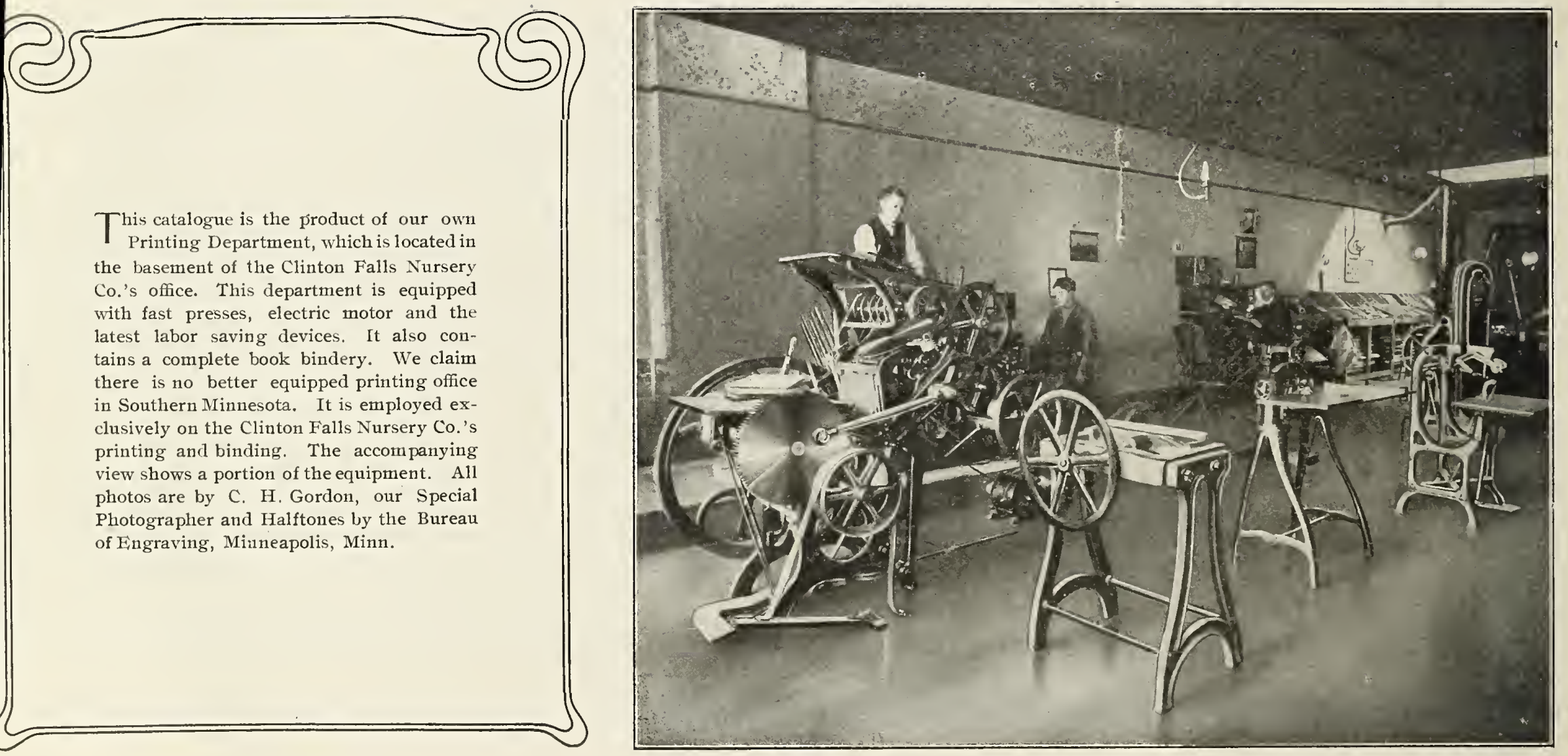


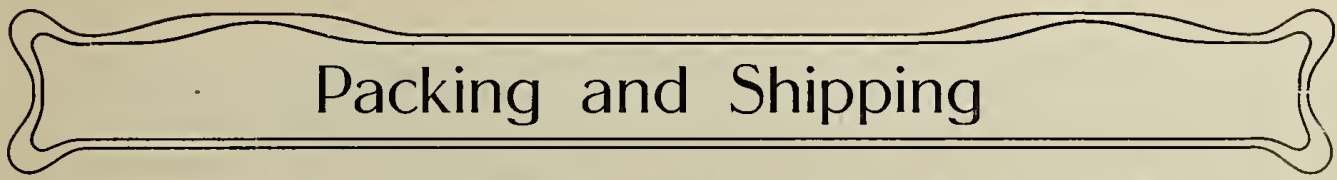

The accompanying cut on this page shows our method of packing trees and shrubs for shipment by-express. After years of experience in packing and shipping trees, we have learned that in order to lay goods down to our customers in good thrifty condition they must be correctly packed. Where trees go by express, they are packed in the following manner: The entire stock and branches of the trees are covered with rye straw and then firmly tied from top to roots, no branches or any part of the tree left exposed. After this is done the roots are thoroughly packed with damp moss, covered with burlap and sewed firmly, thus securing the entire bundle from becoming loose or shaken. Bundles packed in this way can be shipped any distance without injury to any part of the trees. When freight shipments are made, bundles are packed in large board boxes which have been lined with heavy paper; then the roots are entirely cotered with excelsior or bein lined with her pap dor it is necure trees from heating or becoming dry, it is necessary to pack them in this manner. Many companies use straw or litter in packing their trees. We find that the straw after being wet and packed in a tight box will, in many cases, especially in hot weather, heat, thus injuring the trees. The shingle shavings or excelsior after being dampened will retain moisture for ten days or more without becoming heated or dry, even in the hottest weather.

Shipping. Our shipping facilities are as good as could be desired, having direct access to points in all directions over three railroads, viz: the Chicago and Northwestern, Rick Island, and Milwaukee. Our nursery, situated as it is, seventy miles south of the 'Twin Cities, renders it convenient for us to make freight connections with all roads havins terminals at those points. We are therefore in a position to lay goods down anywhere to our customers in the shortest possible time. The Chicago and Northwestern R. R. Co. has built a spur from their road at Owatonna to our nursery grounds. This road greatly facilitates matters in our shipping department and is a very important addition to our equipment.

Shipping Seasons. We make two shipments each year, one in spring and one in Fall. Spring shipments are made between April 1st and May 10th, depending entirely upon the season. It is best not to ship too early, for trees should not be planted in any locality until the ground has warmed up sufficientlyto receive them. Our Fall shipments are made during the month of October and first part of November. In our locality and West and North of us, trees should not be planted in the Fall but buried in the ground and kept until Spring time to plant. Our Planters' Guide contains full instructions on plant-

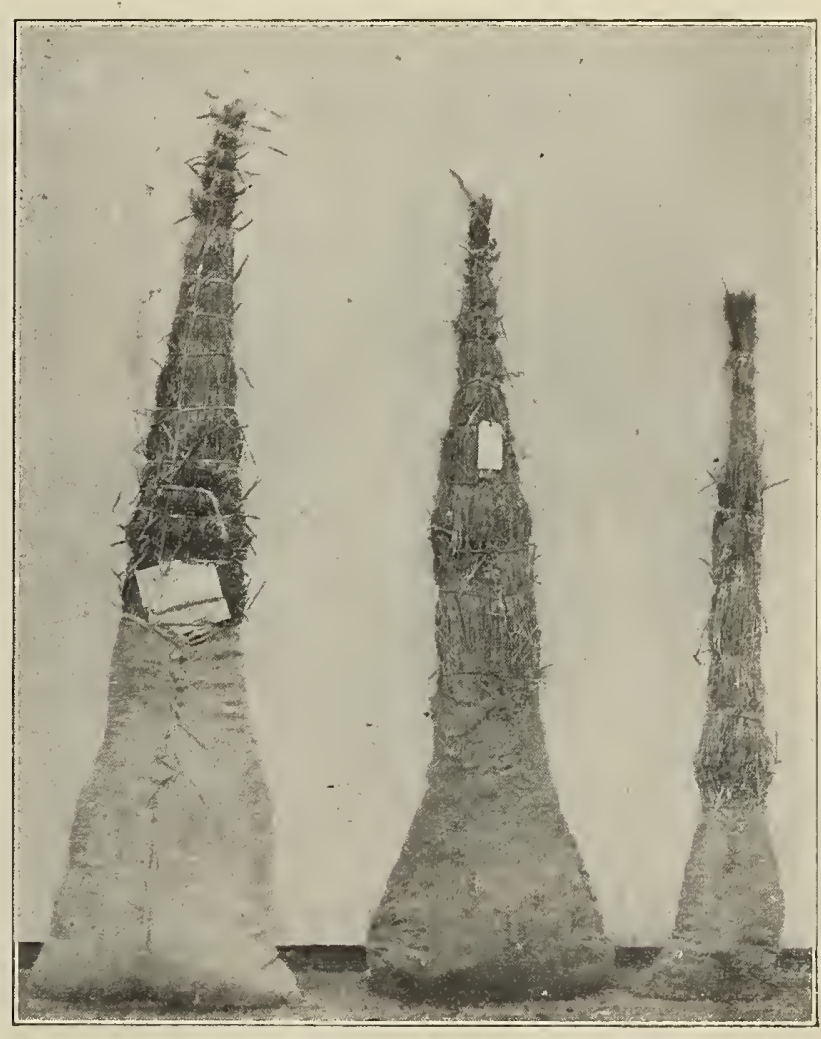

OUR EXPRESS BAIAES READY FOR SHIPMENT ing and caring for trees after being delivered. This will be furnished free of charge to anyone purchasing trees from us.

Our Guarantee. We guarantee the purity of all stock shipped out from our nursery, which means that all stock will be true to name and just as represented. In case of error on our part as to varieties and grade. we stand willing and ready at all times to correct any such errors. 

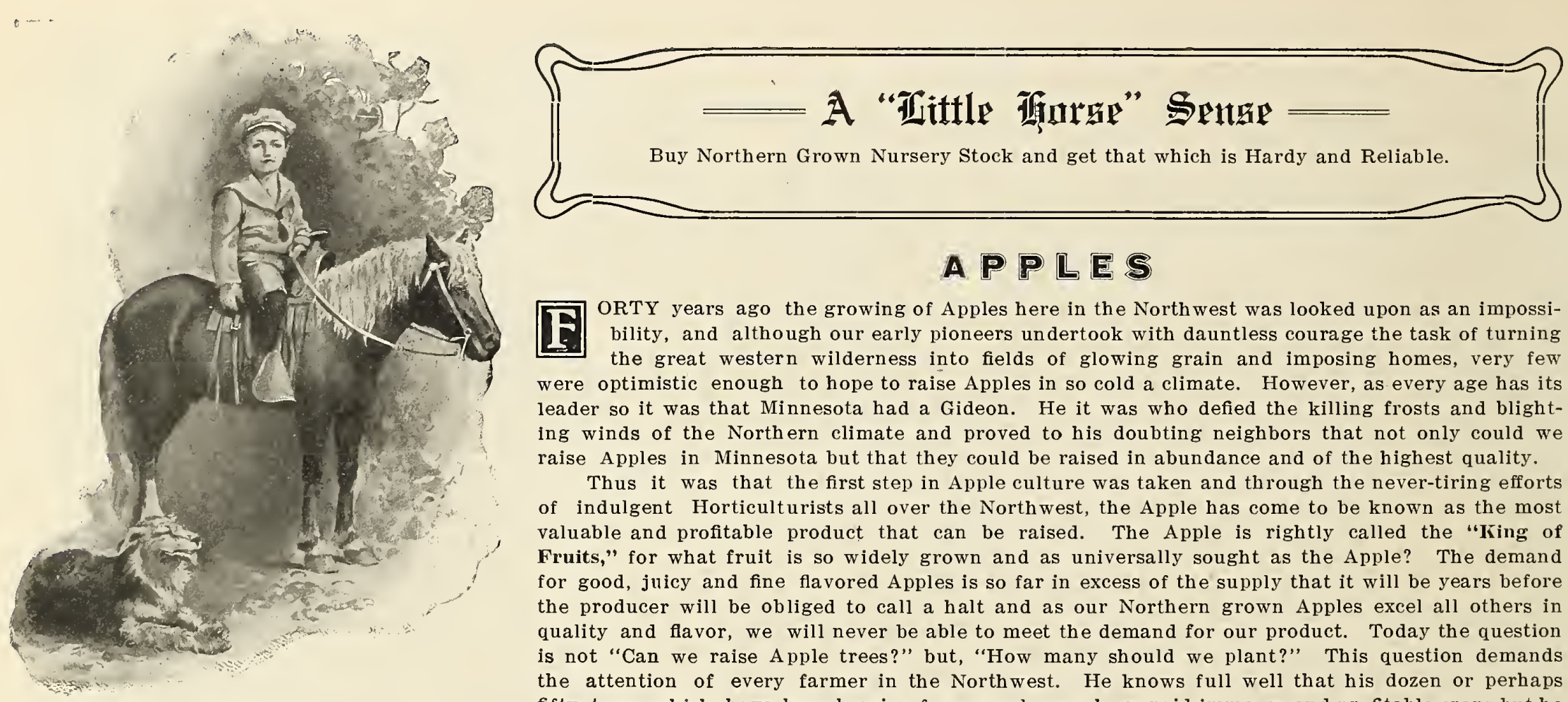

\section{$A P P L E S$}

ORTY years ago the growing of Apples here in the Northwest was looked upon as an impossibility, and although our early pioneers undertook with dauntless courage the task of turning the great western wilderness into fields of glowing grain and imposing homes, very few were optimistic enough to hope to raise Apples in so cold a climate. However, as every age has its leader so it was that Minnesota had a Gideon. He it was who defied the killing frosts and blighting winds of the Northern climate and proved to his doubting neighbors that not only could we raise Apples in Minnesota but that they could be raised in abundance and of the highest quality.

Thus it was that the first step in Apple culture was taken and through the never-tiring efforts of indulgent Horticulturists all over the Northwest, the Apple has come to be known as the most valuable and profitable product that can be raised. The Apple is rightly called the "King of Fruits," for what fruit is so widely grown and as universally sought as the Apple? The demand for good, juicy and fine flavored Apples is so far in excess of the supply that it will be years before the producer will be obliged to call a halt and as our Northern grown Apples excel all others in quality and flavor, we will never be able to meet the demand for our product. Today the question is not "Can we raise Apple trees?" but, "How many should we plant?" This question demands the attention of every farmer in the Northwest. He knows full well that his dozen or perhaps fifty trees which have been bearing for several years have paid immense and profitable crops but he

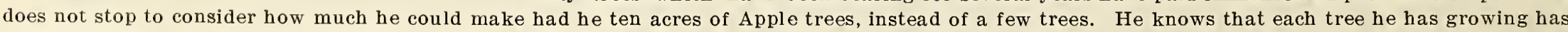

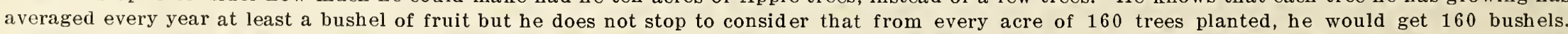

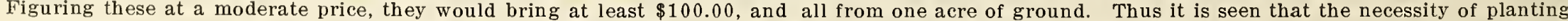

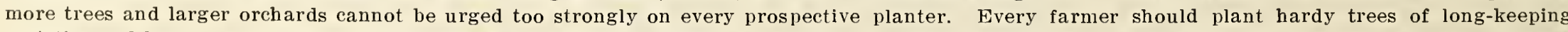

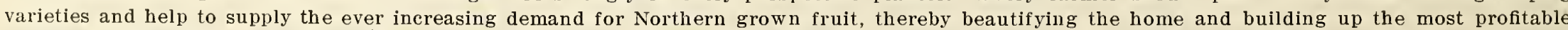

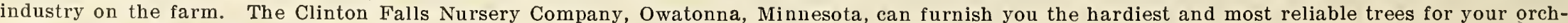
ard Every Tree Guaranteed to Grow. Our agent will call on you. 


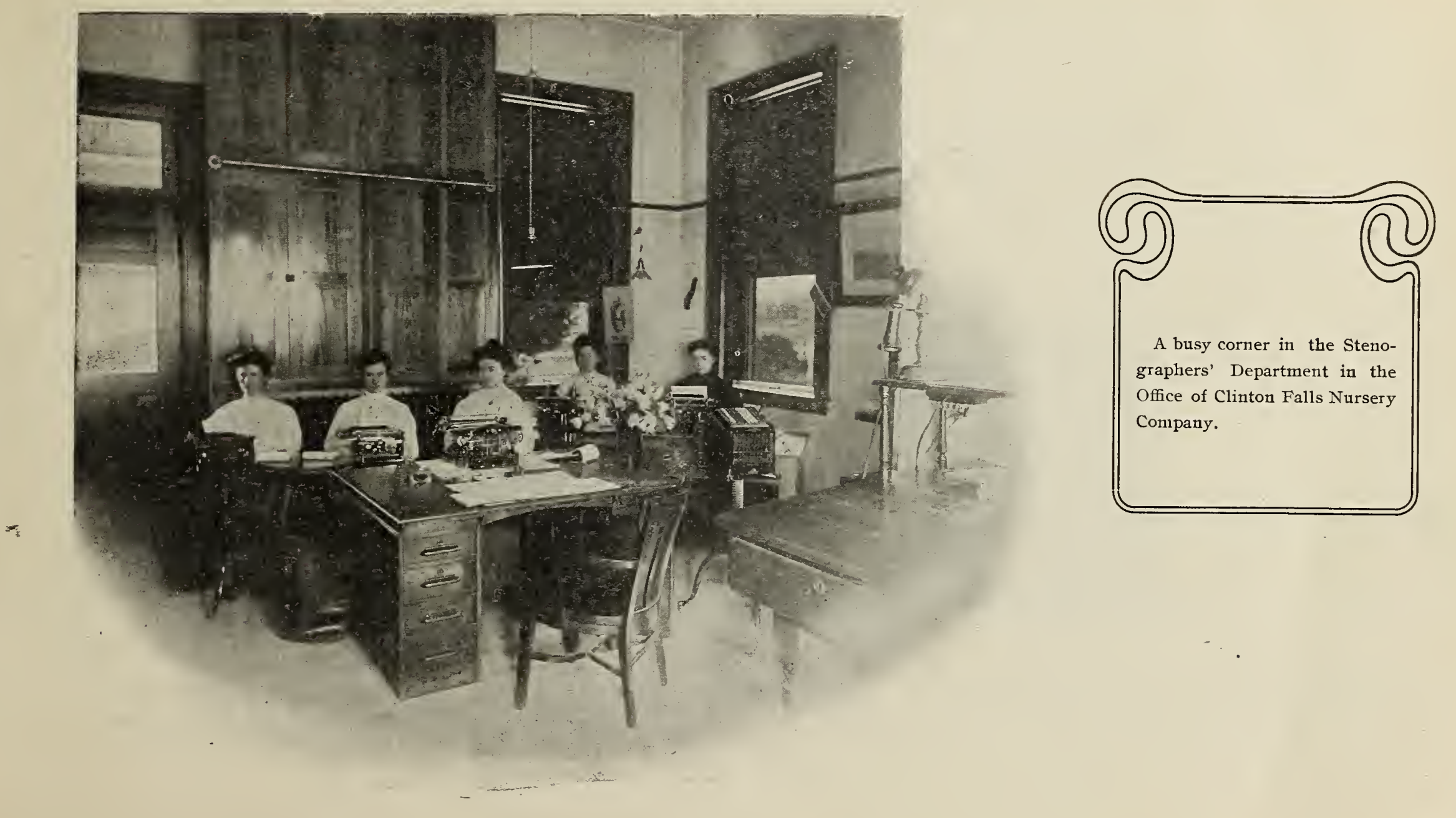




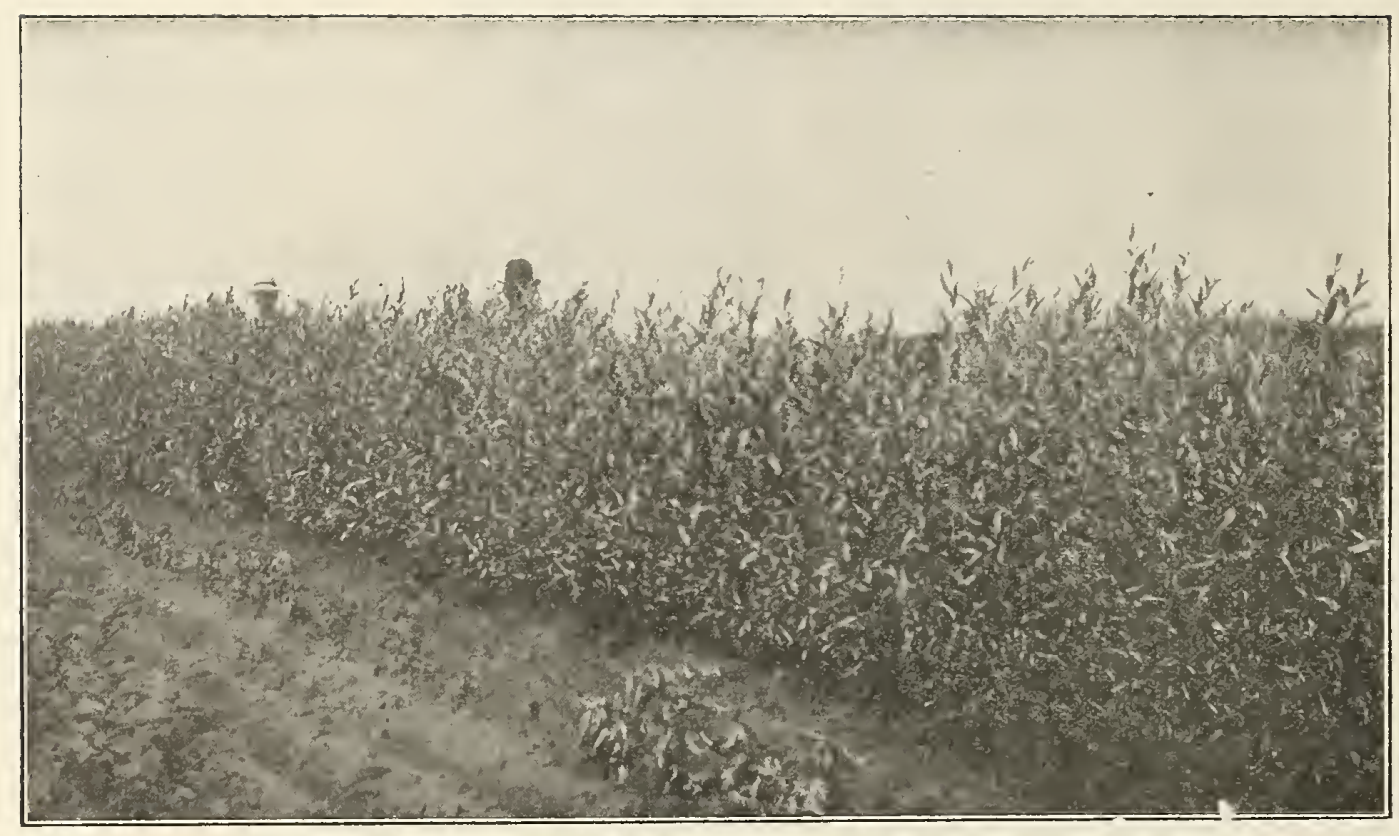

Golden Willow Hedge on Clinton Falls Nursery Co.'s grounds, showing four months growth after being cut to ground. 


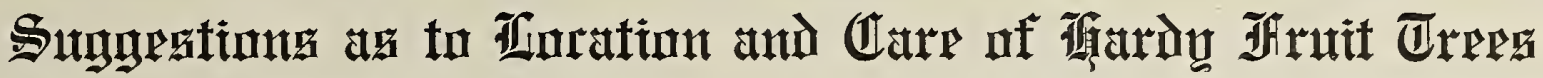

Location. The best is a high Northern exposure. If you do not have such a location, select the varieties best adapted to the one you have. Some of the best orchards in the state are on a Southern exposure, but the soil is good and their care the best. High ground is very desirable.

Soil. A clay sulssoil is the best. It prevents drying out. If not a clay subsoil, mulch heavily to keep the ground cool and moist.

Laying Out Grounds. To lay out grounds properly for an orchard set stakes five feet long around the outside, the proper distance apart, then set a row each way through the middle and in line with the outside stakes. Then dig the holes and set the trees by sighting through to the stakes. In this way the trees will be in perfect rows in all directions.

Where a straight row in the garden is required, use a long two-inch rope, tie each end to a short handled dibber and thrust them into the ground, stretching the rope very tight, and walking upon it will leave a satisfactory mark to set by.

Planting. Before planting, cut trees and plants back vigorously and trim off injured roots. Mud the roots well in thick mud, and plant before it has time to dry. Never expose roots or tops to sun or wind before planting. Holes for trees should be large and deep. Set apple trees from 12 to 18 inches deeper than when growing in nursery.

How to Set a Tree or Shrub. Mind this rule and you will succeed. After the hole is dug and the tree or plant stood in place, sift some fine, moist, rich dirt among the roots just enough to cover so the hoot will not injure them, then with the foot and all the strength you can command, stamp the earth down until it is solid, then fill in a little more dirt and repeat the stamping until the hole is nearly full; then fill the rest of the hole with loose dirt and leave it with the soil pitching toward the tree fom all directions. If it is properly filled you cannot pull it up. The same general rule applies to everything, from a strawberry to a shade tree.

First, do not expose them. Second, mud the roots; it is better than pouring on water. Third, set firmly, so you cannot pull up the tree or plant without spoiling it. Fourth, leave the ground loose on top and slanting toward the tree or plant.

Cultivation. It is always best to cultivate. Keep the ground loose on top and clean. Do not cultivate deep. Cease cultivating trees in July, and allow them to ripen. If the ground is dry (in October) after the growth has ceased, cultivate lightly, and make a dust blanket to prevent the evaporation of moisture and to appropriate any moisture that falls.

Mulching. Where you cannot cultivate, mulch thoroughly; put it on thick for six feet around the tree, so as to keep the ground moist and cool, but do not let it touch the tree, as it is liable to heat and injure the bark. It has been found an excellent thing to mulch Raspberries and Blackberries with green clover; cut it when in full bloom and spread it on two to four inches thick and twelve to eighteen inches on each side of the row. This serves to keep the ground cool and is the cheapest fertilizer known.

Pruning is best done in Jnne. Prune tops and branches severely, and roots moderately, when planting, but afterward only prune sufficient to obtain or preserve the desired form. A low spreading top is preferable.

Sun-Scald. We give the methods most in favor to prevent sun-scald. First, lean the tree toward the South, so that the rays of the sun at mid-day will not focus on the body of the tree. Secondly, wrap the body with burlap, wire screen, news papers torn in strips, or tree protectors; a string at top and bottom will hold it securely. This method also prevents injury by rabbits. For mice clean away all straw or dry grass and weeds and put a little fresh earth around the base of the tree. Poison rabbits with arsenic in sweet apples, and for mice poisoned corn.

Keeplng. Fruit will keep best in a cool dry room. Apples should be barreled ap tight. 


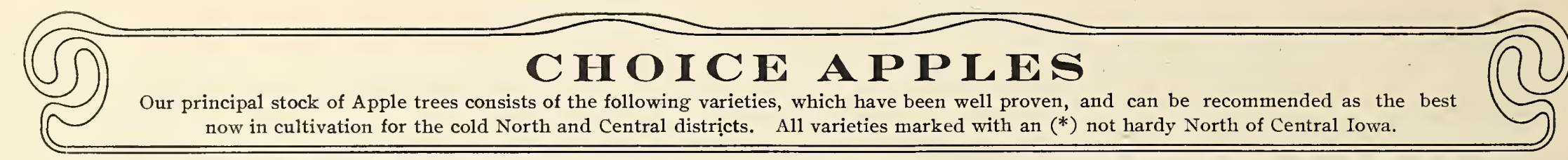

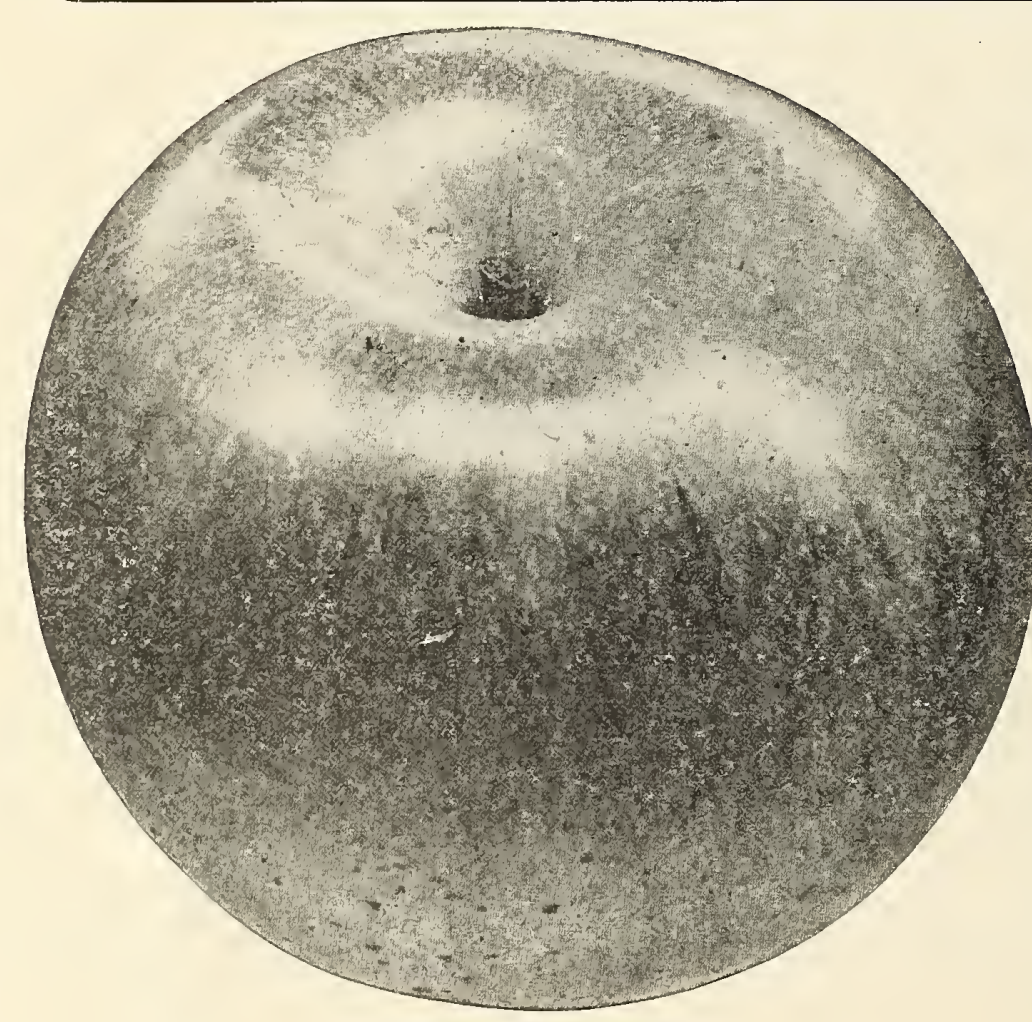

DUCHESS OF. OLDENBURG

Anisim. Origin, Russia. Season, November to January. Tree spreading and a prodigious bearer; unusually free from blight and about equal with Wealthy in hardiness. Fruit medium to small, roundish; color, greenish nearly covered with dark red, over which is a bluish bloom; flesh white, juicy, fine grained, pleasant sub-acid. Beautiful when well ripened. Its hardiness and productiveness have given it considerable popularity for the home orchard.

*Arkansas Black. Large, red, fine quality, long keeper.

*Ben Davis. Origin, Kentucky. Season, January to April. (Known also as Kentucky Red, New York Pippin, etc.) Vies with the Baldwin as a profitable commercial variety in many sections; quality not so good but a better bearer and keeper. Tree, very vigorous and hardy in the Central States; has also been fruited successfully in Minnesota but is not considered profitable so far North. Fruit large and handsome, brightly striped with red; flesh of medium quality, variable in flavor. It is remarkably fruitful and heavily planted in Missouri, Arkansas, etc.

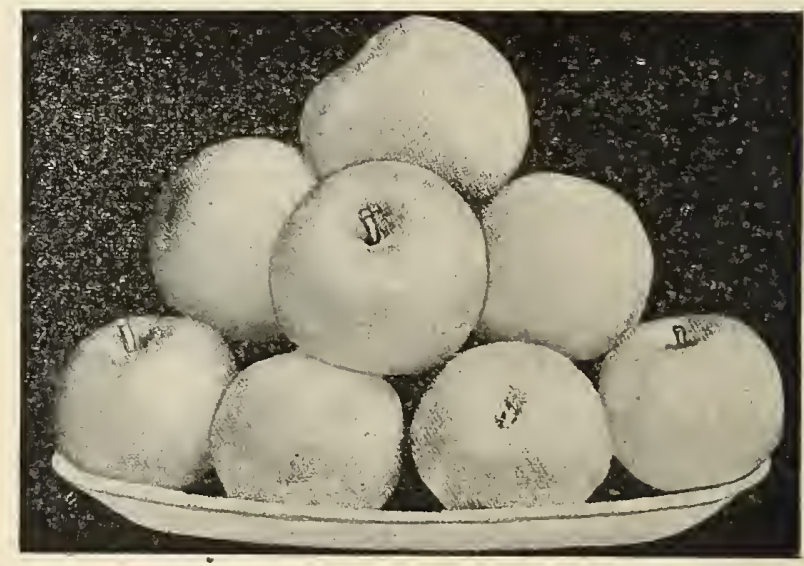

NORTHWESTERN GREENING (One-fifth actual sire) 


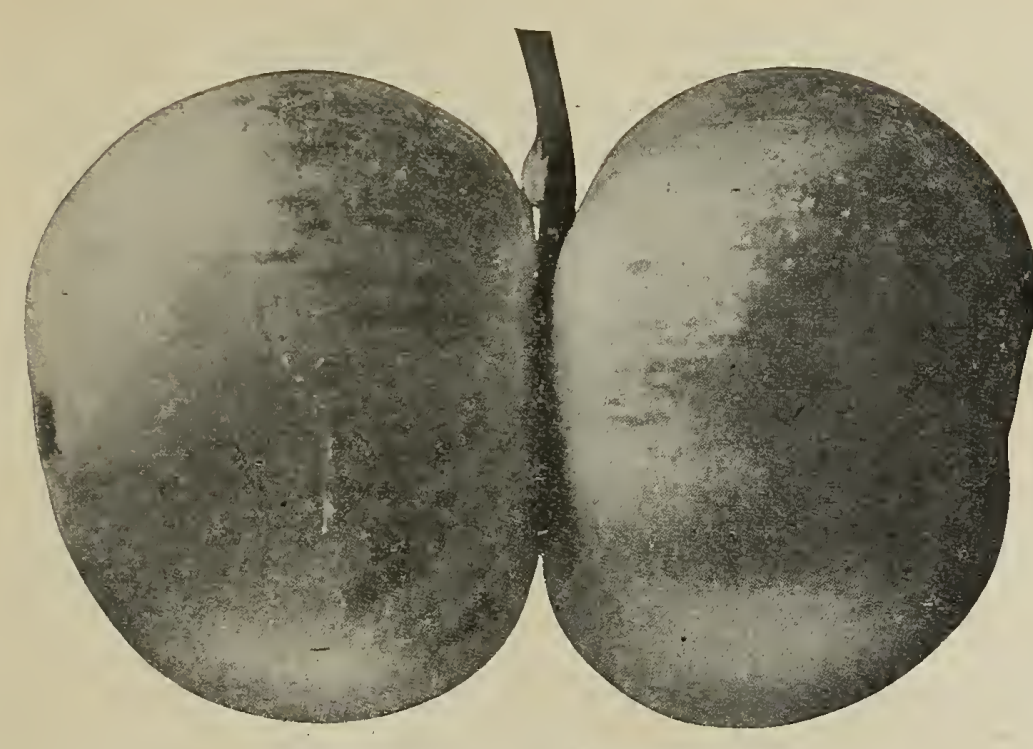

WOLF RIVER (About one-half natural size)

*Baldwin. Origin Massachusetts. Season December to March. The great commercial late winter keeper of the Eastern States. Almost too well known to need description. Tree a vigorous, open grower, upright in tendency and very productive where hardy. Fruit large, roundish, deep red; flesh rich, crisp and juicy. In New Fingland, New York, Ontario and Michigan is regarded as one of the most popular and profitable varieties for either table or market, where it holds about the same commercial place as the Ben Davis in the Central States. Not hardy North of Central Iowa.

* Bailey Sweet. Origin New York. Season October to December. An old, choice variety, not generally hardy in the North and has not received much attention even in those sections where it is better known. It has, however, been fruited successfully as far North as Southern Minnesota and South Dakota. Fruit large, conical, irregular, greenish yellow with dull red stripes and russet dots; flesh yellow, moderately juicy, firm, sweet and very good.

*Benoni. Massachusetts. August. Medium size, red; tender, juicy, rich.

Charlamoff. Origin Russia. Season Angust and September. Tree spreading, vigorous and productive. Fruit above medium to large; light yellow to crimson stripes; flesh white, fine grained, pleasant flavor, often stained with red next to skin. A little later in season than Duchess.

Duchess of Oldenburg. (Russian.) Tree a moderate grower, upright in habit, bark dark in color and very smooth, fruit extra size, pale green shading to white, beautifully striped pink, tender juicy, tart, highly esteemed for market or domestic use; an immense bearer. This is the standard Apple for hardiness, and is doing well more universally throughout the Northwest than any of the old varieties. August and September.

*Eary Harvest. America, August, Medium; pale yellow; excellent flavor.

*Fameuse. (Snow) Medium, deep crimson, flesh white, of best quality.

*Gano. An improved Ben Davis, nearly covered with deep dark red.

* Grimes' Golden. Good size, yellow, of highest quality, very productive.

Hibernal. Origin, Russia. Season, November, December. (Synonyms: Lieby, Recumbant, Juicy Burr, Silken Leaf, etc.) This variety represents what is probably the hardiest type of the Russian race; adopted by many prominent horticulturalists as a standard of hardiness. Tree, sturdy, vigorous, very spreading and productive. Fruit large to very large, irregular; greenish yellow with dull bronze red on sunny side; flesh, acid, juicy, very good for cooking. Succeeds in most ex-

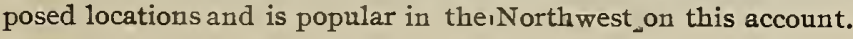




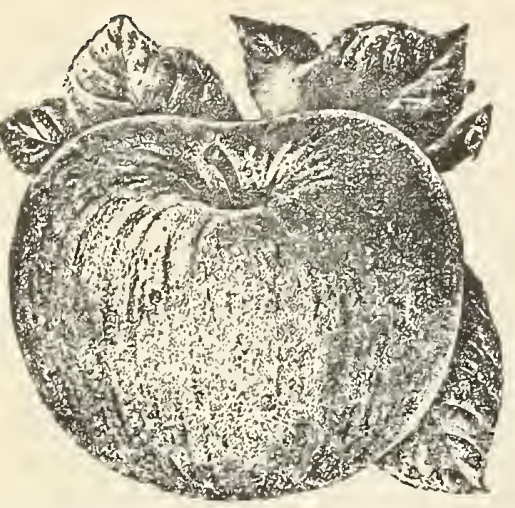

WEALTHY (About one-half natural size) lush of brownish red; flesh hard, mediug

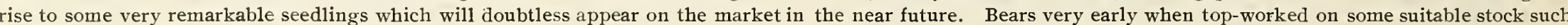
as Hibernal or Virginia.

*Maiden Blush. New Jersey. September and October. Pale yellow with red cheek; tender and pleasant but not highly flavored.

*Mammoth Black Twig. Large, dark red, hardy and productive; vigorous.

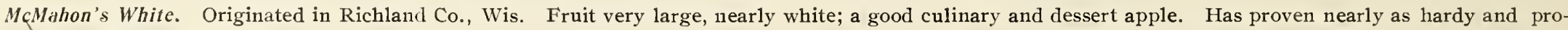
ductive as the Duchess.

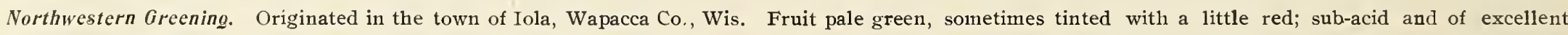
quality. March and April.

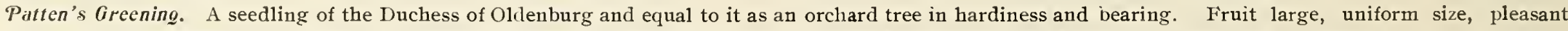
acid, equally good for eating and cooking. It ranks as the best all around tree for Minnesota and the Dakotas, where it will keep until February.

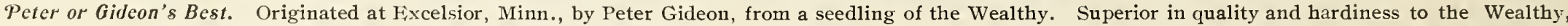

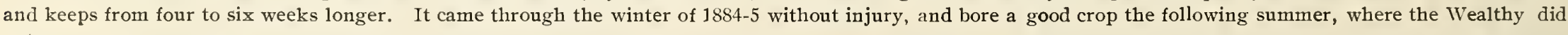
not.

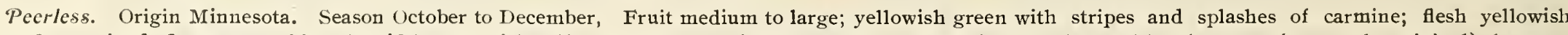

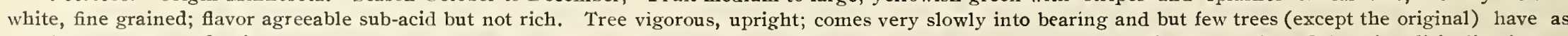

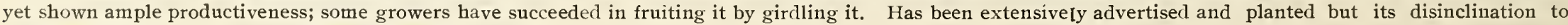
bear has excluded it from an important place in the list. 
Peewaukee. Origin, Wisconsin. Season, December to March. Tree spreading, round topped and vigorous. Doing well in Eastern Wisconsin, but has not proven especially desirable in Central Minnesota, although it has been succesful in favorable locations. Fruit large, yellowish green, striped and shaded with dull red, overlaid with a bluish bloom; flesh yellowish, rather coarse grained, firm, juicy; flavor sub-acid. Originated by crossing the Duchess of O1denburg with Northern Spy pollen. It is reported a good regular bearer and a profitable variety where it is hardy.

Phoenix No. 50. From scions sent the Superintendent of the Owatonna Experimental Station eighteen years ago from Illinois. The tree has proven to be perfectly hardy, a strong grower and bears large, green Apples; flushed on sunny side, good quality. Season, December to February.

*Red Astrachan. Origin, Russia. Season, July and August. First imported into England with the White Astrachan from Sweden in 1816. Tree, upright, spreading, vigorous growth; an early and abundant bearer. At one time was considered as belonging to the standard list, but not entirely hardy in extreme sections, and like many other varieties is subject to blight. Fruit above medium; greenish yellow, almost covered with mottled and striped crimson; flesh, white, crisp, juicy, brisk acid; good.

*Rhode Island Greening. Origin, Rhode Island. Season, December to March. Fruit large and handsome; smooth dark green overspread with yellow; flesh tender, rich, rather acid but highly flavored and excellent. Has long been popular in the Eastern States as a dessert apple and also for cooking. Tree vigorous and spreading; a heavy and constant bearer. One of the most widely disseminated of the old varieties and where hardy will never cease to be grown for table and market.

Scott's Winter. A Vermont seedling, profuse bearer; fruit medium size; thickly striped with bright red. Quality most excellent

*Salome. Long keeper, annual bearer, medium and uniform size; good quality.

*Sops of Wine. An oblong, dark crimson Apple of medium size; flesh juicy, sub-acid, stained with red. The tree is a vigorous grower and is exceedingly fruitfnl. August.

* Tolman Sweet. Origin, Massachusetts. Season, December to March. One of the most popular of the old Eastern varieties and where hardy is one of the most extensively grown of the sweet Apples, Tree is vigorous, upright,

THERE IS A VAST DIFFERENCE IN THE VALUE OF THESE TREES.

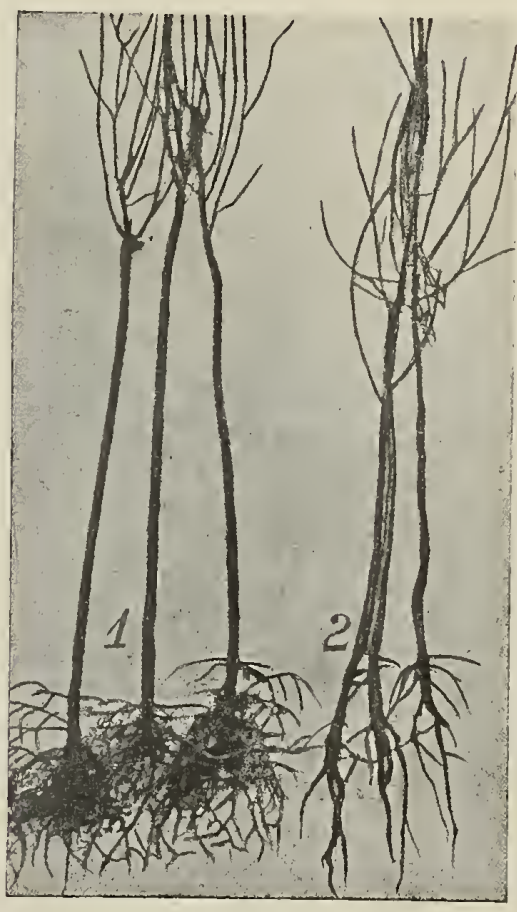

No. 1 well rooted trees, such as we furnish our customers. No. 2 , poorly rooted trees, often sent out by narserymen who sell cheap stock. 


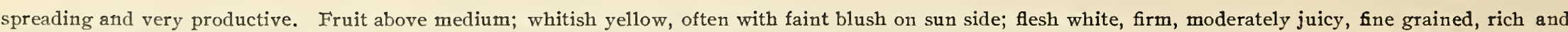
sweet; quality excellent for a sweet apple. Keeps easy under ordinary conditions and is an excellent baking apple.

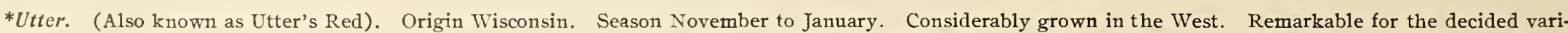

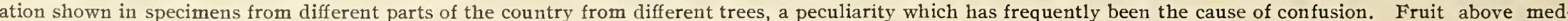

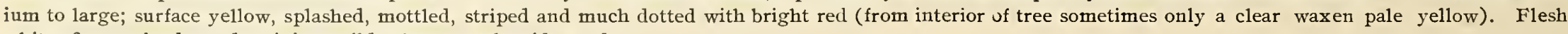
white, fine grained, tender, juicy, mild, pleasant sub-acid, good.

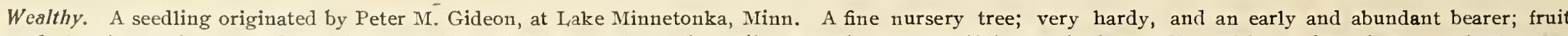

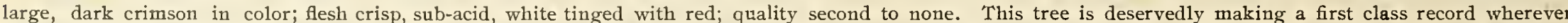

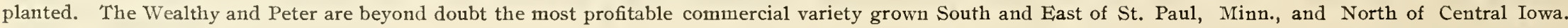
November to February.

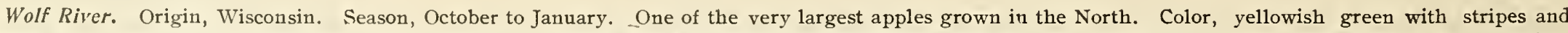

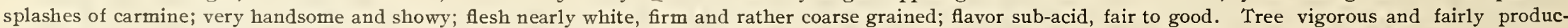

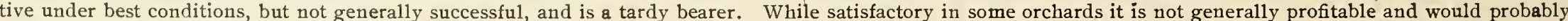
pass out of notice except for its magnificent size and coloring.

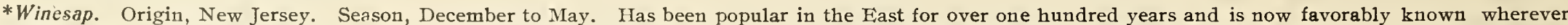

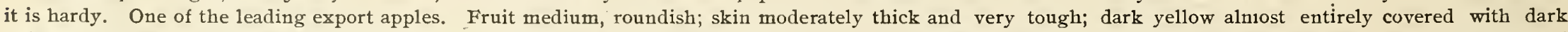

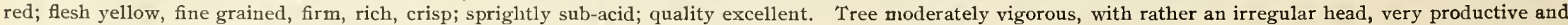
an early bearer. The shipping quality of the Winesap makes it a very profitable variety, commercially.

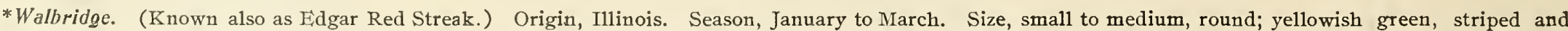

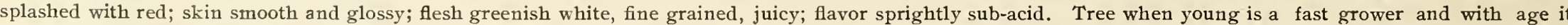
becomes a very heavy bearer alternate years. The fruit is of the best quality for home use, but rather too small to make it a profitable commercial variety.

*York Imperial. (Johnson's fine Winter.) Medium to large; yellow, shaded red; firm, juicy, sub-acid. An excellent shipping apple.

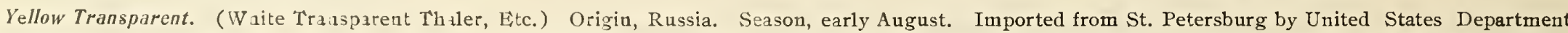

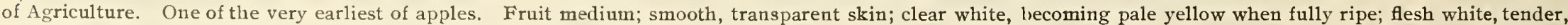

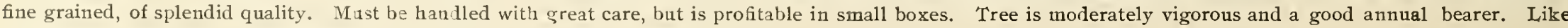
others of its class, it is a bad "blighter" and for this reason is sparingly planted. 

superior quality of fruit and are of fair size. The following are the most valuable varieties.

Early Strawberry: Tree a good grower, symmetrical, hardy; fruit size of Transcendent, red-striped, crisp, juicy, excellent for eating. Season August.

Hyslop. An old and popular crab. A good grower and very hardy; fruit larger than Transcendent; deep crimson in color; flesh white, tinged with red; an abundant bearer. Season, September and December.

Minnesota. Hardy; a medium grower; fruit larger than Golden Russet; light color with blush on sunny side; quality excellent. In size, beauty and keeping qualities the best of the winter varieties. January and February.

Orange (Hybrid). Origin, Iowa. Season, October. A beautiful and very useful crab that should be found in every orchard. Fruit large, even, light orange

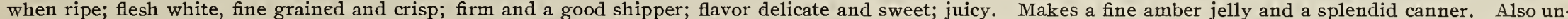

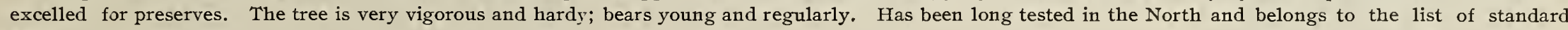
sorts.

Siberian (Crab). Fruit small, round; flavor sour and acid--still is excellent for jelly though too small for market purposes. Tree is a free grower and hand-

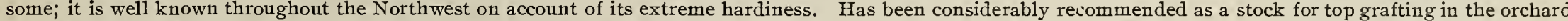

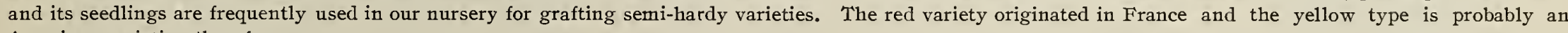
American variation therefrom.

Sweet Russet. Tree a fairly good grower and of good form. Perfectly hardy; fruit large, round and conical, green russet with faint blush. Very rich and sweet; the best of its season for eating and cookiug. Season, August and September.

Tetofsky. Origin, Russia. Season, August. One of the earliest if not the earliest apple to ripen in the Northern states, and has been very popular on that ac-

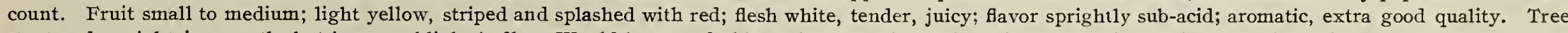

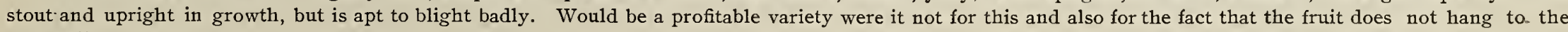
tree well.

Transcendent (Crab). Origin, Russia. Season, September. Fruit medium to large; color brownish yellow with a blush of carmine; flesh firm and crisp, yel-

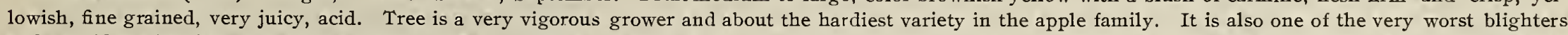

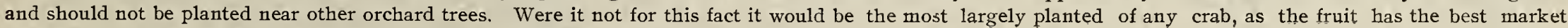
qualities. Of most value in the extreme North and somehow blights less in that section. 
Virginia (Crab). Origin, doubtfu1, but probably Iowa. Season, Septemder. Fruit, medium, round; color yellow and blush red, somewhat striped; flesh yellow, crisp; flavor acid, sometimes bitter. Tree vigorous, large, spreading, hardy, moderately productive, seldom blights badly. Has been recommended as a stock for orchard grafting where a vigorous foundation is desired, and is probably one of the best for this purpose. Decidedly different from Hewe's Virginia and should not be confounded with it.

Whitney. One of the largest; glossy green, splashed carmine, firm, juicy, pleasant, great bearer; excellent for cider. August.

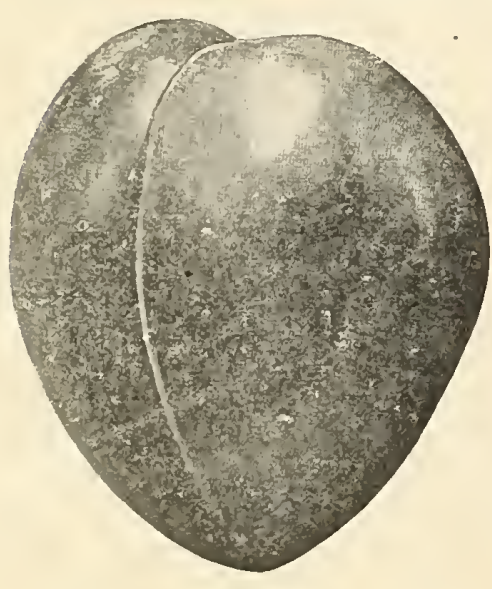

WICKSON

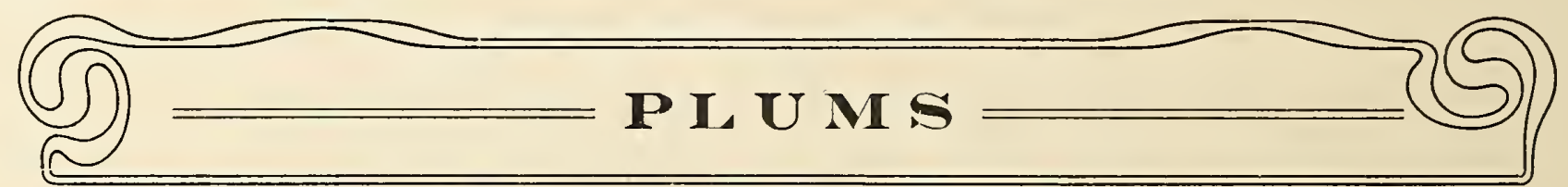

the wild state Plums that can produce fine fruit abundantly are found in groups or clumps. Single trees removed from such groups have been found to be unfruitful, until fertilized by neighboring trees. For this reason we advise to plant in groups or clusters. To form a group of trees, mark out a plat of ground 40 feet square according to the diagram here given, and set a tree at each dot, thus bringing the trees in close proximity to each other. As a result the pollen will be conveyed from tree to tree and fertilization ensue. Another important item is to set different varieties near each other, so those kinds that have imperfect blossoms may become fertilized by the pollen from trees with perfect blossoms.

Abundance. (Botan). One of the oldest and best known Japanese varieties; hardy and productive. Fruit large, lemon yellow, with heavy bloom; good quality. August. Not hardy North of Central Iowa.

Burbank. The best and most profitable among growers for market; ripens from ten to fifteen days after Abundance.

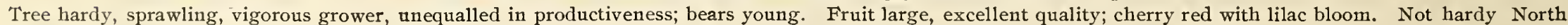
of Central Iowa.

Cheney. Fruit averages quite large; flesh firm, free from astringency, and valuable for market or dessert use.

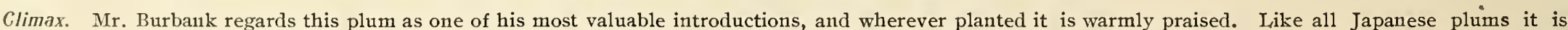

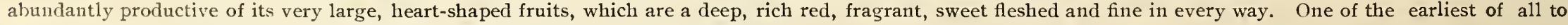
ripen. The tree is strong, thrifty and hardy. Not hardy North of Central Iowa.

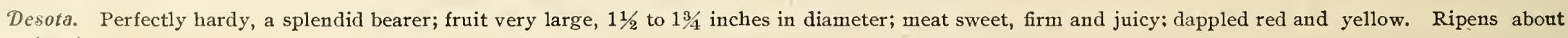
September 1st.

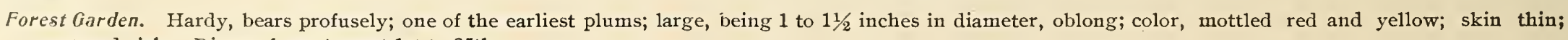
juicy, sweet and rich. Ripens from August 1st to 25th. 


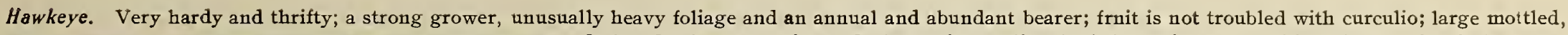

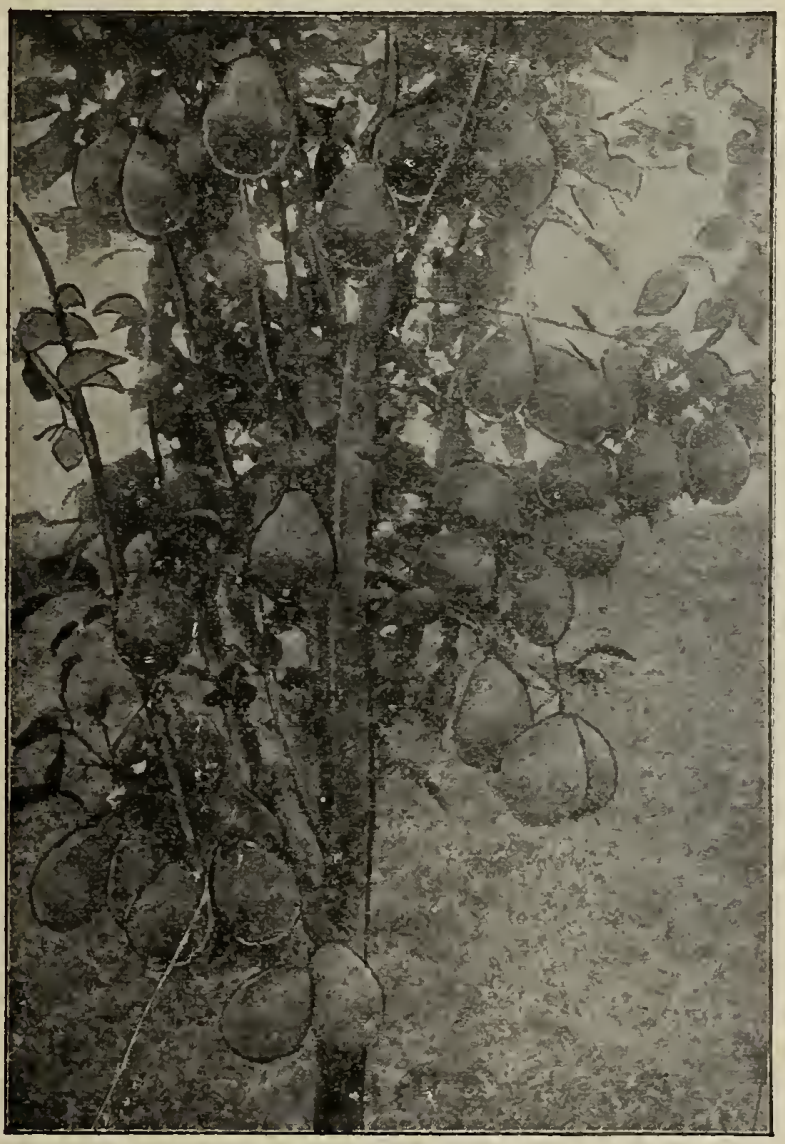

KEIFFER PEAR TREE dark red color; attractive and of superior quality, both for eating and cooking; for canning it is unexcelled. The flesh is very firm, bears shipping well and will be the standard plum for marketing and home use.

Lombard. Medium, violet red, juicy, good, hardy and productive, the leading market variety. Season, August. Not hardy North of Central Iowa.

Miner. Fruit round, oblong; medium size, often small; color dark red with many conspicnous yellow dots and bluish bloom; skin thick; stone medium, cling; quality fair to good. Season late. Is generally productive when planted with other varieties. Not of superior quality, but lateness of season makes it profitable where successful. One of the oldest native varieties known, though not so valuable as its wide reputation might indicate. Originated 1814 in Tennessee by Wm. Dodd, an officer under General Jackson, from seed given him by an Indian chief.

Rollingstone (Americana). Discovered wild about 1860 on Rollingstone Creek (Minnesota) by the veteran plum specialist, O. M. Lord. Size medium to large, (overbears like De Soto and should be thinned to secure large fruit); round, flattened; pinkish purple, mottled and spotted, skin thick; flesh firm, very sweet and excellent in quality; stone semi-cling. Season, medium. The fruit of this variety is not subject to rot and is excellent for shipping. Has been planted and generally highly commended as a vigorous, hardy and productive variety. An early and dependable annual bearer.

Pottawattamie (Chicasaw). Originated in Tennessee and introduced about 1875. One of the best known Chicasaw and deservedly popular where successfulprobably the hardiest of the group. Fruit medium to large, with long, slender stem; color bright red with small yellow dots and white bloom; skin thin, rather inclined to crack: flesh firm, yellow, fair quality; stone cling. Season, August or a little later. For a market plum it is regarded as productive and a fair average seller but quality bettered by other varieties. Not hardy North of Central Iowa.

Surprise. A variety introduced about 1899 by $\mathrm{Mr}$. Martin Penning, of Sleepy Eye, Minn., and is said by many to be the finest in quality of any of the cultivated varieties in the Miner group, also the hardiest of the type. Fruit large to very large; skin medium, thick,

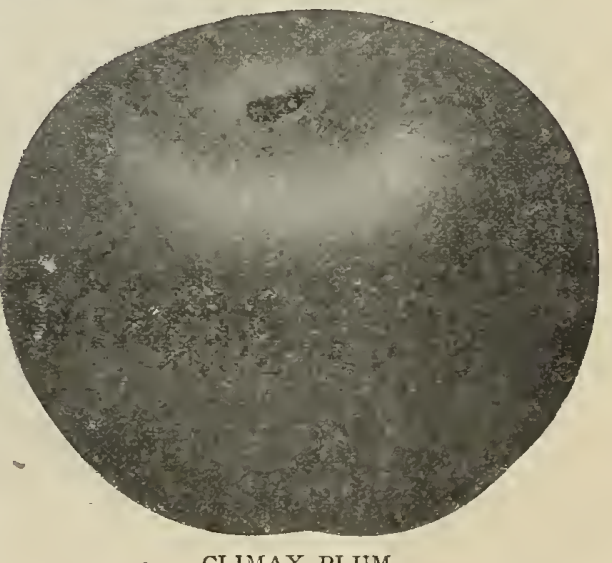

CLIMAX PLUM 


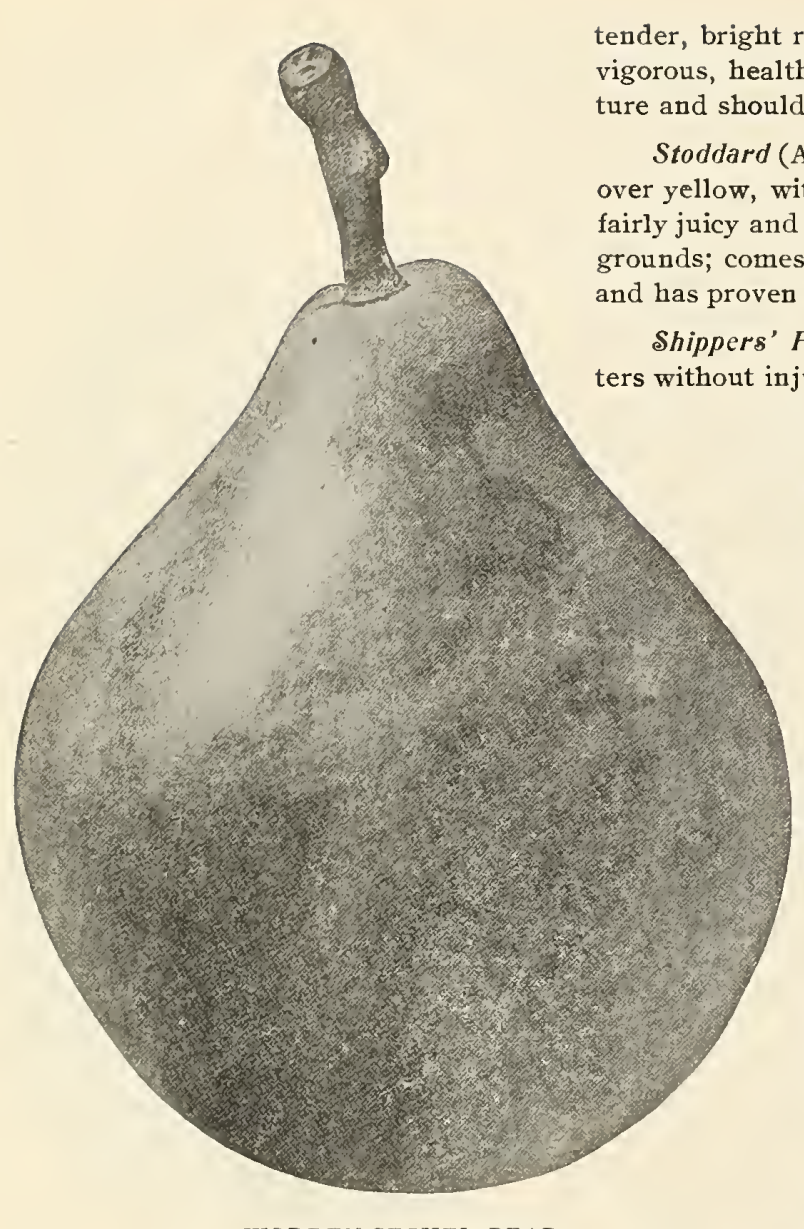

WORDEN-SECKEL PEAR reditesh pale yellow, meaty and of fine flavor; quality extra good. Season medium. Tree an upright ture and should be found in every collection.

Stoddard (Americana). Fruit oblong oval, large, with little or no cavity, short and stout stem; color pinkish red ver yellow, with very small white dots and bluish bloom over all; skin thick and therefore a good shipper; flesh yellow, fairly juicy and of good quality; stone medium, cling; season medium early. Irvins (Iowa) says of it: "Largest on my grounds; comes into bearing very early; extremely productive and very fine quality." Tree is vigorous; upright grower proven hardy.

Shippers' Pride (Domestica). Origin, New York, near Lake Ontario and in that section has stood the coldest winury, bearing large crops annually. Popular in the East and has been fruited successfully as far North as Minnesota. Fruit large to very large, round; color dark purplish blue, very handsome. Season medium late. Excellent for canning and as its name indicates, is a good variety for distant shipping. A prime market sort where hardy, owing to its large, even size, specimens not infrequently measuring two inches in diameter each way. Not hardy North of Central Iowa.

Tatge (Domestica). A variety of the Lombard type and by some thought to be identical with that variety. Originated at Belle Plaine, Iowa, and recently much advertised in the West. Not bardy North of Central Iowa.

Wild Goose (Hortulana). The first native plum to be generally propogated and planted. Was discovered in Tennessee before 1850. Fruit medium, bright, clear red; thin but tough skin; flavor rather sweet. Season medium early. Tree healthy and spreading, blooms in large, snowy banks, and is ornamental. Requires more cross-pollenation than most varieties. Quality not extra, but on account of earliness, productiveness and good shipping quality, has been popular where hardy.

Wyant (Americana). Fruit medium to large, slightly oblong; color purplish red, inclining to orange on shaded side; stone semi-cling; skin thick; flesh rich yellow, sometimes red next to stone; quality good, though variable, being sometimes quite astringent. Tree is a spreading grower and is reported very prolific. A fine appearing plum; some growers consider it superior to Weaver; but that seems still an open question. It is certainly a splendid plum for both home use and market. Originated with Mrs. Mary Wyant, Iowa, about 1871.

Weaver. The tree is very hardy under all circumstances and is wonderfully prolific, and an early bearer; the fruit is large, oblong, of a beautiful color and exquisite quality; flesh firm, freestone, a good keeper. As a canning plum or to be peeled and eaten with sugar and cream, fully equal to the best peach. 
Wolf. Nearly as large as Lombard and a perfect free-stone; superior for cooking and for serving with sugar and cream as peaches are nsed; tree a good grower, very hardy and is becoming popular wherever known. Ripens in August.

Wickson. A new Japanese plnm; a cross between Kelsey and Burbank. The tree grows in vase form, sturdy and upright, yet as gracefully branching as could

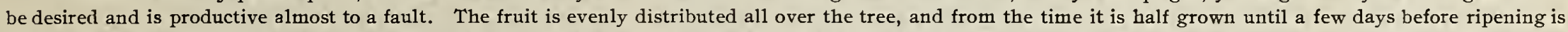

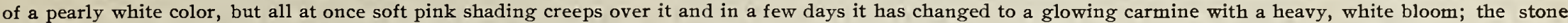

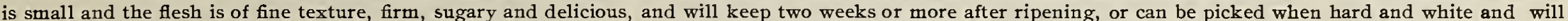
color and ripen almost as well as if left on the tree. Ripens about September 1st. Not hardy North of Central Iowa.

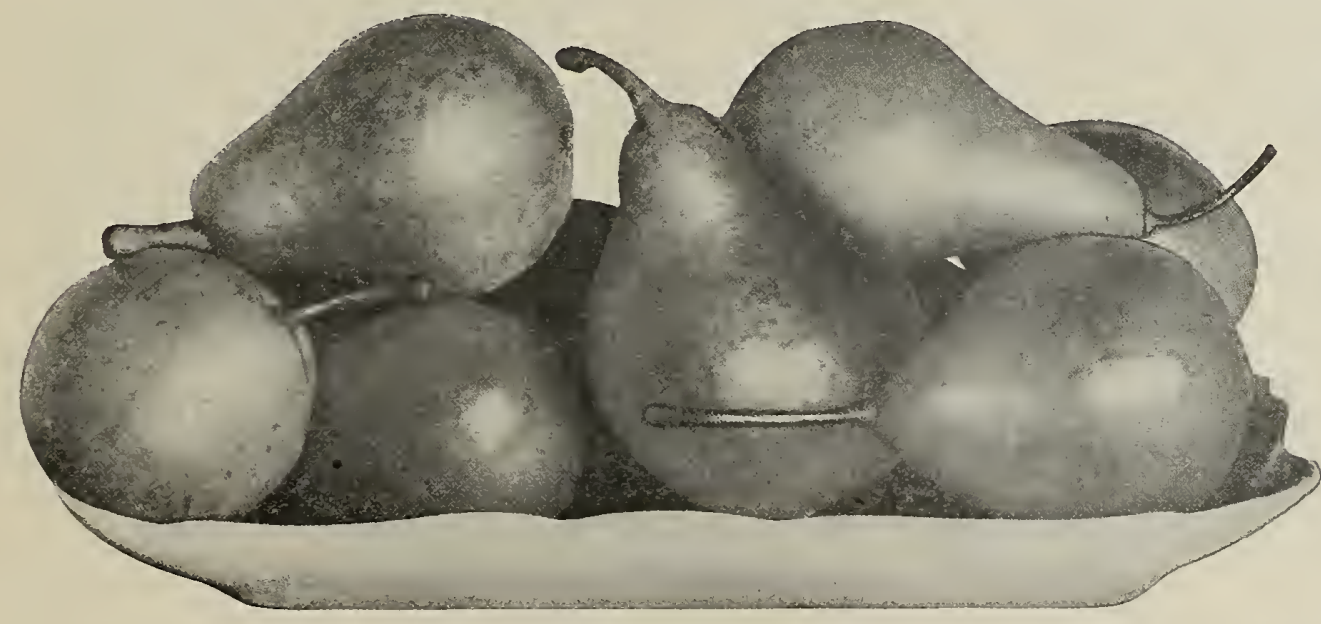

FLEMISH BEAUTY

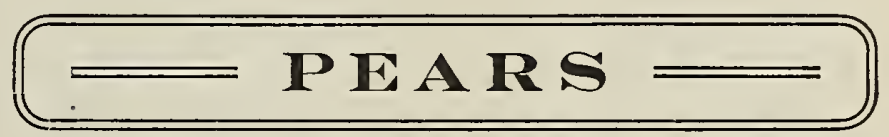

As yet we have no variety of Pear that we recommend for planting North of Central Iowa. The following are the best varieties and the best for planting South of that latitnde:

Bartlett. Large, hutterv, juicy, high flavored, great bearer; very popular. August and September.

Clapp's Favorite. Very large, yellow and dull red, with russet specks, melting, rich. August.

Flemish Beauty. Large, juicy, rich; one of the hardiest and most pupular September and October.

Keiffer's Hybrid. Raised from seed of the Chinese Sand Pear, accidentally crossed with the Bartlett or some other kind grown near it. Tree has large, dark green, glossy leaves and is of itself very ornamental; it is an early and very prolific bearer.

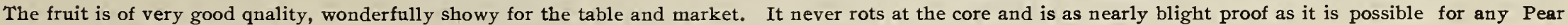
to be. October and November.

Worden-Seckel. A worthy seedling of the famous old Seckel, quite as sweet and luscious, with the same rare flavor and aroma, but superior to the Seckel in size

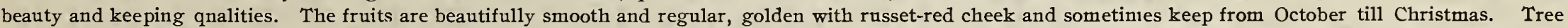

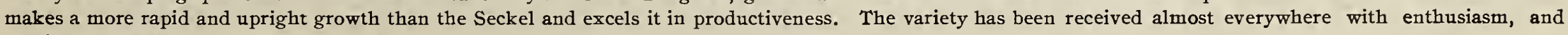
cordially endorsed by competent critics. 


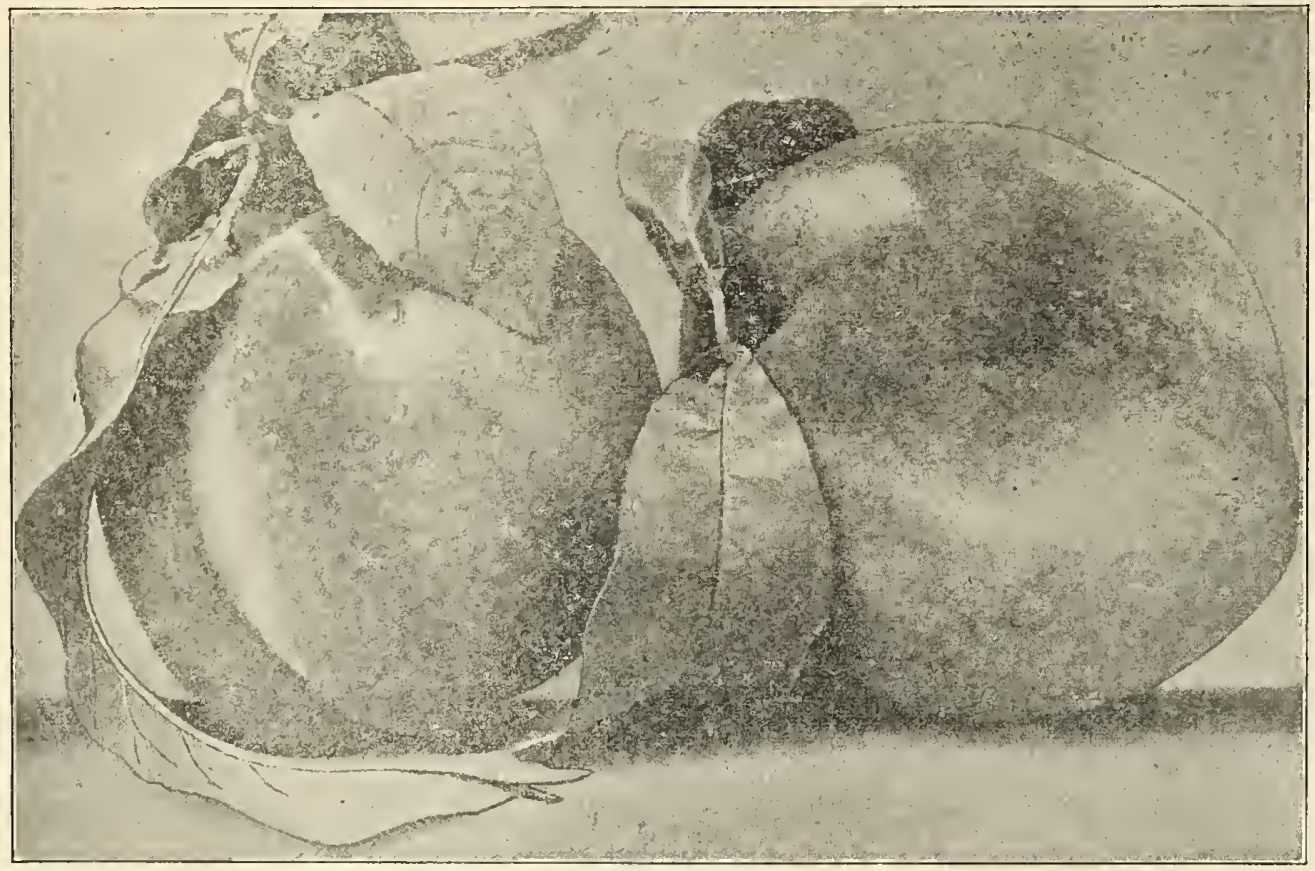

CROSBY PEACH

Iowa. The following are the best varieties for planting in latitudes South:

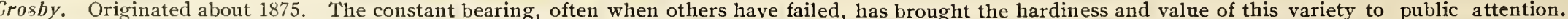

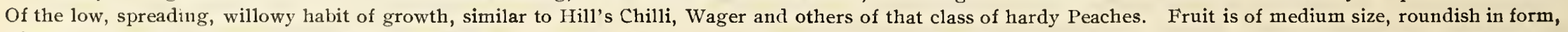

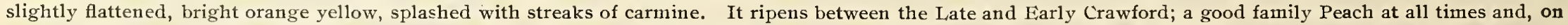

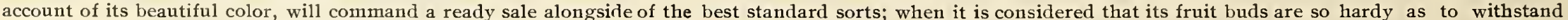

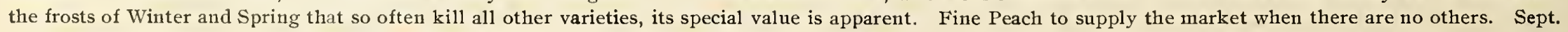

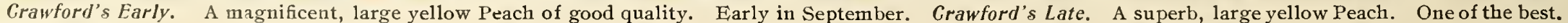
I-ast of September.

\section{PEARS-Winter Varieties}

Bordeaux. A Pear of the largest size, yet with flesh juicy, melting and rich. The thick, tough skin makes it valuable for winter keeping. December to March.

Easter. Large, roundish oval, yellow, with dull red cheek; quality excellent. One of the best Winter Pears. Succeeds best on the quince. December to February.

Lawrence. Medium to large, golden yellow with melting, aromatic flesh. Unsurpassed as an early Winter Pear. The tree is hardy, healthy and productive, bearing large crops annually. November and December.

Mt. Vernon. Of medium size, yellow and russet-red, with yellow flesh of good flavor. Tree bears early. December.

President Drouard. This French variety comes highly commended for its rich flavor and great keeping qualities. The fruit is large, handsome, melting, juicy, highly aromatic; the tree is vigorous, healthy and a prolific bearer. February to March.

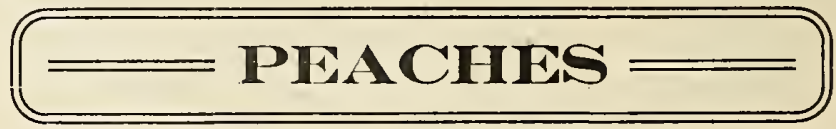

As in the Pear family we have no variety as yet which we can recommend for planting in a latitude North of Central 


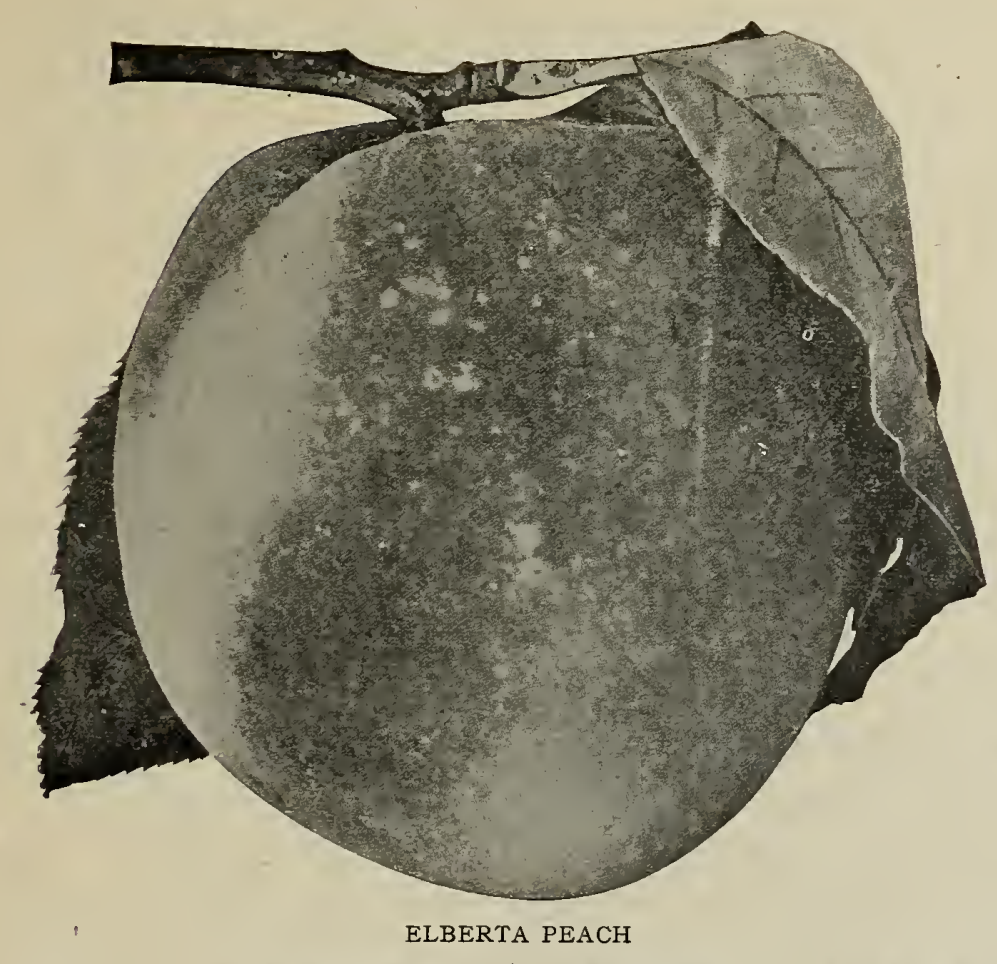

Elberta. Large, yellow, with red cheek; flesh yellow, firm juicy. Exceedingly prolific, sure bearer and hardy. The leading market variety. Follows Early Crawford.

Greensboro. The largest and most beautifully colored of all the early varieties. Double the size of the Alexander, ripening the same time. Flesh white, juicy cool. July.

Kalamazoo. A leading market sort. Large, yellow, fine quality. Extra productive and profitable. First of September.

\section{RUSSIA N A P RICOT}

Introduced from Russia into Nebraska by the Menonites. Quite distinctly hardier than the European varieties; recommended where the other sorts or peach cannot be grown. Productive, early bearer, ripening in July.

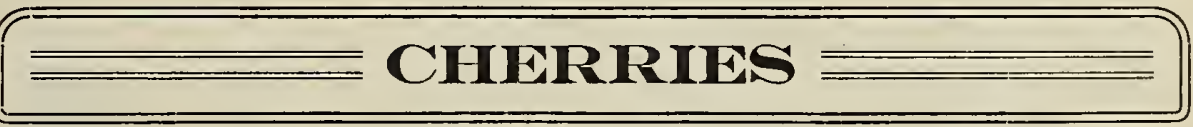

English Morello. Large, dark red, nearly black; tender, juicy, acid, rich. Tree dwarfish and slender. Makes a fine tree on the Mahaleb. If trained on a North wall it may be in use all the month of August. Valuable.

Early Richmond. An early red, acid Cherry, very valuable for cooking early in season. Ripens through June. Tree a free grower, hardy, healthy and very productive. One of the best.

Large Montmorency. Large, red, productive, ten days later than Farly Richmond. Last of June.

Ostheim, or Russian Cherry. A hardy Cherry imported from the nurseries of Dr. Regel, of St. Petersburg, Russia. It has been tested in the severest winters of Minnesota

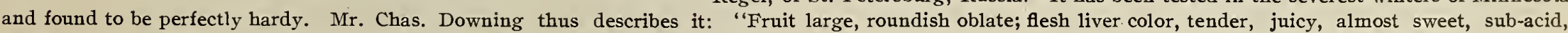
very good. Season, middle of July." Morello class.

Sand Cherry. A fine shrub; extremely hardy, useful where it is difficult to raise a general variety of fruit; very prolific; fruit black, juicy and excellent for sauce and pies.

Black Tartarian. Very large, black, juicy, rich, excellent, productive. Last of June.

Wragg. Originated in Iowa over twenty years ago, where it is standing the severest climate and producing annual crops. Tree very hardy, vigorous and productive; fruit medium to large, dark purple when fully ripe; fine quality; one of the best. Last of July. 


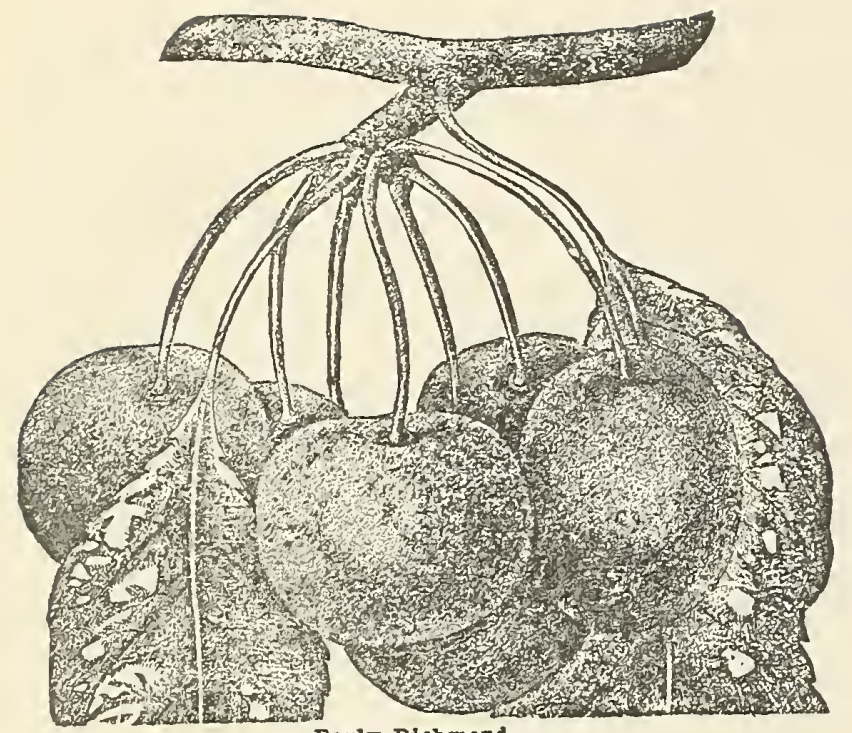

Early Richmond.

Kentish. A variety that is closely akin to the Early Richmond, and may possibly be a seedling of that well known sort. This, however, seems to be considerably hardier and the fruit somewhat smaller. A fine pie cherry.

Homer. A valuable seedling variety originated at Homer, Minnesota. Distinctly of Morello tvpe; fruit medium, larger than Kentish and with smaller pit in proportion; flesh juicy, rich and of excellent quality; flavor very similar to Early Richmond; color dark red. Has attracted nuch attention among Minnesota growers on account of its apparent hardiness.

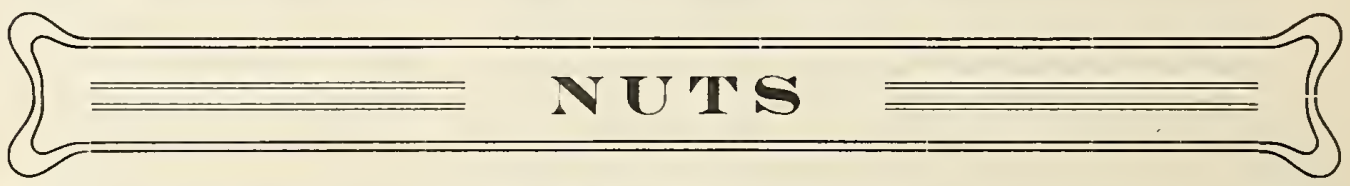

Almost every farm contains land that should be planted to nut trees adapted to the soil. Probably no br inch of tree cultivation pays larger profits or is as well assured of a profitable market for all products, the nuts in many cases paying better than farm crops or fruits, while most kinds are making a growth of valuable timber that will of itself pay a large per cent. on the investment.

Black Walnut. (J. niga). A native species of great size and majestic habit. Bark very dark and furrowed; foliage very beautiful, each leaf being composed of from thirteen to seventeen leaflets. Nuts round and valuable for fruit or timber.

Butternut, or White Walnut. The nuts are large, long, oily and nutritious. The lofty, spreading tree is one of our finest natives, valued for its tropical appearance and beautiful wood, as well as for timber.

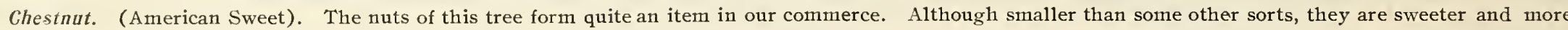

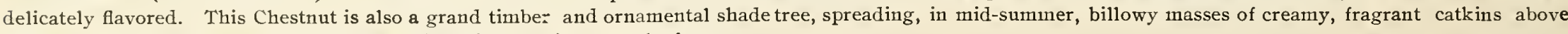
its large, deep green leaves, making a most beautiful specimen on the lawn.

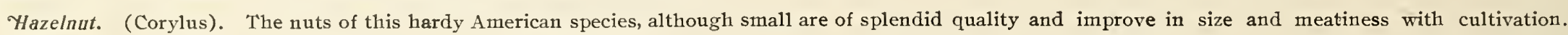
The bushes are of fine form and foliage and have high ornamental value.

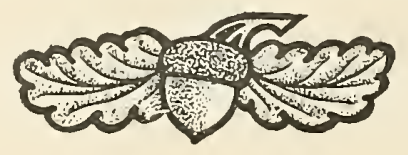



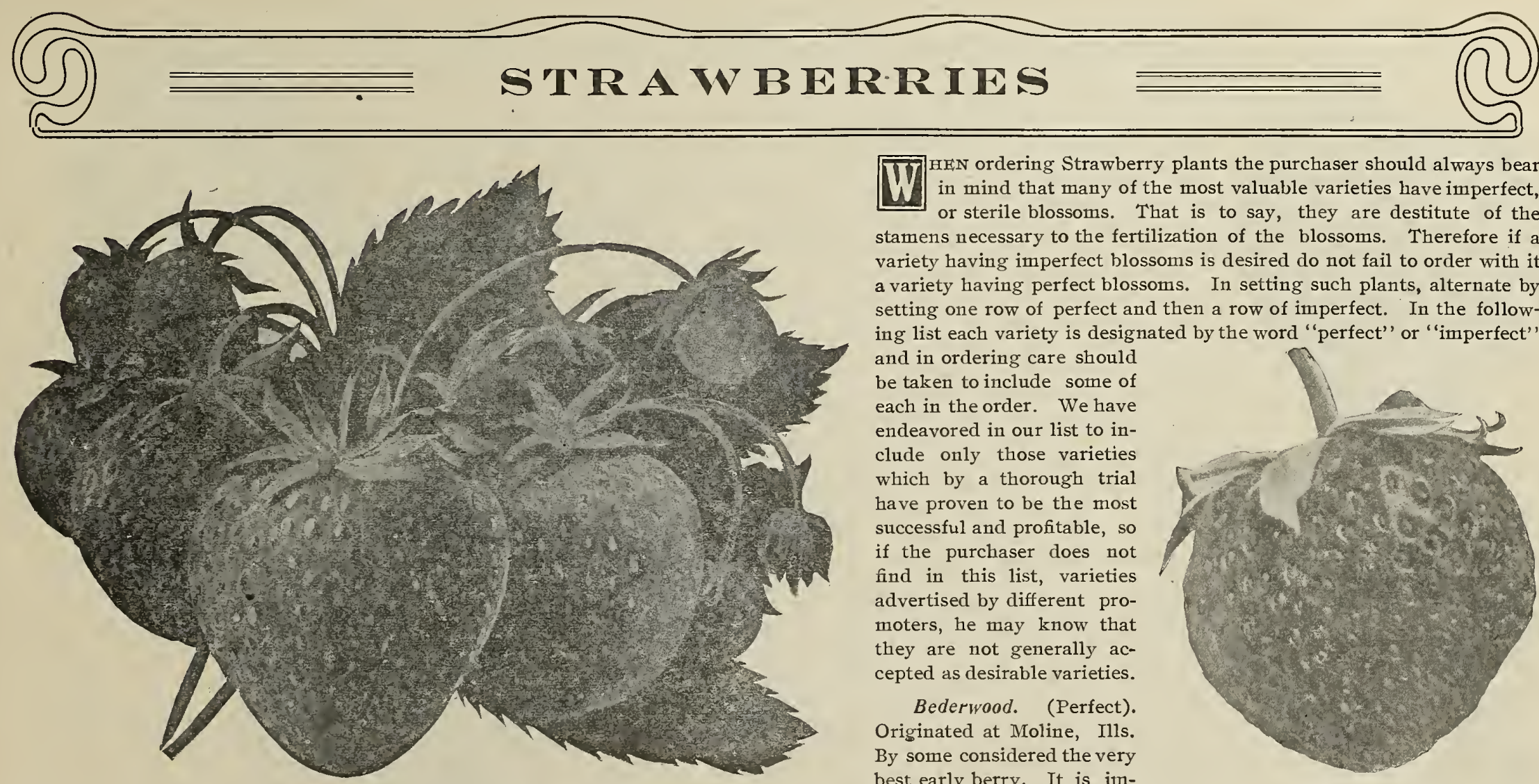

TIT HEN ordering Strawberry plants the purchaser should always bear W in mind that many of the most valuable varieties have imperfect, or sterile blossoms. That is to say, they are destitute of the stamens necessary to the fertilization of the blossoms. Therefore if a variety having imperfect blossoms is desired do not fail to order with it a variety having perfect blossoms. In setting such plants, alternate by setting one row of perfect and then a row of imperfect. In the following list each variety is designated by the word "perfect" or "imperfect" and in ordering care should be taken to include some of each in the order. We have endeavored in our list to include only those varieties which by a thorough trial have proven to be the most successful and profitable, so if the purchaser does not find in this list, varieties advertised by different promoters, he may know that they are not generally accepted as desirable varieties.

Bederwood. (Perfect). Originated at Moline, Ills. By some considered the very best early berry. It is imSENATOR DUNLAP (Perfect)

mensely productive. The

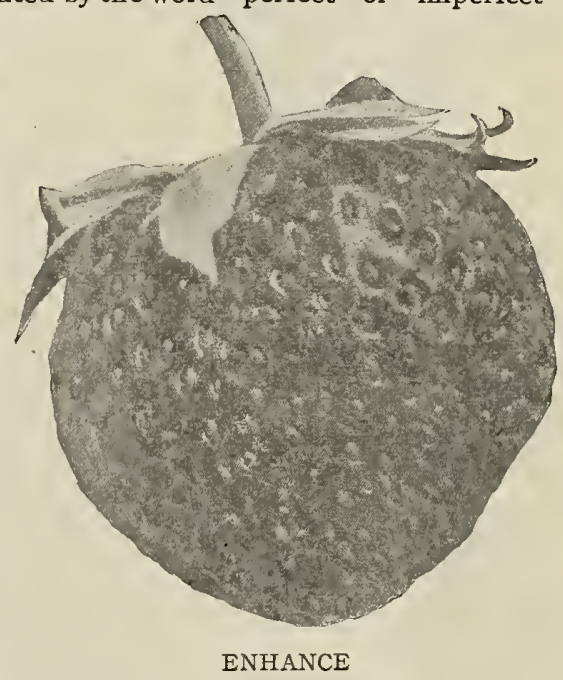
plant is a good, healthy grower, and sends out a large number of runners. Fruit large, conical, bright red, and of excellent quality. An excellent fertilizer for the Warfield. One of the most popular varieties for the Northwest. 


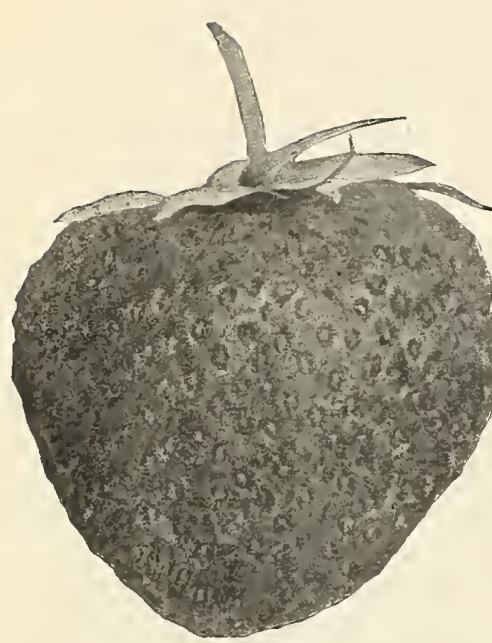

CLYDE

Brandywine. (Perfect). A valuable late variety that has many friends. Berries are large, roundish-conical, bright glossy crimson, firm and of good flavor. For best results it should be grown on strong, rich soil, as is the case with all large berries. In some sections it is classed among the mid-season varieties.

Clyde. (Perfect). A strong growing, perfect blooming, healthy plant, with light green foliage. Everywhere tested it proves to be exceedingly productive of large, globular, perfectly formed, light scarlet berries of fine quality. Always inclined to overbear; some plants have more fruit stalks than leaf stalks. A light application of nitrate of soda in early Spring, before fruiting, or a top dressing of stable manure in Winter, will stimulate greater foliage growth, and so help the fruiting of this remarkable variety. There are few strawberries that succeed as well over as wide a range of country as the Clyde; no family collection can be complete without it.

Crescent. (Imperfect). Very early, of medium size, bright scarlet. An old, wellknown variety.

Enhance. (Perfect). Medium to late, long season and good pollenizer. Berries somiewhat irregular in shape, medium to large and firm. A rank, vigorous grower, with very heavy foliage.

Haverland. (Imperfect). Originated in 1882 by H. B. Haverland, of Hamilton, Ohio, from seed of the Crescent fertiliz-

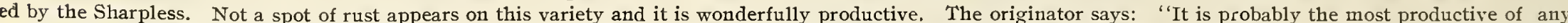

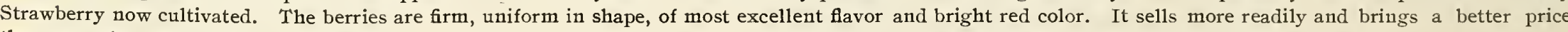
than any other Strawberry. The plants are very large, healthy, vigorous and ripen their fruit evenly and early, holding on through the season."

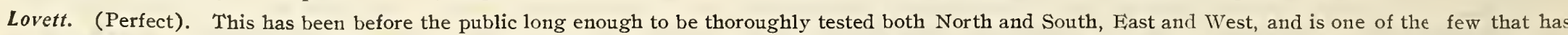
been universally adopted. It is not only a first-class all around berry, but one of the best to do duty as a pollenizer. The plant is a strong, healthy grower, clean foliage, fruit medium in size, high, rich color, firm and productive. It is commonly paired with the Warfield and others of its season as a pollenizer. It is very reliable and will succeed in almost all soils and conditions.

Senator Dunlap. (Perfect.) A well tested, wonderfully productive variety, one of the safe sorts to plant everywhere and sure to take a high place among the prominent standard sorts. Plant resembles the Warfield, rampant runner, should be restricted in its production of plants, fully equal to Crescent and Warfield in its ability to susceed under all circumstances. Fruit good size, regular form, beautiful bright red, glossy, firm, splendid keeper and shipper, excellent quality; one of the best for canning; ripens early and continues a long time. It promises to stand at the head in its ability to ripen a good crop under almost any condition of drouth or neglect.

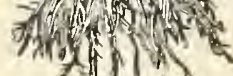

Ant

Good Plant8.
Splendid. (Perfect). From Northern Illinois; the best berry for home market and table use yet produced; better and larger than Crescent and ripens one week earlier; berries even in size, all ripening about the same time; very prolific; flavor excellent; self fertilizer. 
Warfield. (Imperfect). A seedling discovered by B. C. Warfield, of Illinois, in 1883 . It fruited in 1884, and a bed containing five square feet yielded a quart

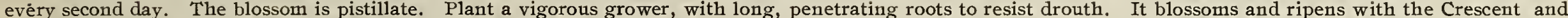

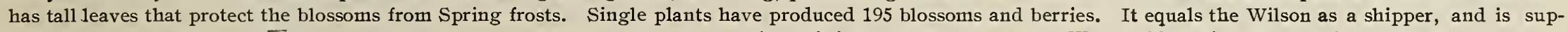

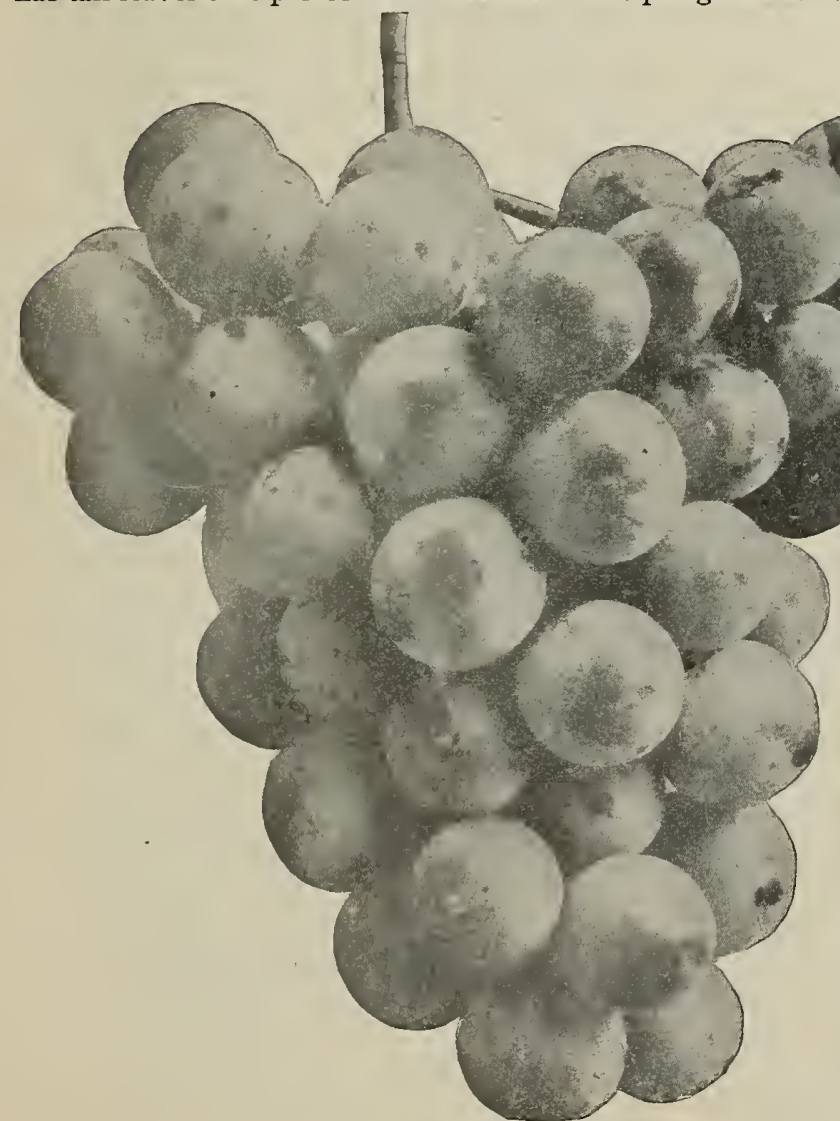

MOORE'S EARLY erior to it in every other respect. We consider this as the coming market berry.

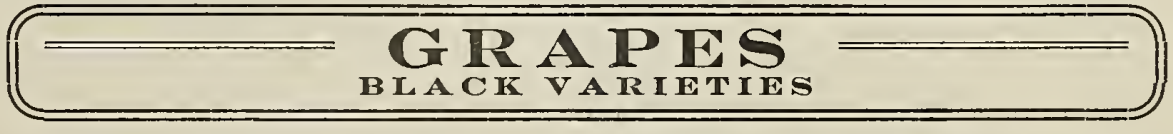

Campbell's Early. This superb new berry is fulfilling the promises made for it remarkably well. It forms large and handsome clusters thickly set with large round berries, covered with a light, purple bloom; these are firm-fleshed enough to keep and ship admirably, but the tender pulp parts readily from the few, small seeds, a quality that is now greatly appreciated; the flavor is rich, sweet and delightful. The clusters ripen very early and hold their berries well, keeping in fine condition for a month or more. The vine is vigorous and bears abundantly. Should be widely planted.

Concord. The fine, old market leader, with handsome clusters of large luscious Grapes. Entirely hardy, productive and reliable; succeeds well over a great extent of country. One of the best known grapes grown. September.

Early Ohio. New black. Originated at Euclid, Ohio, by Mr. R. A. Hunt. Bunch large, shouldered, berry medium. The earliest grape known, ripening fully ten days earlier than Moore's Early. Unlike most early varieties the berries never shell, a quality highly appreciated by those who grow Grapes for market. Vine a strong grower and very productive, perfectly hardy, having stood uninjured in very severe weather when Concord buds in the same vineyard were ruined. In growth, foliage and general habits the vines resemble the Concord.

Janesville. A very desirable Grape on account of hardiness, quality and early ripening. Color black; bunch solid; very good flavor; when fully ripe, quite sweet. Ripens from the 15 th to the 20th "of August.

Moore's Early. Black, with heavy bloom; bunch medium size; berry very large, better than Concord in quality and with more pulp; vine a moderate grower, very healthy and hardy, moderately productive; a valuable market variety on account of its earliness. 'Ripens some twenty days earlier than the Concord.

Worden. Black, bunch very large and compact; berry very large; fully as productive, hardy 


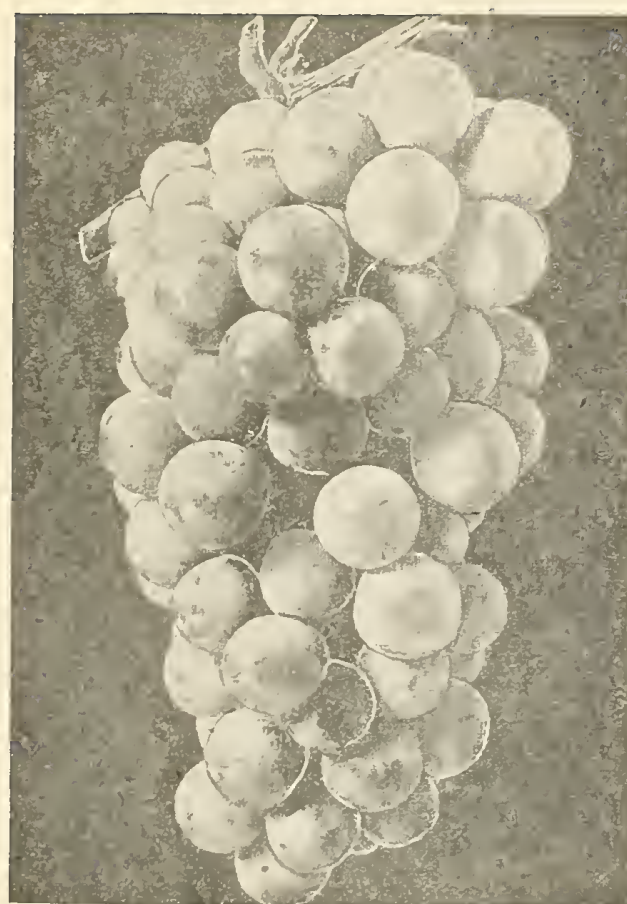

DOWNING GOOSEBERRY

and as strong a grower as the Concord; quality much better and ripens a few days earlier. Will not keep as well, but if handled when first ripe is as good a shipper as the Concord. Is steadily increasing in popular favor.

\section{G R A P E S-R E D VA R I T TES}

Agawam. (Roger No. 15). Vigorous grower; bunch good size, shouldered rather loose; berries large and round; color darker than Deleware; skin thin with juicy pulp; very sweet, with rich, aromatic flavor. Season, ten days earlier than Concord.

Deleware. Rather slow grower. Bunch medium, compact; berries medium, skin thin, dark red color; flesh tender and juicy, exceedingly sweet. Ripens in September, and, as a rule, commands in market from one-third to one-half higher price than the ordinary varieties.

$=$ WH I T F G R A P F S $=$ Grape in America. Bunches very large, often weighing one pound; berry large, immensely productive, a rank grower; when in its best condition, excellent; a little later than Concord; has a flavor peculiar to itself that is esteemed by many.

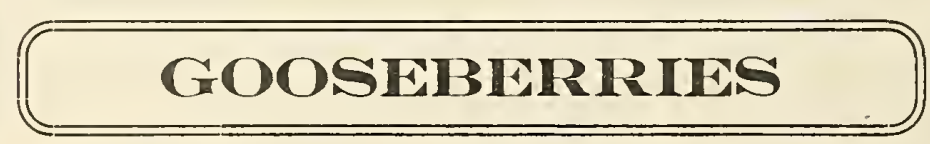

A deservedly popular fruit, making as it does, the richest of canned fruits for winter, and also, as is the case with the improved varieties, being excellent for eating out of the hand. Set in rows six feet apart, four feet apart in row.

Columbus. This is one of the most valuable introductions of recent years. The fruit is of the largest size, pale yellow in color and of the finest quality and flavor. Bush vigorous, productive and free from mildew. Combines size and beauty of the English varieties with the requisite hardiness of the native sorts.

Downing. Fruit larger than Houghton; roundish, light green, with distinct veins; skin smooth; flesh rather soft, juicy and very good; vigorous and productive.

Houghton. An enormously productive and always reliable, old variety of vigorous growth, slender and spreading, not subject to mildew. Fruit of medium size, smooth, pale red, tender and of good quality. About equal in hardiness to American.

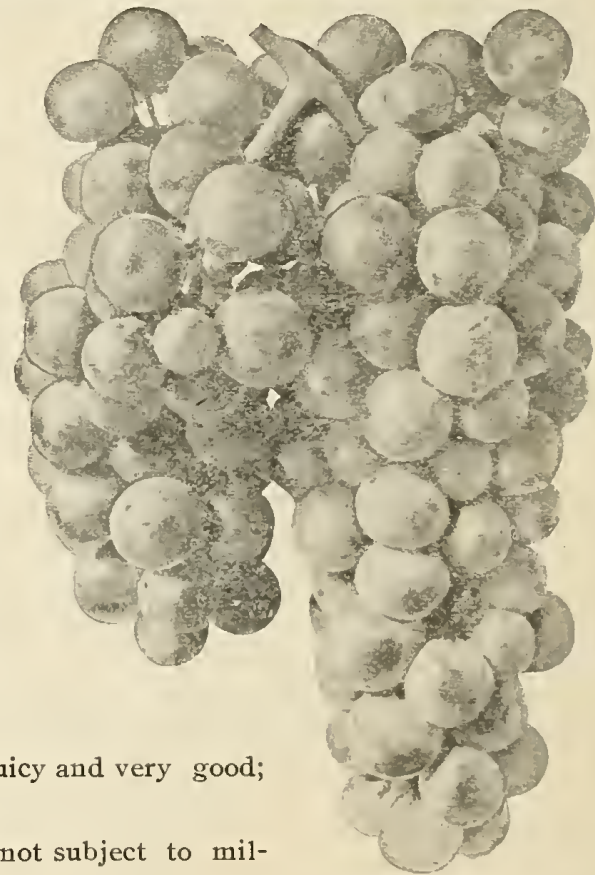

CAMPBELL'S EARLY 


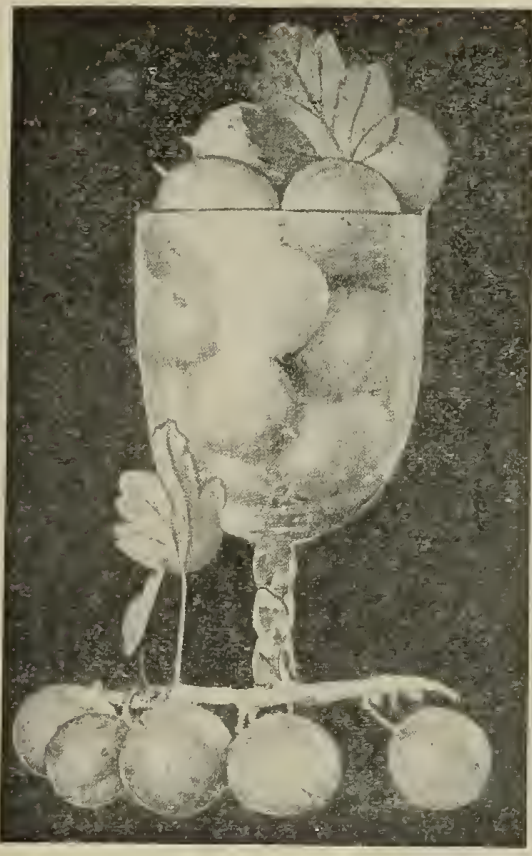

DOWNING GOOSEBERRY

Pearl. A new variety of great merit; twice as large as the Downing and fully equal to it in quality. Probably the most productive Gooseberry grown. In quality the very best. Nearly sweet and of excellent flavor. Free from mildew. At the Michigan State Experimental Station, on a ten point scale, it is noted for productiveness 10 and for quality 9; none surpassing it.

Red Jacket. (Josselyn). A new red berry, as large as the largest; smooth, very prolific and hardy; quality and foliage the best. For many years it has been tested by the side of the best American and English sorts, and it is free from mildew, either in leaf or fruit. Promises to be the variety we have sn long been waiting for. Equal to the best English kinds and capable of producing large crops wherever Gooseberries can be grown.

Transparent. New, very hardy, bushes of strong, vigorous growth, maturing and fruiting early; bears abundantly; berries almost as large as the Downing; pale green.

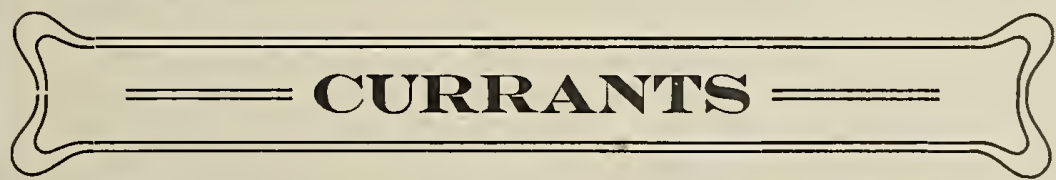

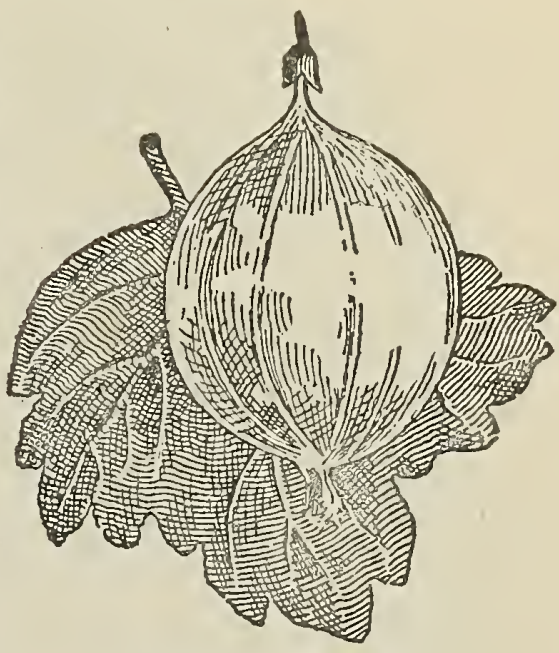

PEARL GOOSEBERRY

Gherry. Bush vigorous, stocky and compact; cluster rather short, with stout stem; fruit averages large; color bright red; very thin; juicy and fine flavor; one of the most productive of large currants.

Long Bunch Holland. One of the best late varieties; bush very vigorous and hardy; clusters very long; berry medium to large, bright red and of good quality.

London Market. For many years this variety has been fruiting in Michigan, where it is now fruited extensively and

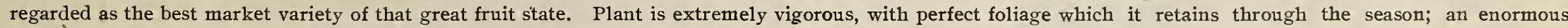
croper. Ripens with Victoria, is larger in both bunch and berry, a better bearer. For any use, home, garden or market, one of the best.

Lee's Prolific. The best black Currant for all purposes. Early, large and productive. Quality splendid. It is as sweet as a huckleberry and much like it.

North Star. The points of excellence are its hardiness, vigorous growth of wood, early fruiting and great productiveness. The average growth for 1889 (an ex-

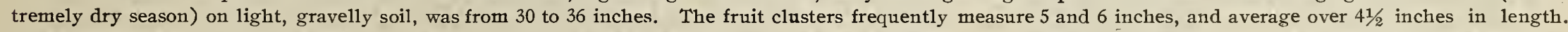

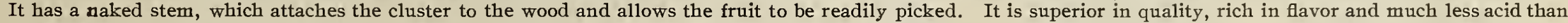
old sorts.

Perfection. (See illustration, page 46). A new variety from New York. It has been awarded many valuable prizes and medals. Certainly approved by the 


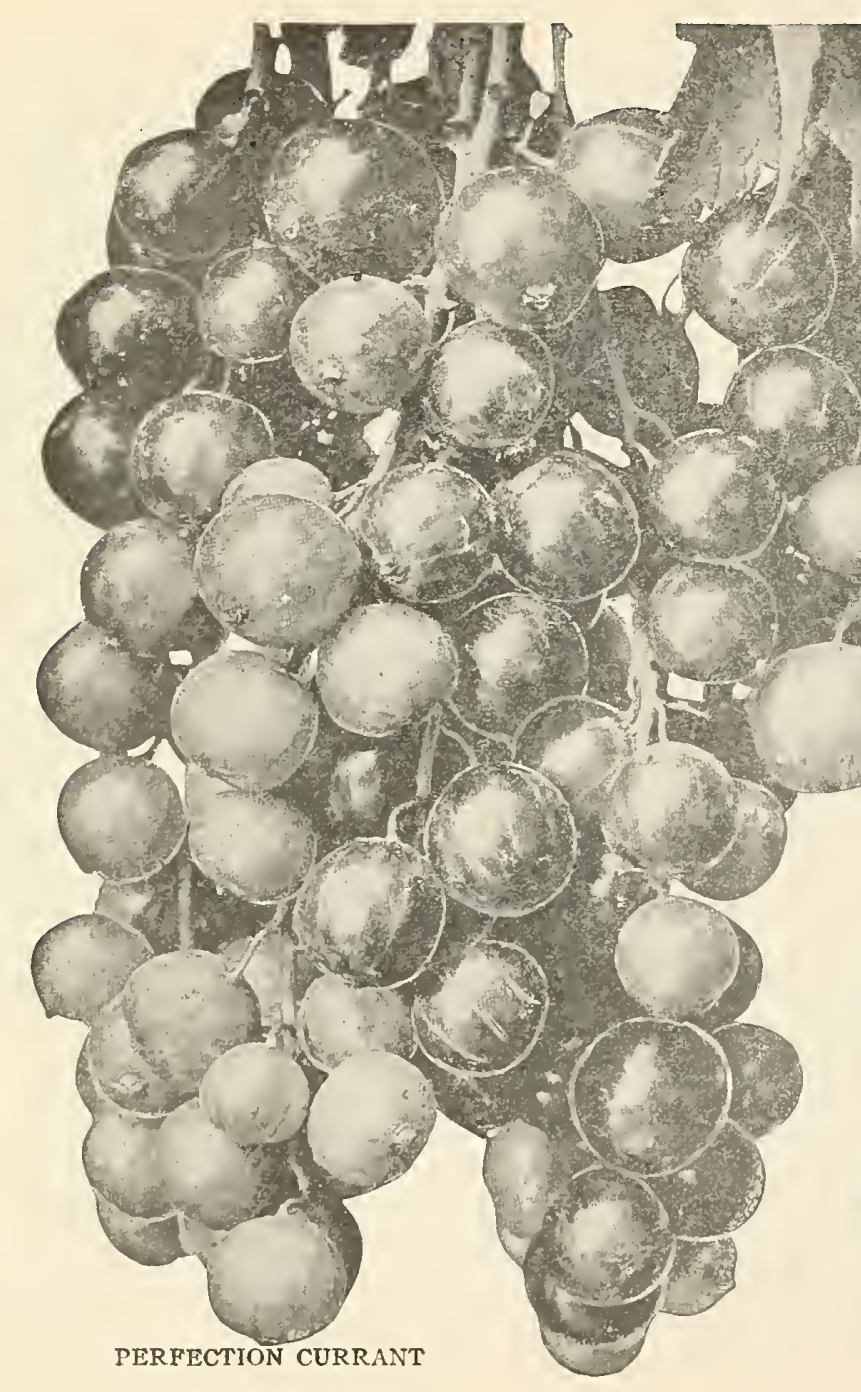

very highest authorities and should be tested everywhere, as there is big money in growing large currants. The Perfection was awarded the Barry Medal, the fifty dollar gold medal of the Western New York Horticultural Society, July 1901, (after three years' trial), the first fruit to receive this grand prize. It also received the highest award given any new fruit at the Pan-American Exposition. The color is a beautiful bright red; size as large or larger than the Fay, the clusters averaging longer. The size of the fruit is well maintained to the end of the bunch. The Perfection has a long stem from point of attachment to the bush to the first berry, making it easy to pick without crushing any of the berries. The Perfection is a great bearer, resembling its parent, the White Grape, in this respeet; superior to the Fay or any other large sort with which we are acquainted. The season of ripening is about the same as that of the Cherry or Fay. Quality rich, mild, sub-acid, plenty of pulp with few seeds. Less acid and of hetter quality than any other large Currant in cultivation. The White Grape has always been considered one of the best varieties for table use, and the effect of this strain is plainly seen in the very fine quality of Perfection. In habit and growth it is intermediate between its parent Fay and White Grape, with remarkably large, healthy foliage.

Red Dutch. Of fine quality; the sweetest of all. The berries are small but very abundant. The best for jelly, wine, etc.

White Grape. Very large, yellowish white; sweet or very mild acid; excellent quality; valuable for table; finest of white sorts; very distinct from White Dutch, having a low, spreading habit and dark green foliage. Very productive.

Well-Known Varieties. Improved Cherry, Victoria, Naples (black). New Varieties. Crandall (black), Fays, White Gondoin, Long Bunch Holland.

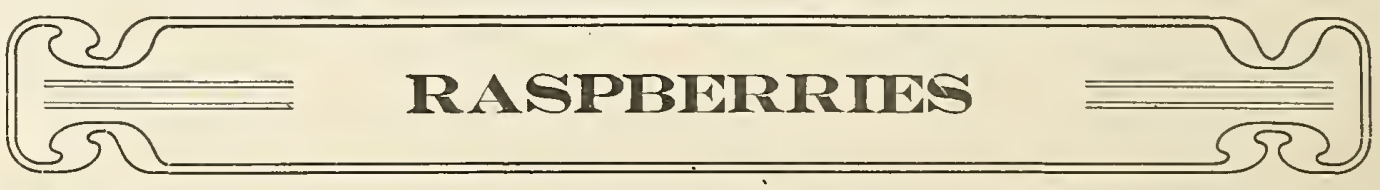
1 HIS popular berry, coming just after Strawberries, is welcome to fill out the berry season before Land should be thoroughly prepared and well enriched (ground bone is one of the best fertilizers). Keep well cultivated and free from weeds and suckers. As soon as they are done bearing, cut 


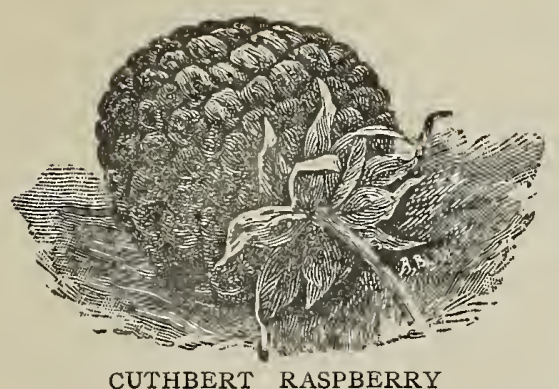

CUTHBERT RASPBERRY out old wood to give more vigor to young canes. Plant in rows five feet apart, three feet apart in rows.

\section{R E D V A I E T I S}

Brandywine. (Susqueco). A large bright red Raspberry that has proven very valuable for market on account of its fine shipping qualities. Ripens up evenly and is very firm. The canes are vigorous and healthy. Has long been popular in Fastern States, where it originated.

Cuthbert, or Queen of the Market. A remarkably strong, hardy variety; stands the Northern Winters and Southern Summers equal to any. Berries very large, conical, rich crimson, very handsome, and so firm that they can be shipped hundreds of miles by rail in good condition. Flavor is sweet, rich and luscious. The leading market variety for main crop.

Clark. A well known variety that has long been in cultivation and is one of the very best red Raspberries for home use. A strong, vigorous grower and may be depended upon for annual crops on any good soil. The fruit is medium to large, conical; color bright crimson; highly flavored, juicy, sweet and of excellent flavor.

King. Several of our leading fruit growers consider this one of the best of the early red Raspberries. Berries large and attractive, bright red in color and of good flavor. Ripens with the earliest and is firm enough to ship well. The canes are healthy and productive.

Miller. Bright red, averaging large as picked, round in shape and of fine quality; one of the firmest and best shippers for early market and is grown extensively in many sections. The canes are of vigorous, upright growth and immensely productive where given the proper cultivation.

Turner. A vigorous grower, early, fruit of excellent quality, good bearer and very hardy.

The Loudon. This Raspberry is without doubt the largest, most productive and best of the red varieties. No new berry has been so universally approved by all who have used it. We have not heard a word from any one except in praise of its good qualities. It has proven perfectly hardy, a wonderful bearer, a good, firm market berry and of excellent flavor.

\section{P URPLE VARIETIES}

Golumbian. Fruit resembles Shaffers, very large, purplish color, rather soft; rich, sprightly flavor, unrivalled for canning, making jam, jelly, etc. Bush wonderful for vigor of growth and productiv-

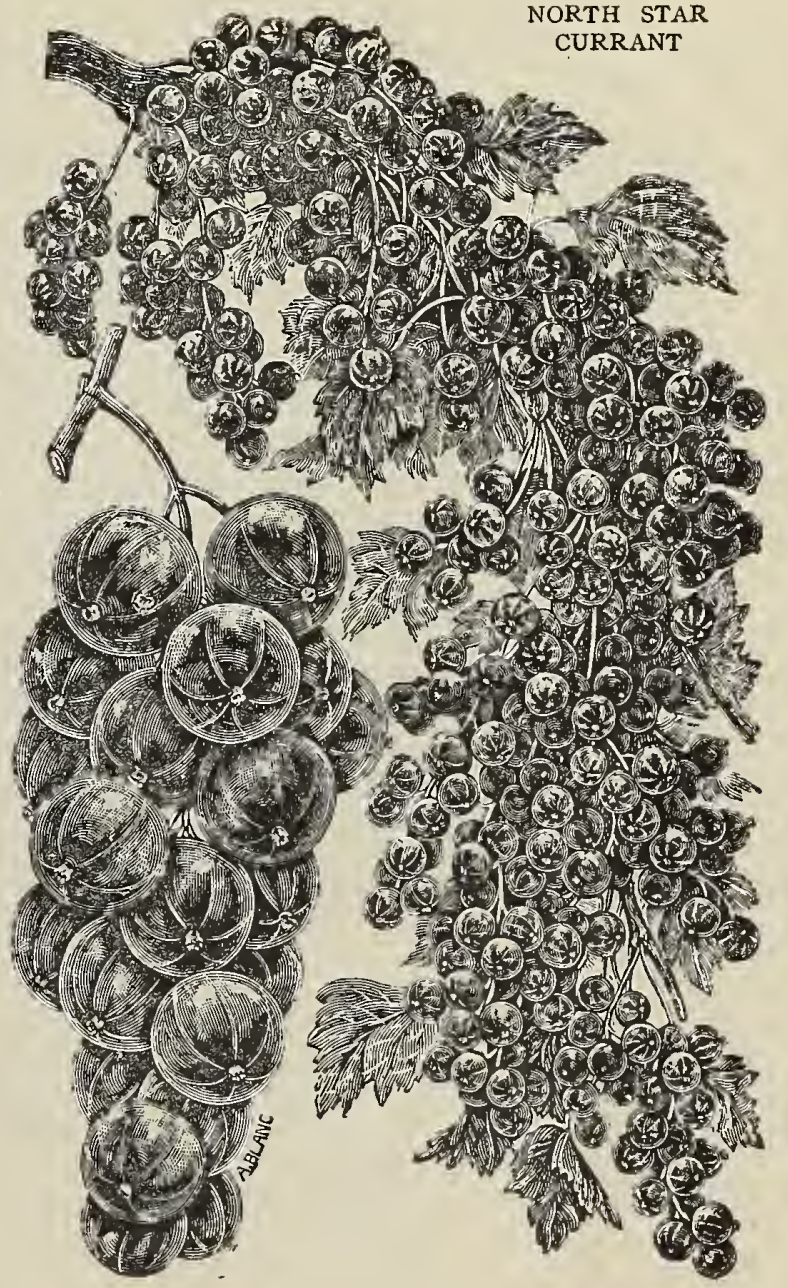




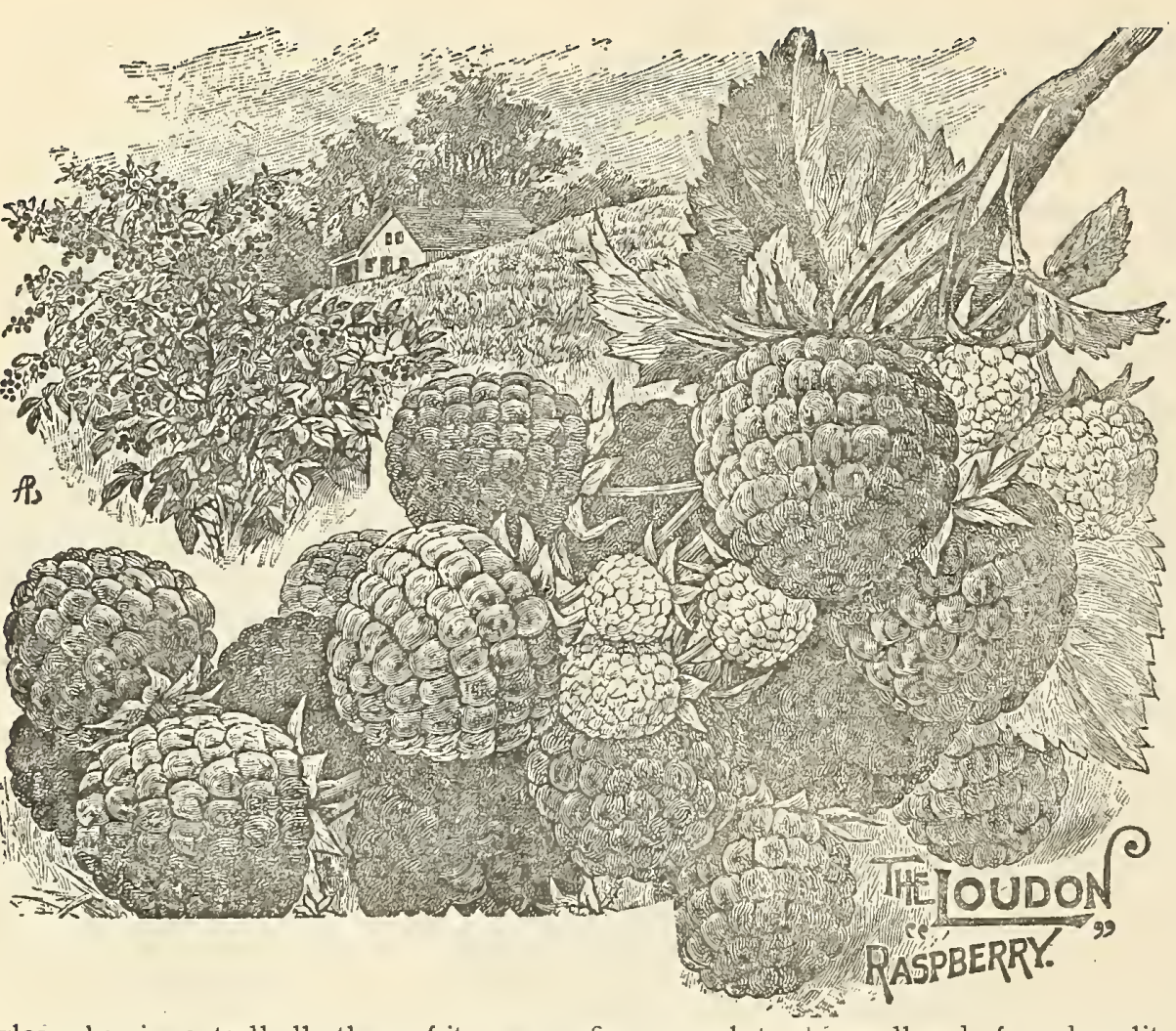

ness, attaining a very large size and producing immense crops.

Haymaker. This is another seedling of the tall, strong growing Columbian type and highly recommended by many growers. The berries are similar in color, size and texture, but are slightly more acid and are producing even heavier crops than either Columbian or Shaffer. A valuable variety for market gardening.

Shaffer's Crlossal. One of the best purple varieties for family use unequalled for canning; flavor rich and sprightly. The bush is a strong grower and entirelv hardy; does not "sucker" or sprout from the roots like red varieties, but propagates from the "tips" like black caps. This variety is nonderfully prolific; has yielded one hundred bushels per acre for several years in succession.

\section{YEI, L OW VA R I ETIES}

Carolina. A more recent introduction of the yellow Raspberry. Verv similar to Golden Queen although some growers regard it of better qualitv. The plant is a vigorous grower, bat not generally so strong as the Golden Queen.

Golden Queen. A beautiful, large, golden yellow berry, seedling of the Cuthbert and surpassing that variety in size, beauty, quality and adaptibility. Canes hardy, of strongest growth, productive. Should be in every home garden, its beauty and high quality placing it at the head for table use.

\section{BIA A K C A PS}

Cumberland. A new black variety which has been considerably advertised as the business black cap. Very large and similar to Gregg in quality and firmness. In productiveness it is unexcelled. Its large, glossy berries outsell all others of its season; firm enough to ship well and of good quality. One of the best mid-summer market berries.

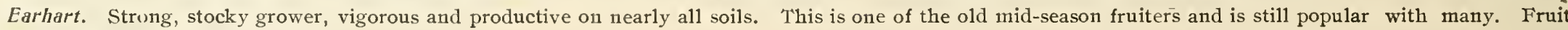
is large, jet black and of good quality.

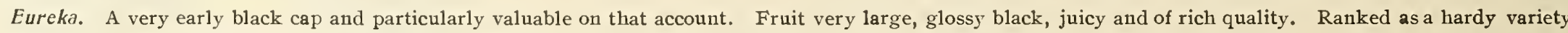
in cane and in some localities ranks first in productiveness. 


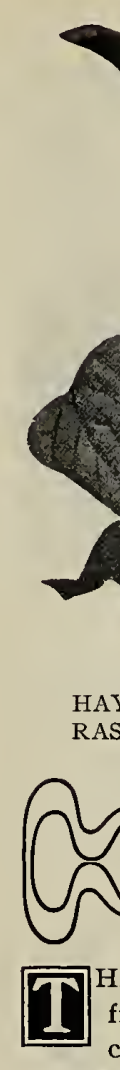

Gregg. A hardy black cap; one of the best market Raspberries grown. Very productive the yield under good cultivation is enormous. Berries very large, covered with a whitish bloom; quality good, firm in shipping.

Kansas. Strong, vigorous grower, standing extremes of drouth and cold, and bearing immense crops. Farly, ripening just after Palmer. Berries size of Gregg and of better color; jet black and almost free from bloom; firm, of best quality; presents a handsome appearance and commands highest price in market.

Nemaha. Originated by Hon. Robt. Furnas, of Nebraska. Has been well tested on our experimental grounds, and we recoumend it. For hardiness, strength and growth of cane, productiveness, size and quality of fruit, it is unsurpassed. The berry is la:ge, black and firm. It is doubtful if a better berry can be found.

Palmer. The first to ripen; fruit of good size and quality; canes wonderfully productive, vigorous and hardy; ripens its crops in short time.

Winona. A large, desirable, new variety; fine grower and hardy; fruit buds close together; heavy bearer.

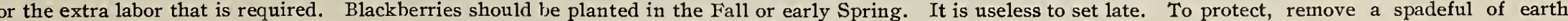

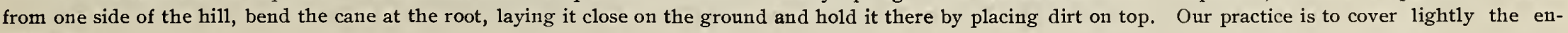
tire cane.

Agawam. Fruit of fair size, jet black, sweet, tender and melting to the very core. For home use it has no superior, being sweet throughout as soon as black; it is extremely hardy and healthy, and very productive. 
IIncient Briton. A valuable variety that is becoming very popular in many sections. Sells well in market and is very profitable; berries large and sweet. Does better on sandy land than on heavy soil. Requires IVinter protection but is well worth the little labor this costs.

Erie. One of the best hardy varieties, as vigorous as Kittatinny; very productive; foliage clean and healthy; free from rust; about the size of Lawton, round in form, giving the appearance of being larger than it really is; good quality; ripens between the Early Harvest and Wilson Junior.

Early Harvest. One of the most valuable where it succeeds; is not entirely hardy in the North and needs Winter protection. Its earliness, being one of the first to ripen, combined with good shipping qualities, make it very profitable. Compact, dlwarf grower, enormous bearer. Fruit medinm size, black, of excellent quality.

Stone's Hardy. An upright and vigorous grower; stocky,

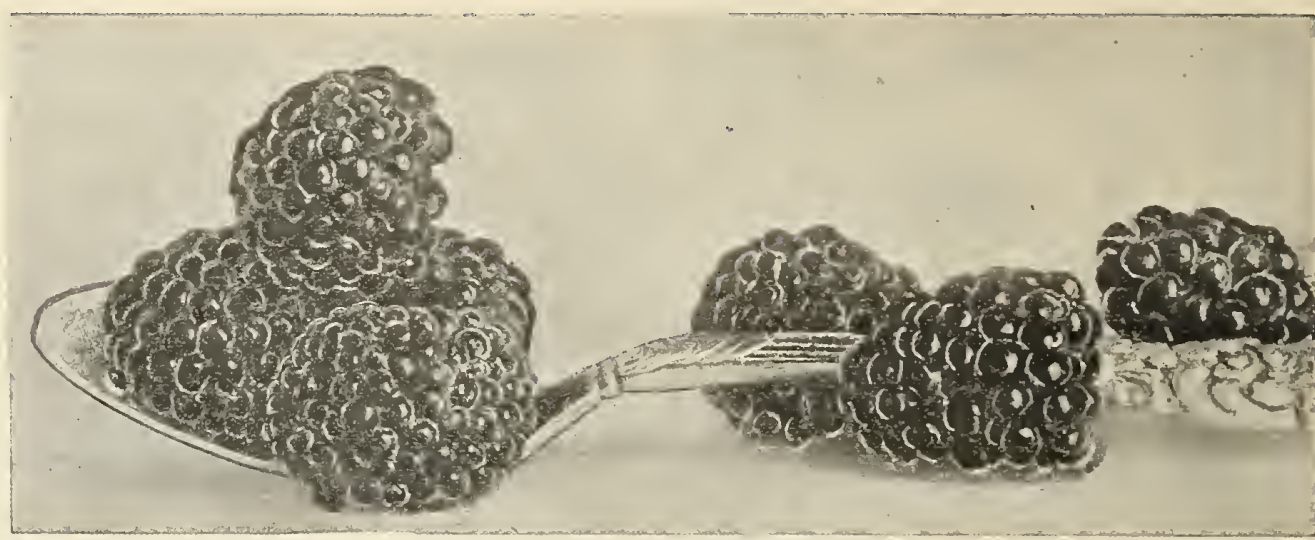

CUMBERLAND RASPBERRIES AS COMPARED WITH SNYDER BLACKBERRIES

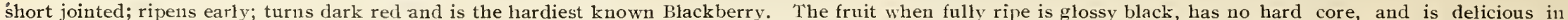

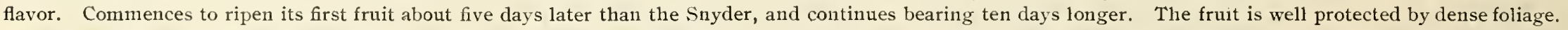

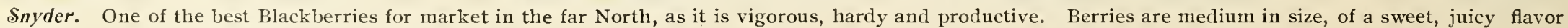
and when fully ripe, without the hard core of other sorts.

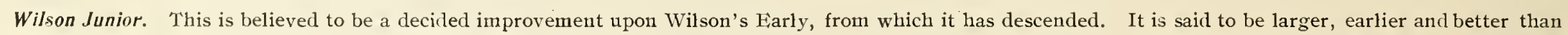
the parent variety. Very sweet and of excellent quality.

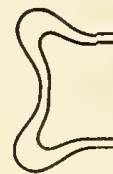

\section{MIS C ELIA N EOUS}

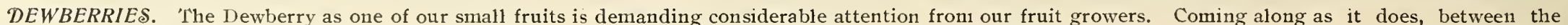
Raspberries and Blackberries, it is of great value.

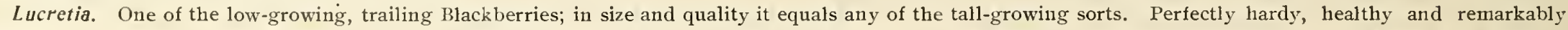

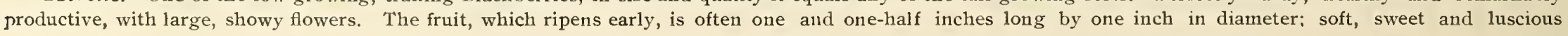




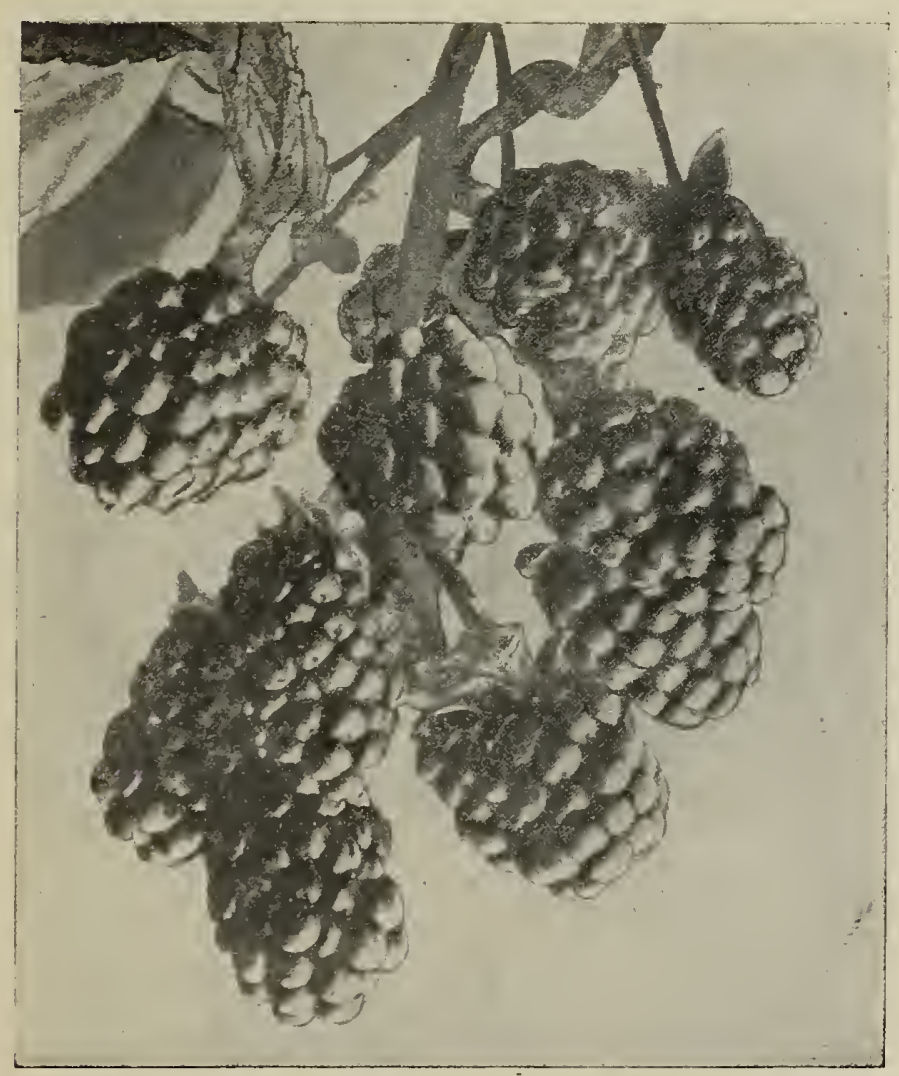

ANCIENT BRITON BLACKBERRY throughout, with no hard core; ripe before late raspberries are gone. Should be mulched to keep berries from ground. We higlly recommend this variety.

Windom. This variety is the one most planter in the North Central states where it has proved to be tlie most hardy. The fruit ripens with the later raspberries and is of large size and good quality. It is very handsone when in blossom. The fruit is superior for cooking, canning and preserves; and if left on the vine until well ripened is one of the best for dessert and will hang on ten days or more after turning black.

IMPROVED DWARF JUNEBERRY. One of the most valuable berries and should be planted on every farm in the West. Its leaves are a dark glossy green, and very much re. senble the pear. The fruit is horne in clusters, like the currant, and ripens in June. Its size equals the wild gooseherry, shape round, color a redish purple at first and becomes a bluisll black when fully ripened. It may be served with sugar and crean1, or cooked as a sauce and is splendid canned for Winter use. It produces fruit in enormous quantities and hears every year. It is also perfectly hardy and needs no special treatnent. Rabbits do not injure it. Set the plants four by six feet apart.

HIGH-BUSH CRANBERRY. Bush closely resembles the snow-ball; perfectly hardy in Northern Minnesota. This shrub bears extremely well; color of fruit bright scarlet; liangs in clusters; ripens in fall and will hang on all Winter. It makes a very fine jelly of a beautiful color. The plant is highly esteemed both for fruit and ornamental purposes.

LOGANBERRY. A combination of the raspberry and blackberry. The berries resemble immense blackberries in form and structure, but are of a deep, reddish-maroon color. In flavor it is exceedingly rich and sprightly, melting and without core. The canes are of strong and vigorous growth, rather dwarf and trailing in habit, with dark green, tough foliage. It roots from the tip, like the dewberries and black caps. Its value is greatly enhanced by its earliness, ripening as it does at the close of the strawberry season and in advance of all but the very earliest of raspberries; yielding abundantly for at least three weeks and perfecting its fruit to full size and flavor.

$S T R A W B E R R Y-R A S P B E R R Y$. This exceedingly unique and attractive fruit is a true raspberry of herbaceous habit and so ornamental as to be worthy of a place in the garden, for its beauty alone. It produces a mass of deep green foliage and large, fragrant, pure white blossoms, followed by immense, brilliant crimson, oblong berries from early June until frost. I11 quality, poor and flavorless when eaten out hand. It preserves well and is very palatable and good when cooked.

BUFFALO BERRY. The hardiest fruit grown; standing the intense cold of the far North (60 degrees below zero). Fruit size and color of Cherry Currants, and 
literally covering the bush to the tips of the branches. Esteemed for pies, jellies, etc. As the plants are male and female several should be planted near each other.

ASPARAGUS. Barr's Mammoth. An old and valuable English sort that is very popular in that country. Like Palmetto, is an improvement on Conover's Colossal and said to be double the size of that variety.

Conover's Colossal. A standard variety of large size, tender and of excellent quality.

Columbian Mammoth White. A distinct variety of strong, vigorous growth, producing very large, white shoots, that in favorable weather remains white until three or four inches high, or as long as fit for use. Market gardeners and those growing for canners will find this a very profitable variety.

Palmetto. A very early variety; even, regular size and of excellent quality.

RHUBARB. Excelsior. A long growing and tender variety, with tender skin. Especially valuable for preserving.

Linnaeus. One of the oldest and best known varieties; strong and productive.

Queen. The extra long, tender stalks are of a decided pink color and is delicious for canning and cooking.

Sweet Wine. A later improvement on Linnaeus. Stalks are much larger and longer. A strong grower and very tender; of splendid flavor.

Victoria. A prominent English market sort; strong and with extra long stems.

HORSE RADISH. This popular plant was introduced to this country from Great Britain at an early date and its cultivation forms an important industry in many sections. It is said that in the vicinity of New York alone more than five hundred acres are devoted to this crop. It is very easily produced in the home garden and anyone who has compared the freshly dug article with that sold over counters can appreciate the value of good, home grown Horse Radish. Roots should be planted in the Spring.

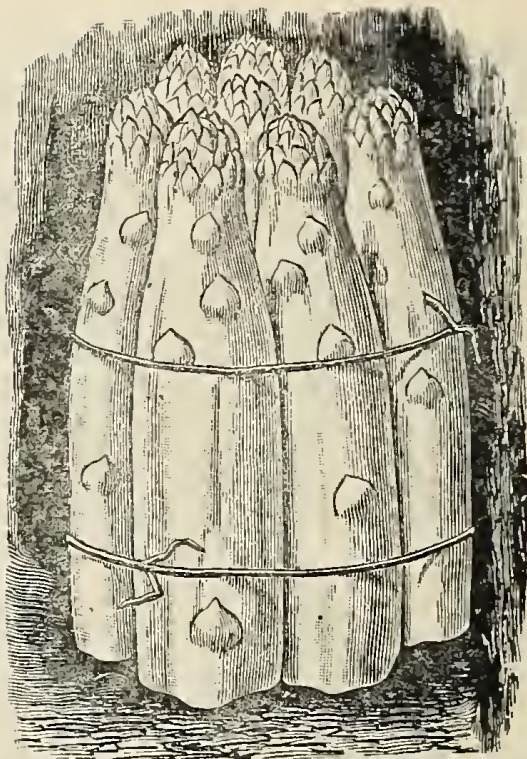

BARR'S MAMMOTH ASPARAGUS

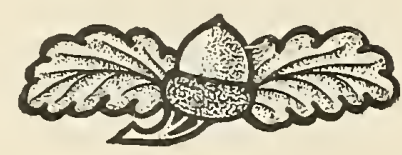




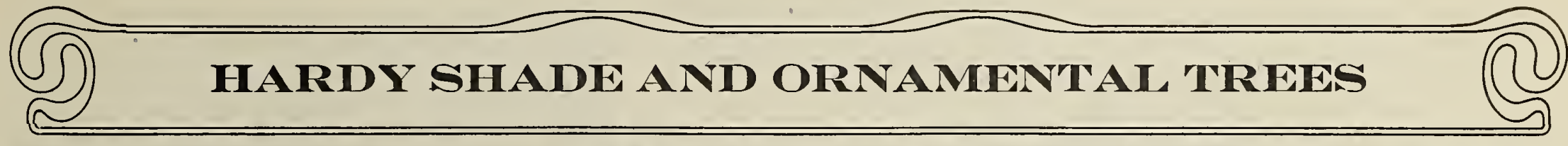

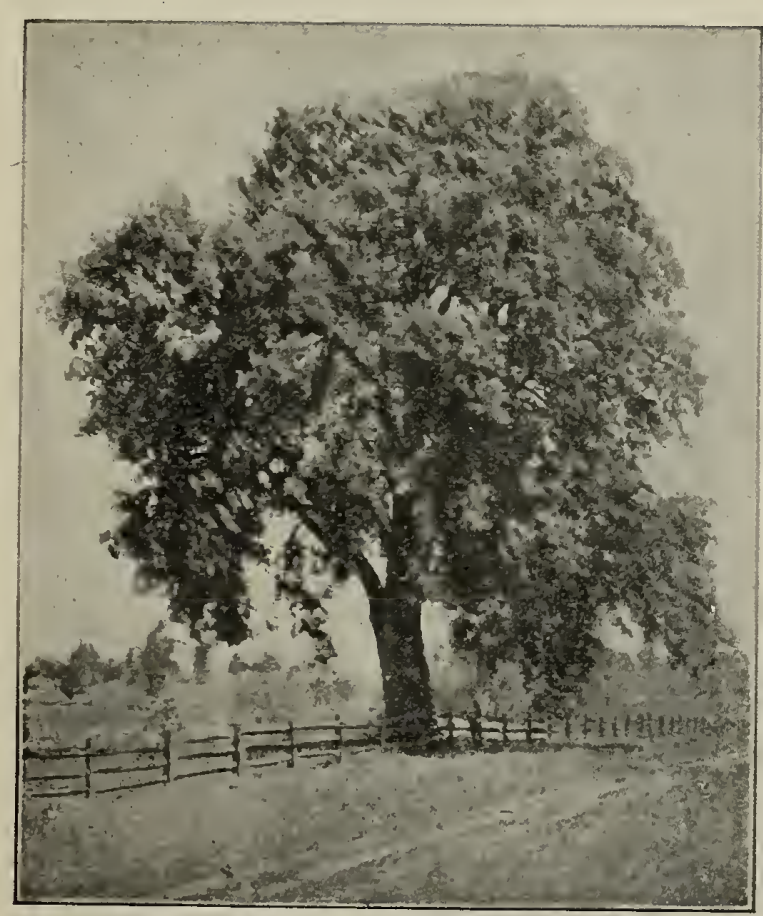

AMERICAN LINDEN

7 HIS department of tree growing is perhaps the most important to the general public as no home, no matter in what country or clime it may be, is complete without surrounding it with stately trees and beautiful flowers. Doubtless you have often observed as you were passing along the street, houses whose general surroundings were so neat and tasty as to attract your special attention. The grounds had been well laid out, the walks and driveways consistently located, the grass kept well shaven, but above all were the grand old shade trees rising here and there, spreading their shapely branches in a protecting way over the beautiful grounds. You look at the great Elm trees trying, as it were, to surpass in stateliness and granduer the magnificent Oaks; the shapely Maples so beautifully formed and symetrically lieaded; the attractive Catalpas and Lindens exposing their broad leaved foliage to the breeze, forming a magnificent contrast to their imposing neighbors. Then there was the flowering shrubbery in the corners and on the inside curves of the walks and drives, just as if the walks were built around them. The Evergreen hedge produced a natural border-for the lawn and shut off the view from the background. Then there were the bright colored flowers, the climbers on the porch oue linking with the other to forn1 a spectacle most pleasing to the eye. All these fine trees and flowers you say make the home nore beautiful; certainly they do, but someone had to plant them or they would not be there. Perhaps $\$ 50$ originally purchased the entire lot of trees, but now their value could hardly be estimated and if one were to purchase this place, he would expect to pay roundly for the improvements. The up-to-date farmer or owner of city property knows that a well kept lawn, nice shade trees and good windbreaks add not only to the beauty of

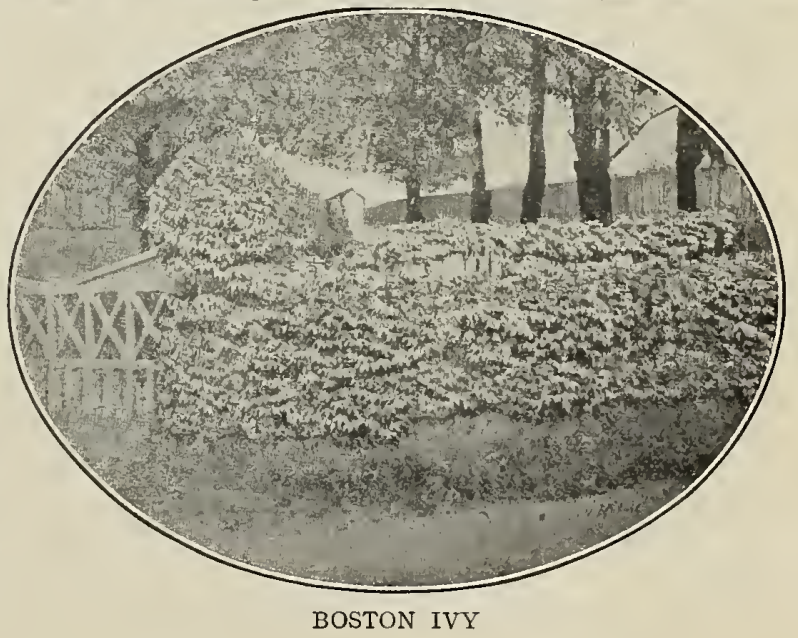


the place but to the cash value as ivell. In planting, make a careful selection of the trees that will group well together and give a pleasant view to the landscape. If you do not know just how to do this, send us a sketch of your place and about how much you wish to expend; we may be able to suggest something that will help you out in the matter.

\section{Landscape Architecture}

We have made a careful study of this subject and are prepared to advise free of charge those desiring to to inprove their homes. We have in our employ, expert landscape architects who make a specialty of this work. Their practical knowledge and long experience in landscape gardening enables us to submit plans and plats for new grounds and parks at a very reasonable figure. Our landscape gardeners will personally supervise sucli work when desired.

\section{List of Trees Recommended for Various Purposes}

For Streets, Roads and wirle Avenues-An1erican Fim, Sugar and Silver Maple, Carolina Poplar, Norway Maple, Box Elder.

For Driveways through Lawns ancl Parks-Norway Maple, Catalpa Speciosa, An1ericai1 Linde11, Horse Chestnut, Laurel Leaf Willow.

Single specinens of large growtli to be branclied from the ground-Birclies (particularly Cut-Leaf Weeping). Anerican Linden, Norway, Sycanıre and Cut-Leaf Maples, Horse Chestuut, Austria11, White and Scotch Pines, Norwar, Colorado and White Spruces.

Single specimens of medium growth to be branclied fron the ground-Horse Chestnut, I aurel Leaf Willow, Oak Leaf Mountain Ash, Hemlock, White Pines, Arborvitae.

Trees that thrive in 1110ist locations-American Elm, An1erican Linden, Asl, Catalpa, Poplars, Box Elders and Willows

Trees that thrive on dry knolls or poor soil-Silver Leaf Maples, Poplars and Box Elders.

Flowering Trees-Fringe Tree, (white and purple), Lindens, Horse Chestnuts, Catalpa Speciosa, Cherry (white).

Cut Leaved Trees-Cut Leaved Birclı, Wier's Cut Leaved Maple, Imperial Cut Leaved Alder.

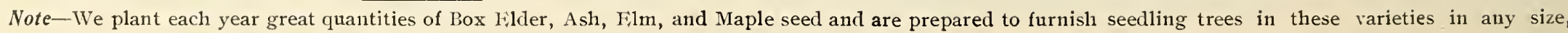




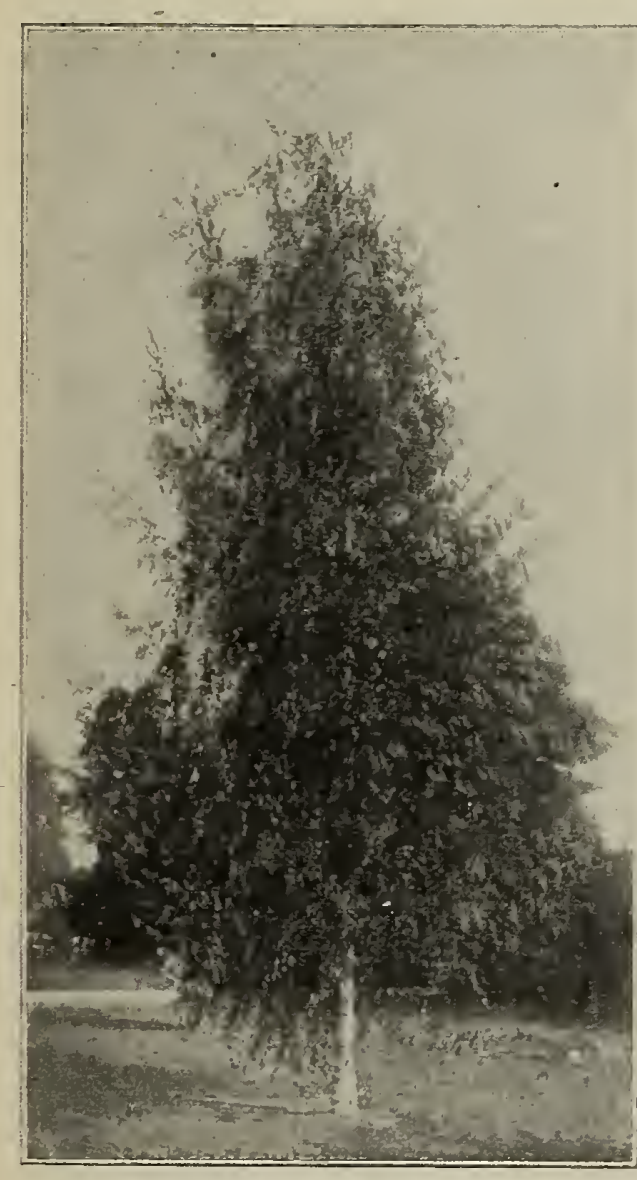

EUROPEAN WHITE BIRCH especially 18 and 24 inch sizes. We ship these out in hundred and thousand lots for timber and windbreak purposes. We also grow all kinds of Poplars and Willows from cuttings and can furnish these rooted in any size.

\section{E C D UOUS TRE ES}

Alder, Imperial Cut Leaved. A very striking and beautiful tree with-large and deep cut foliage. Very hardy and vigorous. Filegant.

$\mathscr{A}$ sh, American White. A rapid 'growing native tree, of fine symmetrical outline; a valuable street or park tree; shonld be extensively planted for timber. Thrives better than any other in North and South Dakota.

$\mathscr{A s h}$, Green. A fine tree for general planting. It is a native of Minnesota and seeds very freely.

$B$ eech, American. A very beautiful lawn tree with silvery bark, fine spreadiug growth and symmetrical rounded head. Fispecially attractive in the Spring, with the tender delicate green of its leaves and pendant flowers. Pure yellow in Fall

Beech, Purple Leaved. Makes an elegant medium sized tree for the lawn. The foliage in the Spring is a deed purple, later changing to crimson and in Autumn a dull purplish green.

Birch, Paper or Canoe. One of the handsomest trees in cuitivation and a vigorous grower. When young the hark is dull brown, but clianges as the tree grows older, to a shining, silky white, rendering it clean looking and attractive.

Birch, Furopean White. A distinct, native species of vigorons, rapid growth. Bark white, leaves triangular, tapering and pointed. It is very hardy and will grow in sandy or rocky soil in any climate.

Box Elder (Ash Leaved Maple). This species is easily distinguished by its pinnate leaves and greenish yellow bark. It grows rapidly into a large,

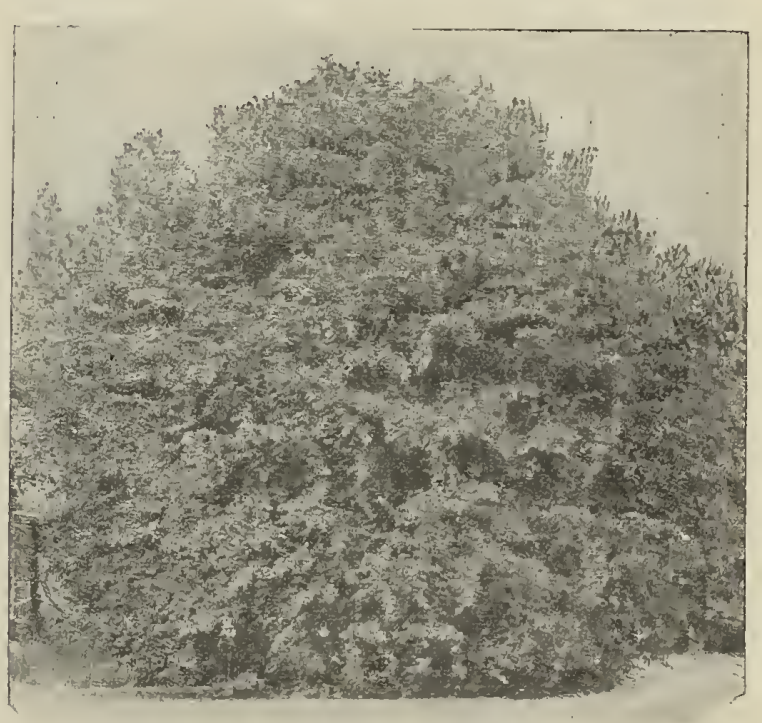

PURPLE LEAVED BEECH 


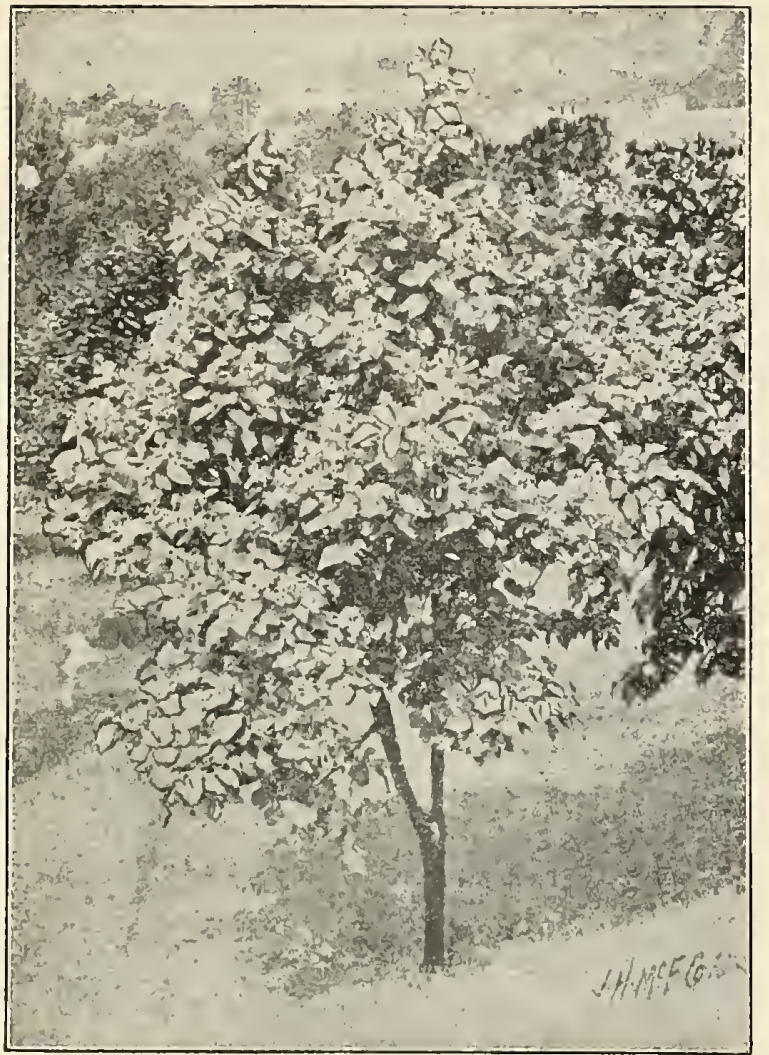

CATALPA SPECIOSA

spreading tree, found valuable for planting timber claims, shelter belts, etc, in the West where it endures both drouth and cold. One of the hardiest and best trees for Western prairies.

Catalpa Bungei. A species from China. Of dwarf habit, growing only three or four feet high. When grafted on stems seven to eight feet high, it forms a perfect umbrella shaped tree. Not perfectly bardy in this latitude.

Catalpa, Speciosa. This hardy native variety is one of the finest for shade and ornamental purposes in our list. The leaves are large, heart shaped, beautifully ribbed, never subject to the attack of insects, and at all times clean, vigorous and beautiful.

Cherry, European Bird. A pretty, medium sized tree with glossy leaves and long clusters of white flowers in May. These are followed by black fruits, loved by all the birds. One of the earliest trees to leaf out in Spring.

Cherry, Black. A tree of rapid growth, the lumber of which is very valuable. This tree should be much more cultivated than it is.

Crab, Wild. This is our native crab and is very hardy. Tree seldom grows more tlitn twelve feet high, witl rounderl top and bright pink blossoms. Very heautiful while in bloon.

Crab, Double Hlowering (Bechtel's). Makes a medium sized tree; perfectly hardy, succeeds well in all soils, not extrenely wet. When in bloom appears to be covered $\mathrm{w}$ ith delicate, pink, perfectly double small roses of delicious fragrance. The only sweet scented double crab.

Dogwood, White Flowering. The great, white flowers are three inches and more in width, lasting in favorable weather for as many weeks. Besides these fine characteristics the bright red bark in its young growth makes it attractive and cheery in Winter. Blooms when small.

Elm, American Wbite. This is the noble spreading and drooping tree of our own forests, than which there is no finer tree for street and park planting.

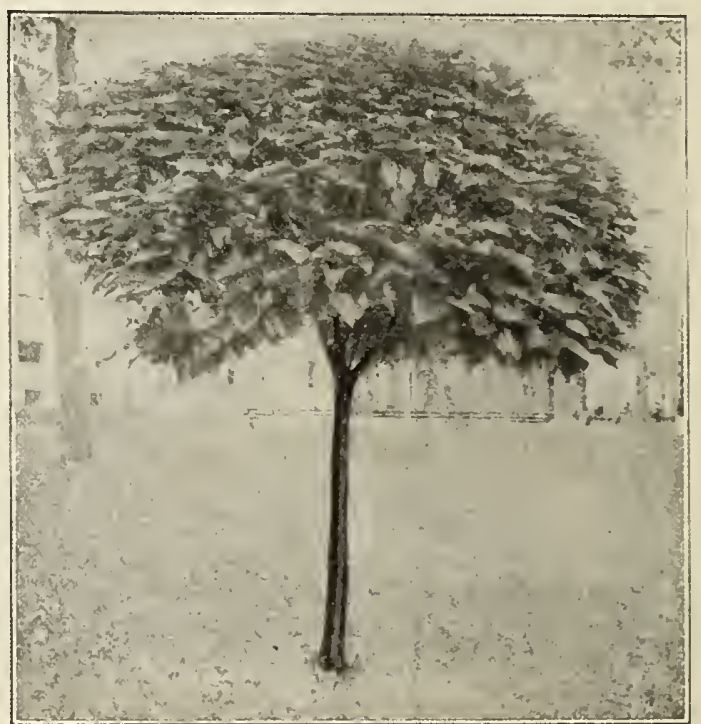

CATALPA BUNGEI 


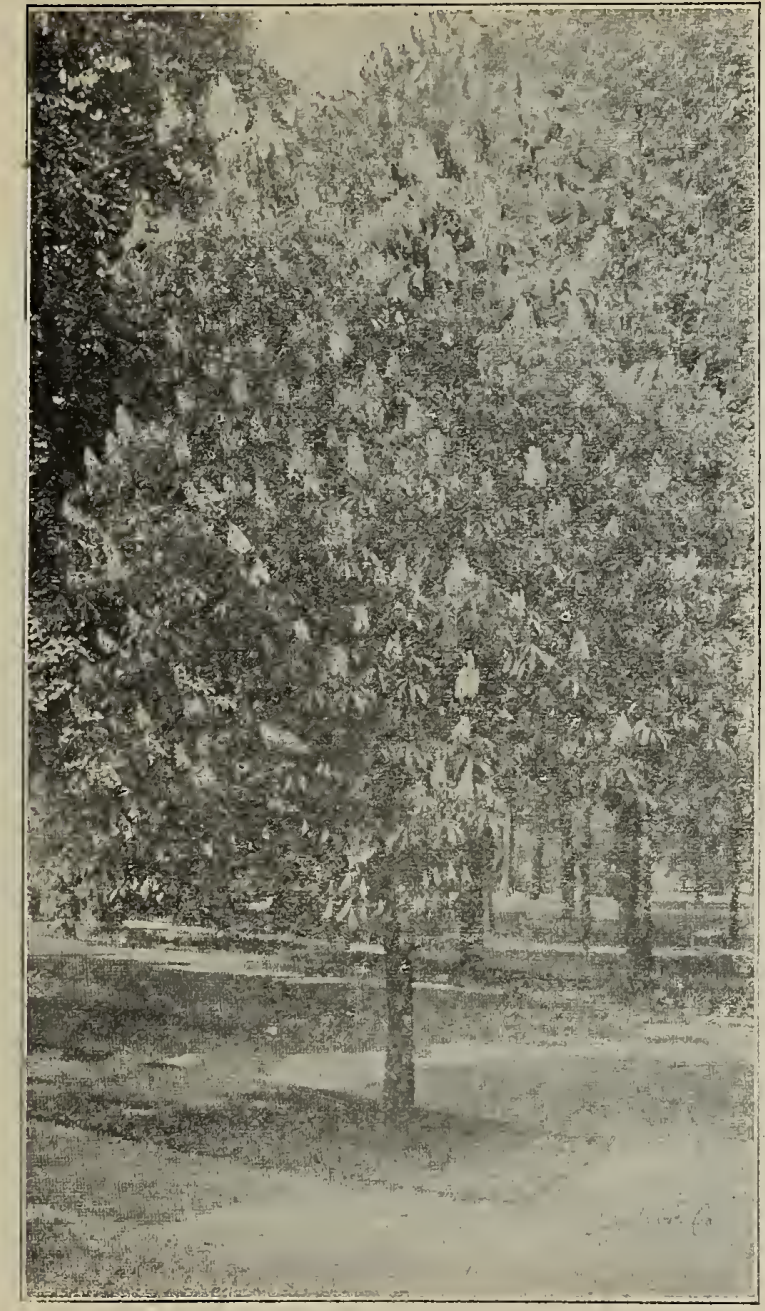

HORSE CHESTNUT
Hackberry. A very handsome native tree, of easy, rapid growth and great vigor. Bears transplanting well. The character of the growth is similar to the elm, though the top is not quite so spreading as that variety. It grous more rapidly, soon forming a large tree.

Horse Chestnut. This tree has an elegant pyramidal form with large, deep lobed leaves and showy upright pinacles of red or white flowers. Tree hardy, vigorous and free from insect pests. This is among the first trees to unfold its leaves in Spring.

Larch, European. An excellent rapid growing, pyramidal shaped, dro?ping shade tree; drooping, slender branches; foliage light green, soft and graceful. Perfectly hardj and thrives in nearly all situations. Makes liandsome specimens for ornamental purposes.

Linden, American (Basswood). A rapid growing, large sized tree with a remarkably straight trunk, deep green heart shaped leaves, and clusters of fragrant yellow flowers, will grow almost anywhere. Valuable for its wood, and makes a handsome shade tree.

Locust, Black. This is the common form of Locust grown through the Central West. Rather a slow growing, hard wooded tree, with yellow or white flowers, borne in long pendulous racemes. Flowers fragrant wood durable as post timber.

Maple, Norway. A tree of foreign origin, a sturdy and

57

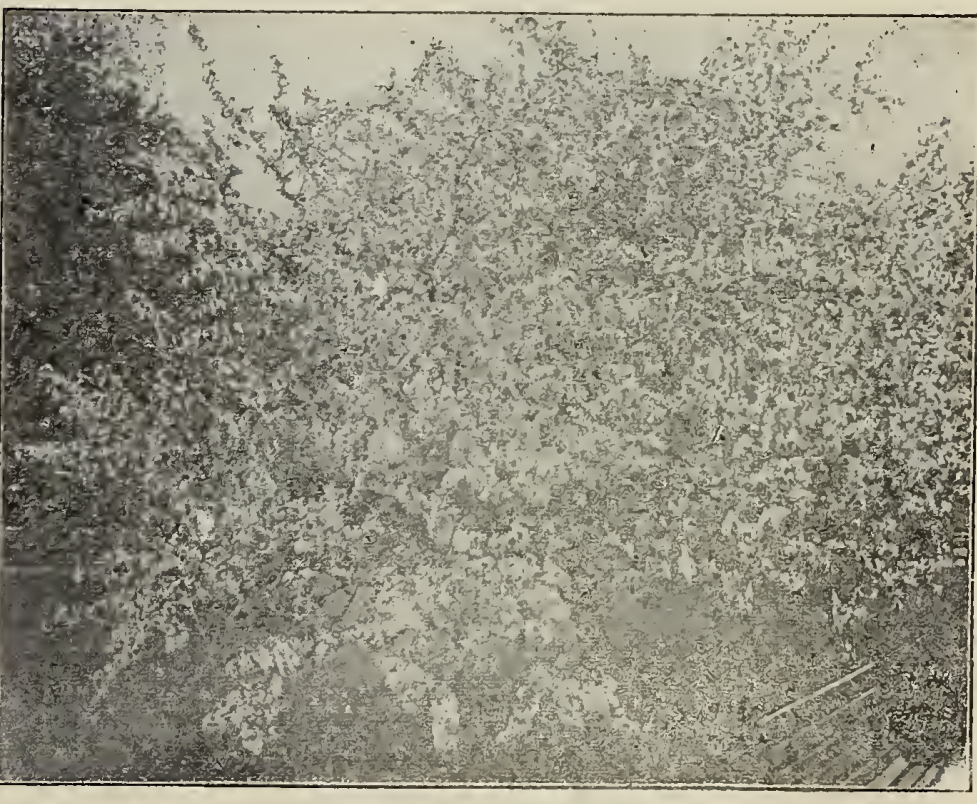

EUROPEAN BIRD CHERRY 


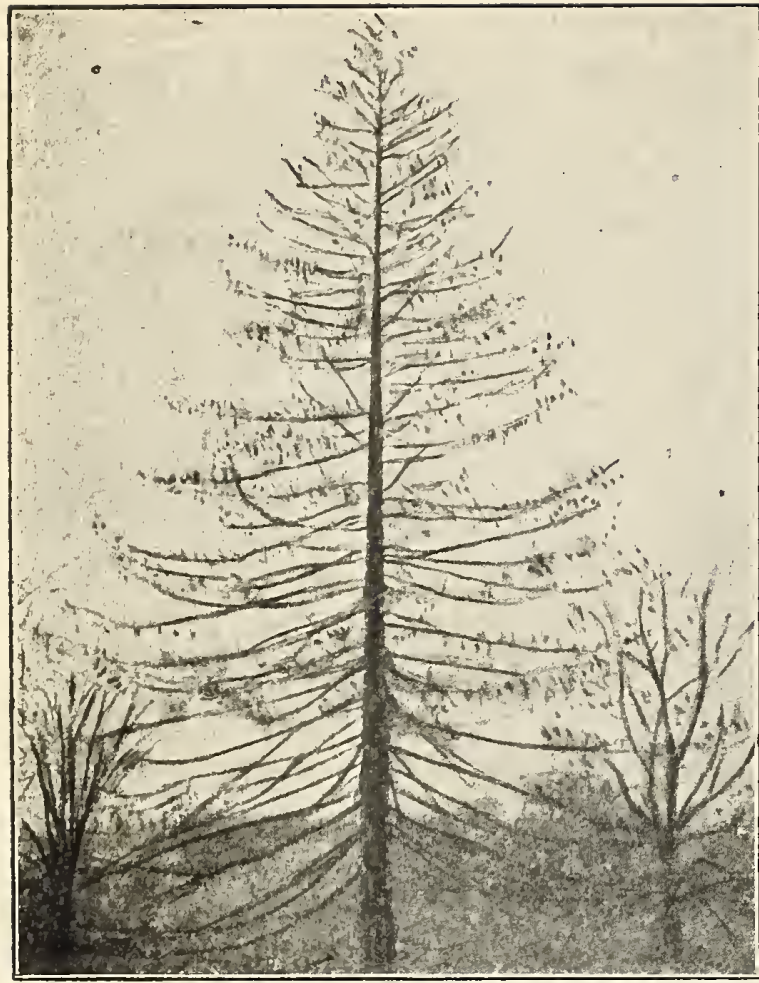

EUROPEAN LARCH

symetrical grower, forming a broad, spreading, rounded head. The leaves are deep green, large and broad and cling to the branches longer than other sorts. Fixcellently adapted to st eet planting.

Maple, Silver or Soft Maple. A magnificent shade and ornamental tree of rapid growth. It is perfectly hardy and will thrive in any soil and any locality. The leaves are beautifully shaped and have a silvery gleam. The hardiness and ease of culture of this tree makes it one of the nost desirable for street and park planting.

Maple, Sugar or Rock. A valuable tree for sugar as well as lumber, sharle and ornament. It is adaptable to all locations. Roots deeply and grows symetrically into a tree of large proportions.

Maple, Weir's Cut Leaf. A very beautiful silver leaf sort with delicately cut leaves and distinct half drooping habit. It grows rapidly, forming a straight, upright trunk with slender branches that curve gracefully downward.

Mountain Ash, European. A fine, hardy tree; head dense and regular, covered from July to Winter with large clusters of bright scarlet berries.

Mountain Ash. Oak Leaved. A variety with large hoary lobed leaves; distinct and fine.

Mulberry, Russian. Is largely planted for screens and wind-breaks, also used for sharle trees. The fruit, which is rather small, is greatly appreciated by the birds and fowls.

Oak, White. Grandest of its genus and of our American trees. A spreading, towering species, with rugged, massive trunk and branches. The deeply lobed leaves change to dark crimson in Fall.

'Pin Oak. Almost pyramidal in shape, sometimes described as lialf-weeping when old, because its lower branches almost touch the ground. It grows faster and developes the family characteristics earlier than most oaks. The leaves are deep glossy green and finely divided. Orange-scarlet in Fall.

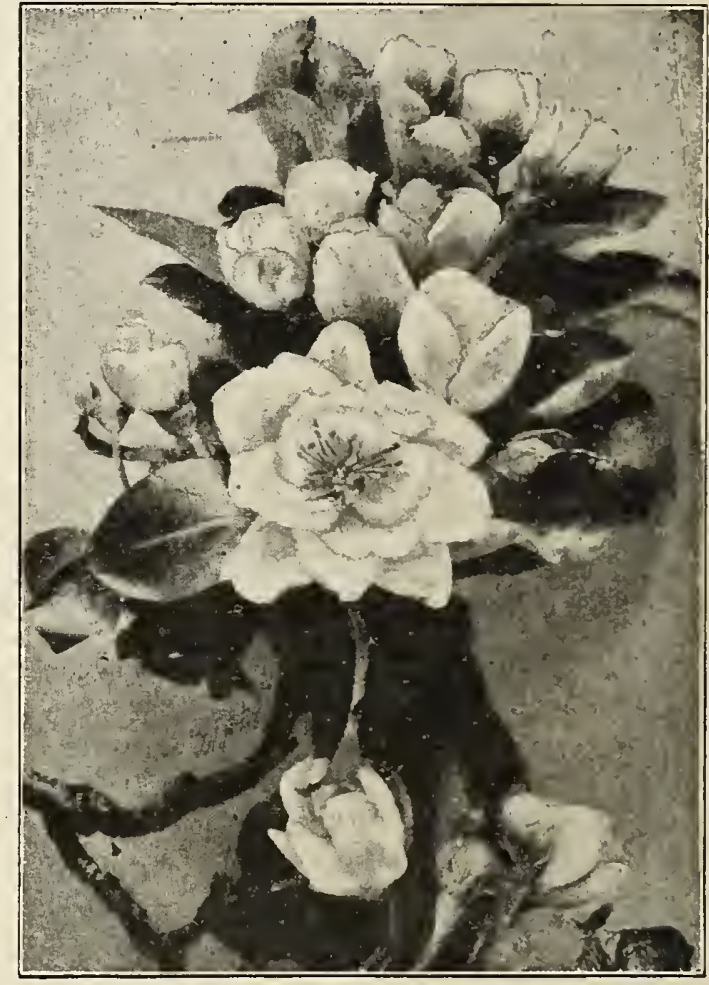

FLOWERS OF BECHTEL'S FLOWERING CRAB 


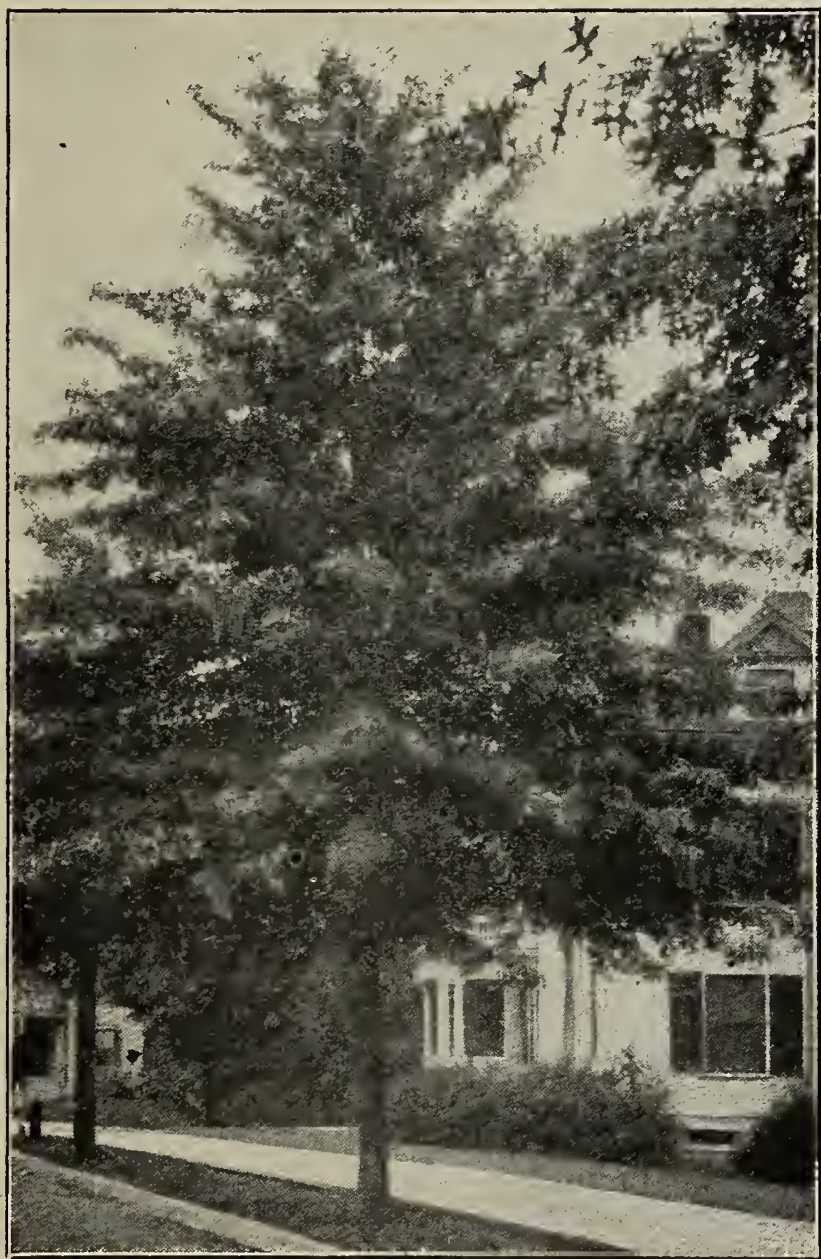

PIN OAK

Poplar, Balsam or Balm of Gilead. A handsome native with thick, dark, ovate leaves, silvery beneath. The spicy gum of the buds is used medicinally.

Poplar, Carolina. Unexcelled for quick growth and effect. Its rapid growth giving an air of luxuriance to places where other trees appear starved. Showy and cheery from the constant movement of its glossy, silver lined leaves, yet always casting a dense, cool shade. If well pruned back during the first few seasons, it makes a strong durable tree. Is yearly planted in great numbers and is one of the most popular street trees. In some cities it is planted almost exclusively when opening up new streets in residence sections. The Carolina Poplar promises to be to the north what the Eucalyptus is to the South and is by far the most rapid grower we have. These trees have been known to grow 55 feet tall in fourteen years with good care. They do not, like many others, waste their energy on side limbs. It retains its size as it mounts upward and thus produces more lumber than any other. It outgrows the Cottonwood and Asiatic Poplar and in a succession of dry years will survive them all. The tree is well adapted to Minnesota and the Dakotas and has also thrived well in Manitoba and Saskatchewan, Canada; of course, it does best in deep rich loam. We are an impatient people and want to reap a harvest in a year, but we can stretch our patience a little and plant with the hope of having a tree that will cut from 100 to 300 feet of lumber in 12 years. Lumber is becoming scarcer and higher priced each year and there is no doubt but what Carolina Poplar lumber will be worth $\$ 30$ to $\$ 40$ per $\mathrm{M}$ in 12 years' time.

Poplar, Cottonwood. A tall native tree with large shining leaves, attaining a height of 80 to 100 feet. Grows very rapidly and is very hardy, thriving under most adverse conditions.

Poplar, Lombardy. Of obelisk form, growing rapidly to extravagant heights. Forms striking lawn groups; is much used for tall screen-hedges. Always makes a striking feature in any landscape.

Poplar, Russian. This tree closely resembles the Carolina Poplar but is of slower growth and is claimed by some to be hardier. A very fine wind-break tree.

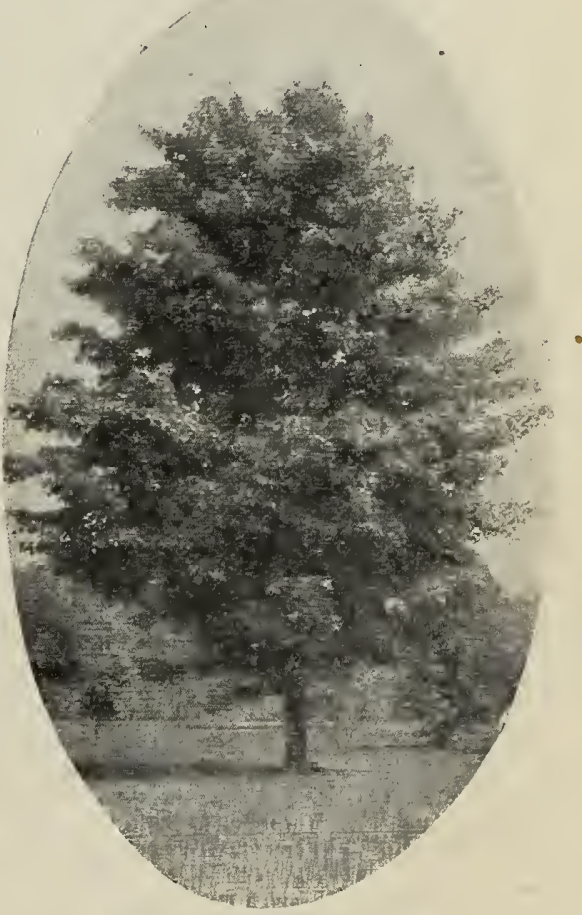

SUGAR OR ROCK MAPLE 


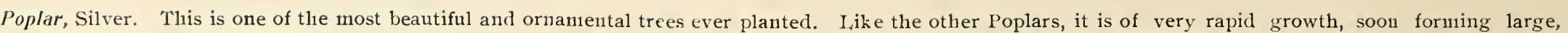

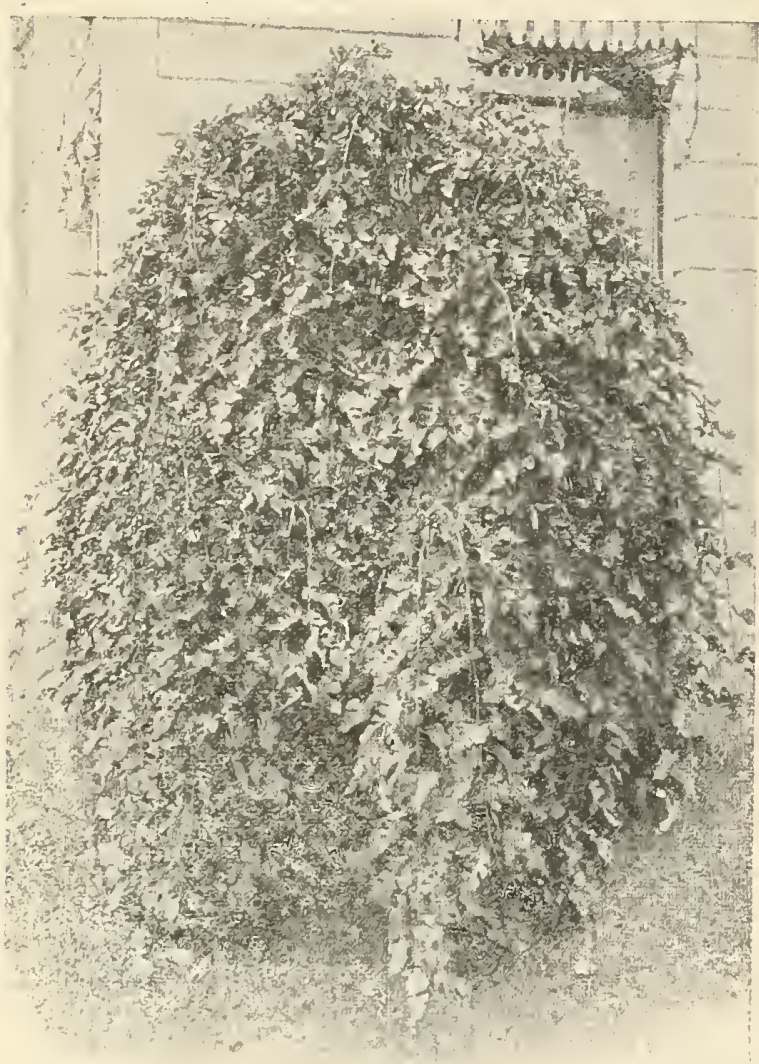
shapely trees. This variety is of more spreading growth than the others and by careful training, forms large, rounded heads of great beauty.

Sumac. A beautiful, low variety with leaves of large size, deeply cut and drooping gracefully from the branclies. Autumnal color, a rich red.

Willow, American White. A very fast growing and hardy tree for the Northwest. Makes a very effective wind break and is generally planted where quick results are desired.

Willow, Golden. A showy variety with golden bark of high color, making it very conspicuous during Winter. A handsonie tree at all seasons. Very hardy.

Willow, Laurel Leaved. A splendid ornamental tree with large, glossy laurel-like leaves, hence its, nanie. Makes a beautiful park tree and is much used for screen hedges.

\section{TV EE I I Y G TREES}

Beech, Weeping. A large, luxuriant tree of curious irregular growth. Its sparkling masses of foliage are swept by tortuous branclies into fountain-like masses of green; wonderfully rich and graceful in effect.

Birch, Cut Leaved. This is one of the nost beautiful and desirable trees for the lawn ever introduced. The branches are of graceful, drooping labit with foliage delicately cut and very fine. The bark is silvery white forming a beautiful contrast with the foliage. It makes a rapid growth and is perfectly hardy in all sections of this country.

$E / m$, Camperdown. Of fine and notable hahit, the stout branches often sweeping out horizontally for several feet before they curve downward, making a broad, handsome tree.

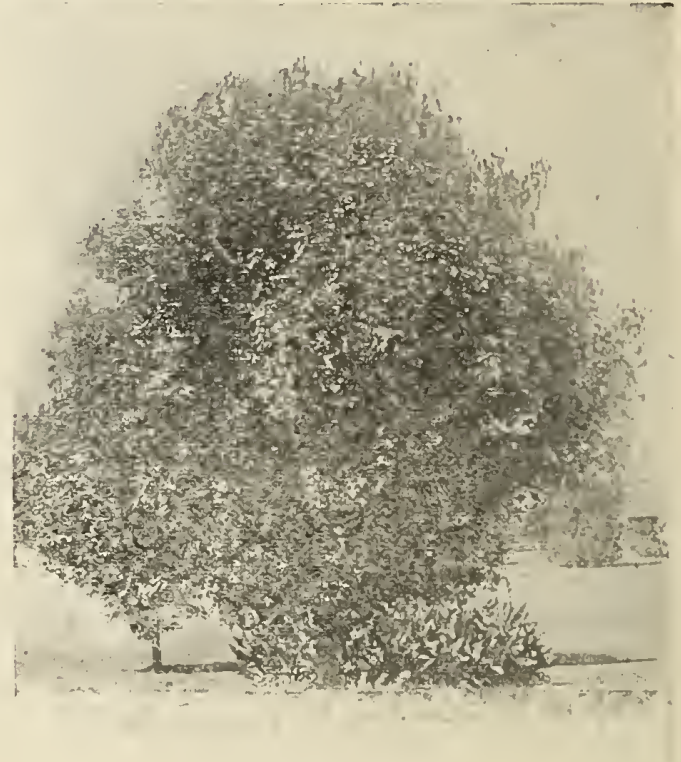

NORWAY MAPLE 
Mountain $A s h$, Weeping. A beautiful tree of hardy, vigorous growth, with straggling, pendant branches, turning and twisting in all directions, in a few years forming an immense head with branches resting on the ground and producing a very pleasing effect. It has clusters of very fragrant, feathery blossoms, whicl, as the season advances, ripens into scarlet berries.

Mulberry, Tea's Weeping Russian. One of the most graceful and beautiful of the hardy weeping trees, and it is wholly unique, having a perfect unibrella-shaped head and slender willowy branches drooping to the ground as do the vines of a hanging basket. The foliage is glossy, green and with delicacy of form and motion, it con1bines health and vigor being innured to heat and drouth. Admirably adapted to cemetery planting.

Willow, Kilmarnock Weeping. Unique in form and vigorous in all soils. This willow has been widely desseminted. It is usually grafted 5-7 feet high on stout stems and then forms a cone of glossy foliage.

Willow, Wisconsin Weeping. A tall, fine, drooping tree with slender branchlets. Very hardy.

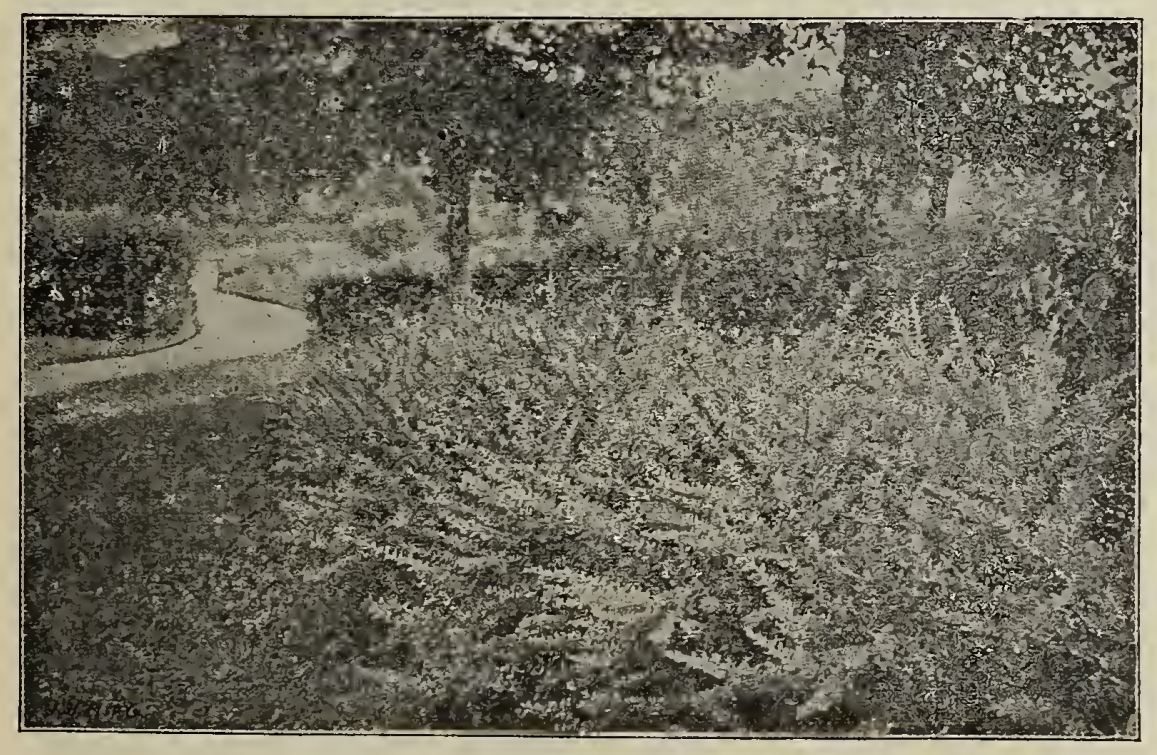

BARBERRY
H IE D ES AND S C R E IE N S

We receive so many inquiries for suitable slirubs for planting as permanent hedges or screens that we are induced to make special mention of a few of the most useful and ornamental sorts. These can be furnished in sizes practical for such purposes. By using medium sized plants, a hedge can be made as clieaply as a good board fence and then with a little care it becomes every year more and more a thing of beauty. Such hedges continue as a principal attraction in our best kept places.

Barberry. The Barberries are our most interesting fanily of shrubs, varying froin two to six feet in height, rich in variety of leaf, flower ancl habit; very effective in'groups or masses or planterl by themselves. Generally used for hedge purposes. See illustration on this page.

Buckthorn. One of the hardiest hedge plants for the Nortliwest. It stands 


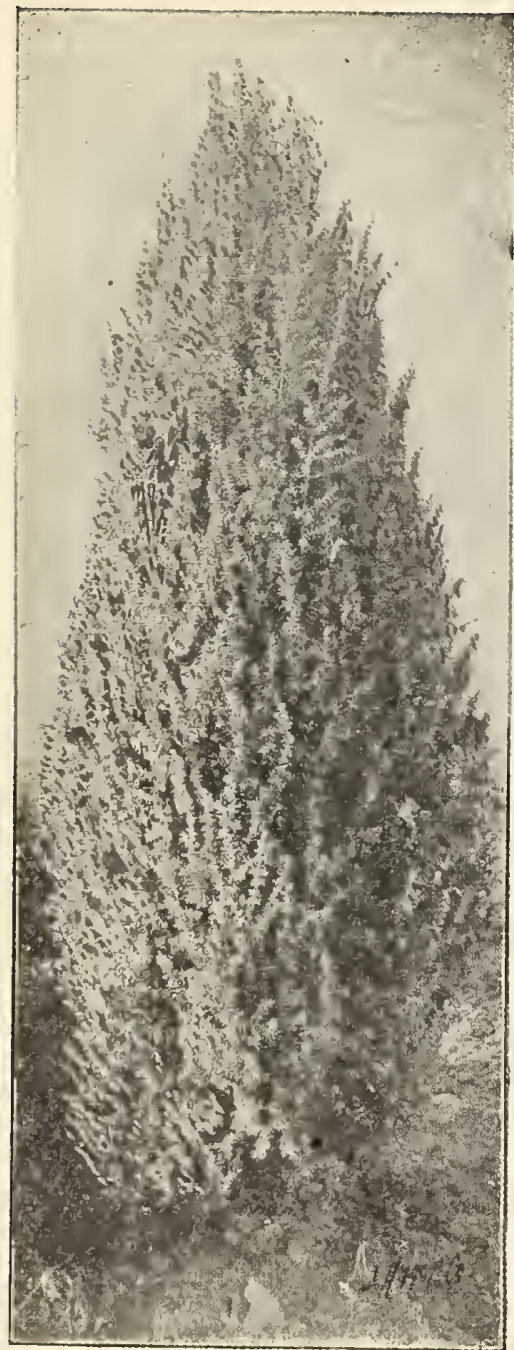

our cold Winters without a particle of injury. Starts early in the Spring and retains its foliage until frost time. When properly trimmed it makes a very tight hedge and is very desirable on this account.

Caragana SAborescens, (Siberian Pea Tree). A hardy variety from Northwestern Russia. Extensively planted in Manitoba and the Dakotas for hedges.

Honey Locust. This is considered in many sections as one of the best hedge plants. It is of vigorous growth, perfectly hardy, thrives with ordinary care and on account of its thorny nature is well adapted to farm planting.

Honeysuckle Tartarian. This is the popular old time variety often used for hedging and comes in three colors of fragrant flowers, white, pink and red. Makes a very effective hedge and is extremely hardy.

Privet. An excellent plant for ornamental hedges. It makes rapid growth and is easily trained and cared for. The foliage is bright and clean and in early Summer the plant is covered with tiny white blossoms.

Russian Olive, (Oleastor). Native of Russia, was brought to South Dakota by the Russian Menonites a number of years ago and has been largely planted by them for shade, ornamental and hedges, being especially adapted for a cold, dry climate. It very often attains a height of thirty feet. Small yellow blossoms appear the latter part of June and are remarkable for their spicy fragrance. Makes a fine hedge plant for North Dakota.

\section{EVERGRENNS}

Nursery-grown Evergreens transplant as easily as any class of tree. Young trees, or those moderate or small size, are the most certain and profitable to remove. Thorough culture and mulching are very useful, especially in dry seasons. Farly Spring planting we have found the best, but they can be safely removed in wet seasons quite late, or until the new shoots are started. In planting, tramp the earth firmly, but carefully, on the roots; the importance of this can be scarcely overstated. In transplanting, the roots should never be exposed to the sun and air a single minute. Evergreens are superb for screens or windbreaks, around buildings, orchards and stock corrals. Norway Spruce, White and Scotch Pine, Austrian Pine and Arbor Vitae, are all admirable for that purpose. The last two named for low screens should be planted 18 inches apart, and clipped twice each year, while young, in June and

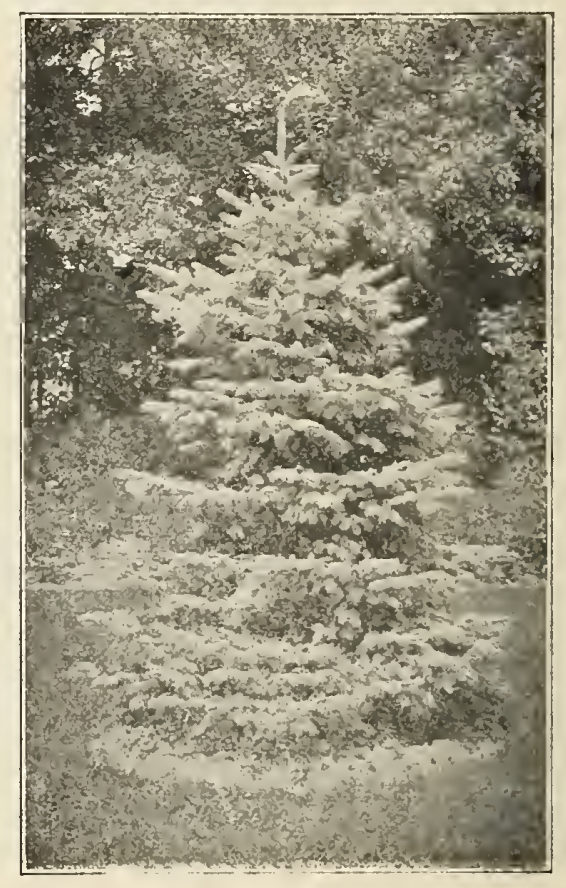

COLORADO BLUE SPRUCE 


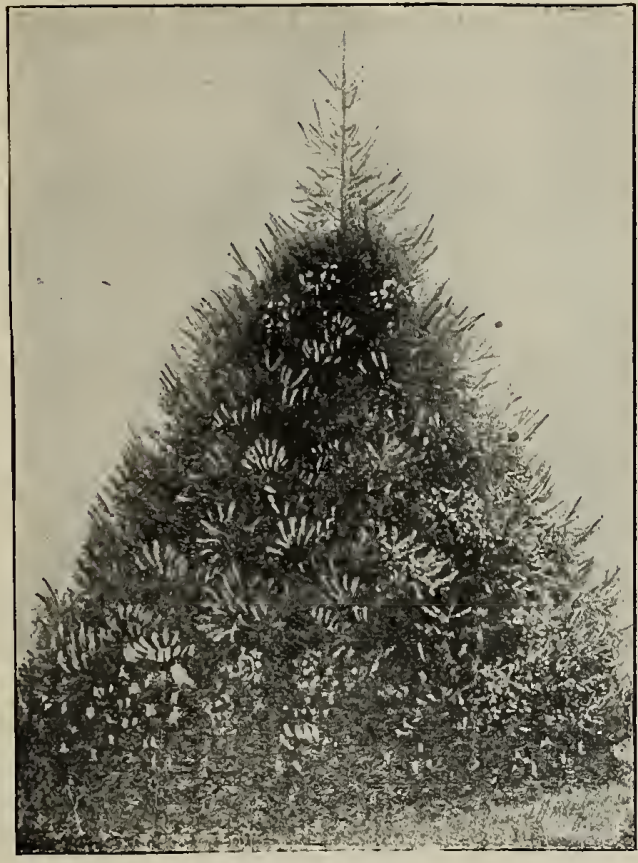

NORWAY SPRUCE

A ugust. For high screens, plant two or more rows, 10 to $12 \mathrm{ft}$. apart, $12 \mathrm{ft}$. to the row, each tree opposite the center of the space in the next row. Fvergreens should be allowed to branch out near the ground. Pruning should be done before they start in the Spring and to thicken up Evergreens rapidly, clip off the ends of the young, succulent shoots while they are soft and tender.

Arbor Vitae, American or White Cedar. This is a native tree, known as White Cedar, Excellent for screens and hedges and makes a fine lawn tree. Habit, upright, much inclined to branch and form more than one trunk. One of the best for ornamental hedging.

Arbor Vitae, Golden. Same form and hahits as the American Arbor Vitae, but with bright, yellow foliage on new growth. Very ornamental.

Austrian Pine. A hard $\Lambda$, rapid growing tree, very desirable for windbreak purposes.

Cedar, Colorado Silver. This is a very beautiful tree with silver foliage. By many regarded as more beautiful than the Colorado Blue Spruce. A native of Colorado.

Fir, Balsam. Tree conical in form, foliage deep green. A very symetrical tree and very beautiful while young but inclined to shed its small branches and become scrubby and naked before it arrives at any considerable age.

Fir, Concolor, (White Silver). An elegant, picturesque Colorado species; long, leathery leaves, with glaucious tinge when young, becoming pale green with age. Branches arranged in horizontal whorls. One of the brightest and best of Evergreens.

Hemlock. Sometimes called Weeping Spruce. Not considered hardy where exposed to extreme temperature.

Juniper, Irish. Similar to Red Cedar in foliage. 'Top very symetrical and narrow. One of the most beautiful Evergreens and highly recommended by many planters.

Juniper, Savin. A low, spreading tree, with handsome, dark green foliage; very hardy and suitable for lawns and cemetaries. Can be pruned to any desired shape.

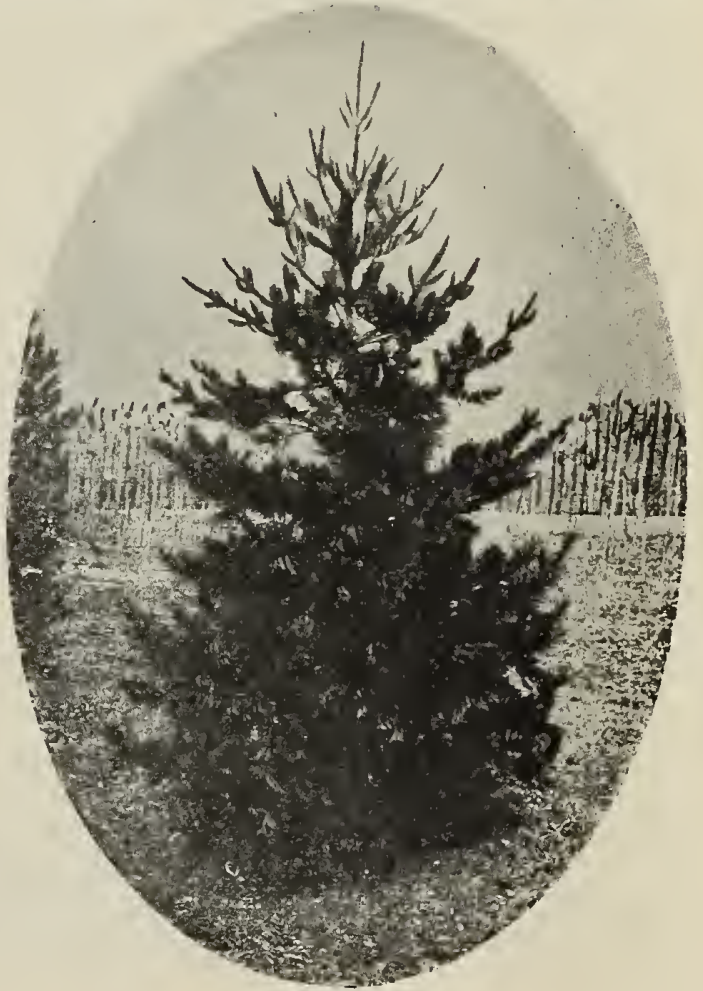

WHITE PINE 


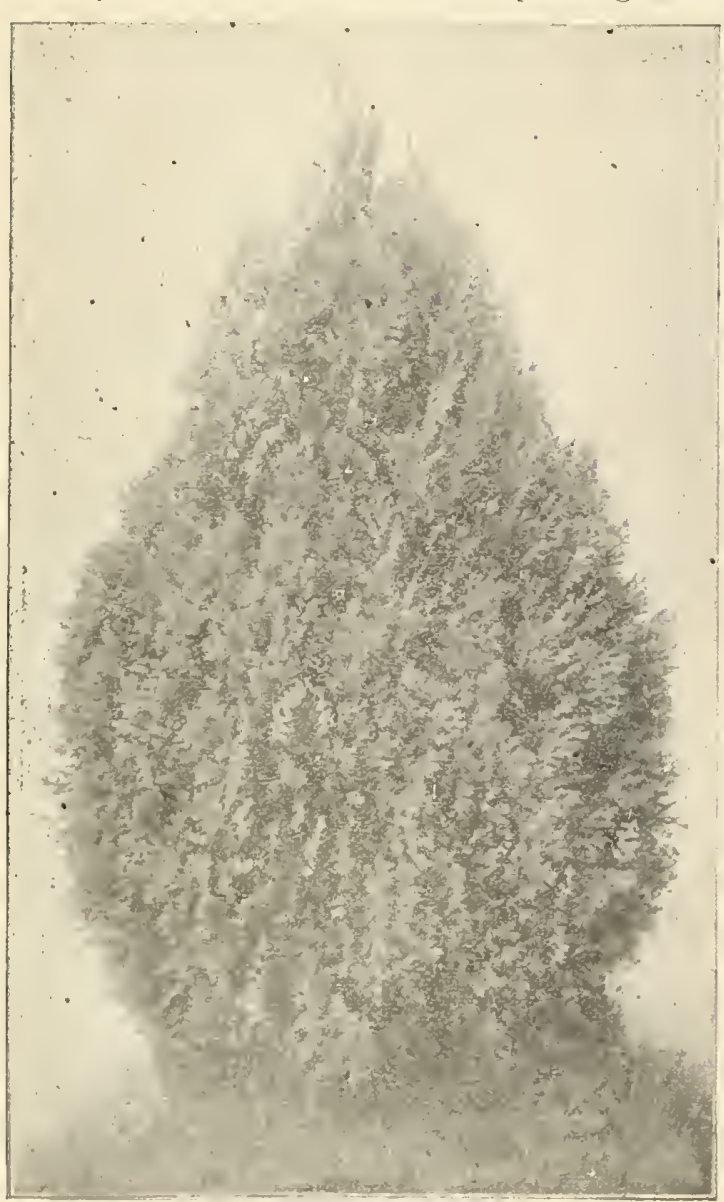

GOLDEN ARBOR VITAE the best for lawn purposes.

Pine, Ponderosa. Highly prized in extreme northern sections on account- of its rapid growth and hardiness, leaves long and silvery. A Rocky Mountain species.

Pine, Scotch. A fine; robust rapidly growing tree, with stout erect shoots and silver-green foliage.

Pine, Jack. The mostrugged of eleven varieties of evers"eens. Best evergreens grown in severe locations. Valuab!e for windbreak purposes.

Pine, White. A very rapid, upright growing tree; foliage fine and soft. The nost ornamental of all Pines and much used for timber purposes.

Spruce, Colorado Blue. A tree of exceedingly great beauty from the Rocky Mountains, where it is found growing in very severe exposures. The tree is of regular habit and lighlly ornannental. Has proved hardy in every way.

Spruce, Norway. Conical in form, color bright green; foliage sharp pointed; an excellent tree for windbreaks and ornamental purposes.

Spruce, White. This is the most beautiful of all the Spruce fanily. In sliape it differs very little from the Balsam Fir, when young, but is broader at tle base when large. Tree extremely hardy, of noderate growtl and holds its beauty longer than any other Evergreen known.

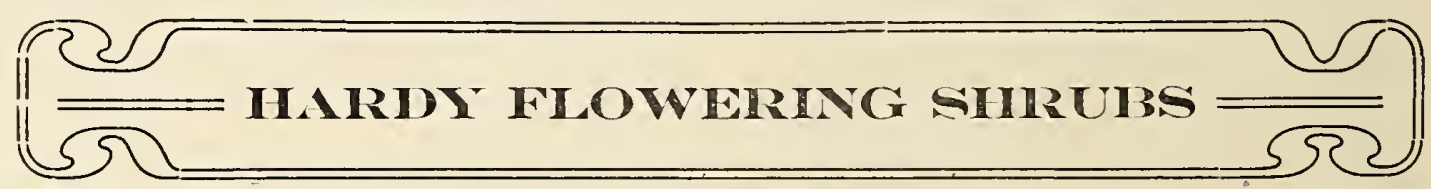

T. OTHING adds more to the beauty of a place than to have the sides and background well filled with 1 nicely arranged groups of shrubbery. Until seen, no one ca: appreciate the effect that can be brouglit out by properly arranging and grouping the wonderful assortment of foilage, ranging in color from the darkest green and purple to light orange and silver tints. Arlded to this the great variety in blossoms unite to keep up a never failing interest. On large lawns, shrubbery should be set with the high-growing varieties on the back or in the center and the lower-growing in front or around. 'The Lilacs (purple and white), with the Weigelias and Syringas make a beautiful group. The Tartarian Ioneysuckle (pink and white), and the Hydrangea Panculate Grandiflora, which is as bardy as a Snowball, are fine specimen shrubs for the lawn, handsome when not in flower and always giving very good returns for a little care: The different Spireas are especially lesirable for completing the blooning season. With 
regard to pruning slirubs, every plant, tree and shrub has its own liabit of growtli and this distinctive feature is its attraction, so do not try to prune them all alike, but simply remove dead branches and try to preserve as nearly as possible, the peculiarities of habit and foliage. The Weigelias, Deutzias and Syringas (Mock Orange) flower on the wood of the preceeding year's growth, lience these shrubs sliould not be pruned in the Wiuter or Spring, but after they are through flowering, when the old woorl should be shortened or cut out, thus promoting the growth of the young wood which is to flower another year. Spireas, Lilacs

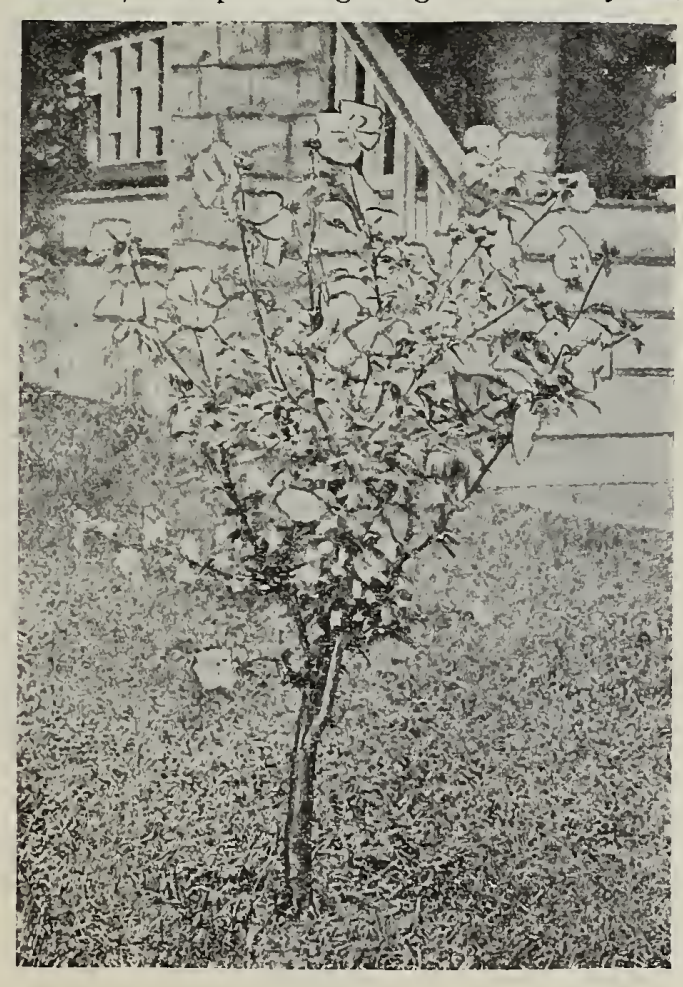

Althea and Honeysuckles nay be trimmed a very little during the Winter or early Spring, but it is a better rule to trinl all shrubs after they are through flowering. The Hydrangea Paniculata Grandiflora should be severely cut baci and trimmed early each Spring.

Almond. A beautiful, small shrub, blooming early in June; branches are literally covered with flowers of size and shape of daises; double white and double pink.

Althea, or Rose of Sharon. This beautiful shrub flowers late in Summer when most others are out of bloom. It bears large double flowers similar to Hollyhostes very abundaty on strong, erect branches. Very hardy and of easy cultivation. We have them in white, red, purple and striped; all double.

Althea, Variegated. Leaves bright green, broadly margined with a light yellow; very popular.

Barberry, Common European. A spiny shrub blooming in May and June with drooping racemes of yellow flowers followed by bright, orange-scarlet berries; much used for hedges.

Barberry. Same as above except in foliage, which is a rich violet-purple all Summer. Blossoms in May or June and bears bright colored fruit in Autumn. Also used for hedges.

Buffalo Berry. A native plant found growing in North and South Dakota. The flowers are small and yellow; the berries crimson-red; leaves downy white. Very fine for ornamental purposes.

Deutzia. A beautiful dwarf variety from Japan. It is covered with a profusion of white fowers in June: well adapted to planting in cemetery lot or small dooryards.

Deutzia, Pride of Rochester. A variety raised from Deutzia Creneta and froducinź large, couble white fowers; the 


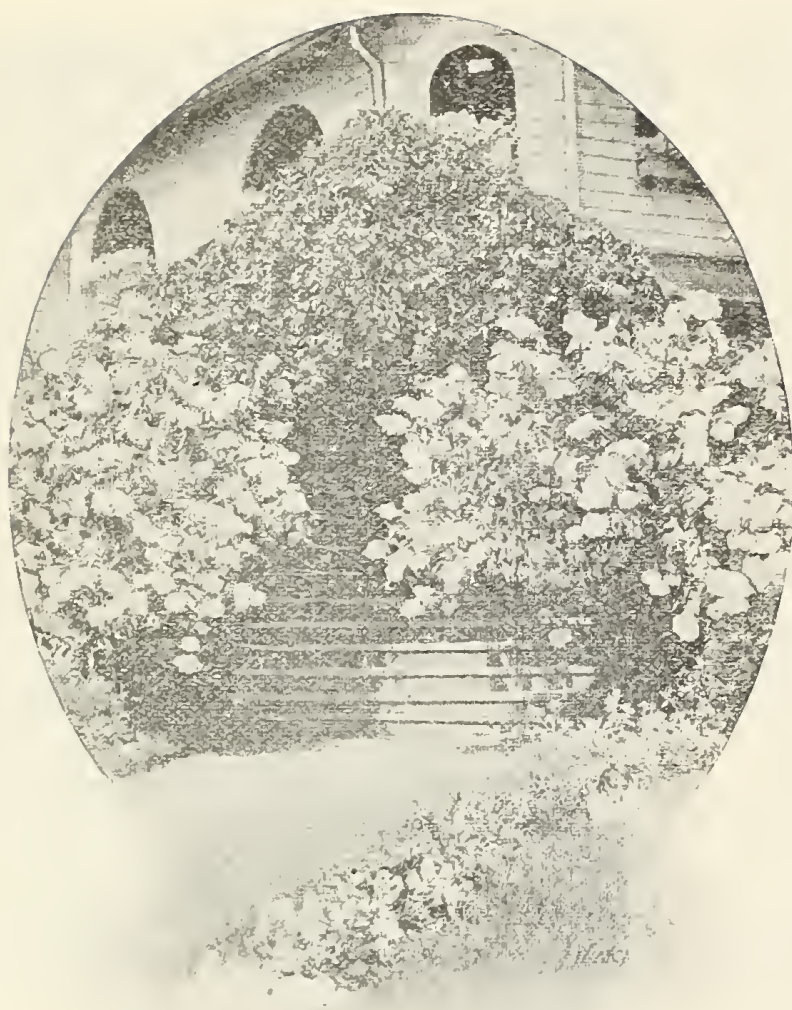

Hardy Hydrangea back of the pedats being tinged with rose. Flowers large, habit vigorous and a profuse bloomer.

Fringe Tree. In favorable locations, this develops into tree-like porportions; hardy in all localities. Blossoms in May and June. A very desirable shrub.

Golden Elder. From Holland. When the leaves Arst appear, they are bright green, but if planted where they will have plenty of sun, they soon change to a gol. den green. The blossom resembles the common Elder Bloom. One of the finest in cultivation, being especially effective in masses.

Honeysuckle, Tartarian. A strong, upright growing shrub; blossoms are pink and make a fine contrast to the dark green foliage. When planted in hedges and trimmed down, it makes a very beautiful appearance.

Honeysuckle, White Tartarian. A tall growing shrub with white flowers in May and June. Perfectly hardy.

(For Climbing Honeysuckle, see Hardy Climbers.)

Hydrangea, Paniculata Grandiflora. One of the best shrubs in cultivation. Is a strong grower and prow duces large panicles of white flowers in August that change to a delicate pink and then green, lasting till Winter; very showy and effective. It is often grown in tree form called Standard Hydrangea. See illustration on this page.

Lilac, Charles. A strong, vigorous grower with large shining leaves, large trusses, rather loose and red. ish purple.

Lilac, Common, Old.Fashioned. A familiar species with dense panicles of Lilac flowers. The most fragrant of all Lilacs. Extremely hardy.

Lilac, White. Similar to the Purple Lilac, but has pure white flowers. Very fragrant.

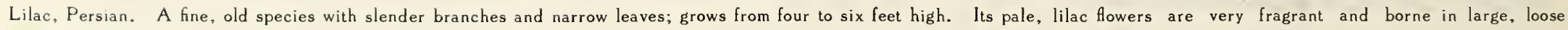
panicles. Very graceful. 
Snowball. A well known sort and a general favorite on account of its large clusters of white flowers. Very handsome and desirable and should be in every collection. Hardy in most lo. cations.

Snowball, Japanese. A rare and exceedingly beautiful species from Japan, surpassing the common Snowball in many

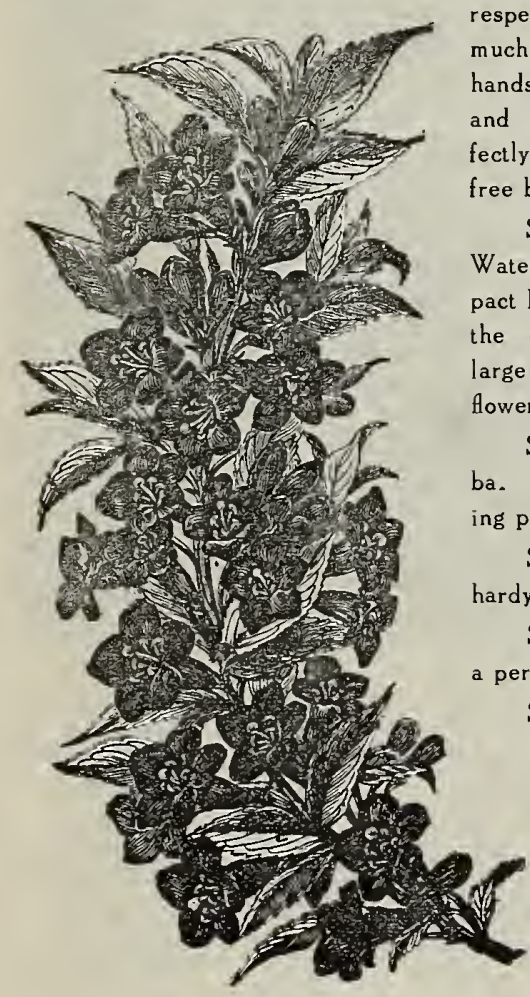

Weigelia

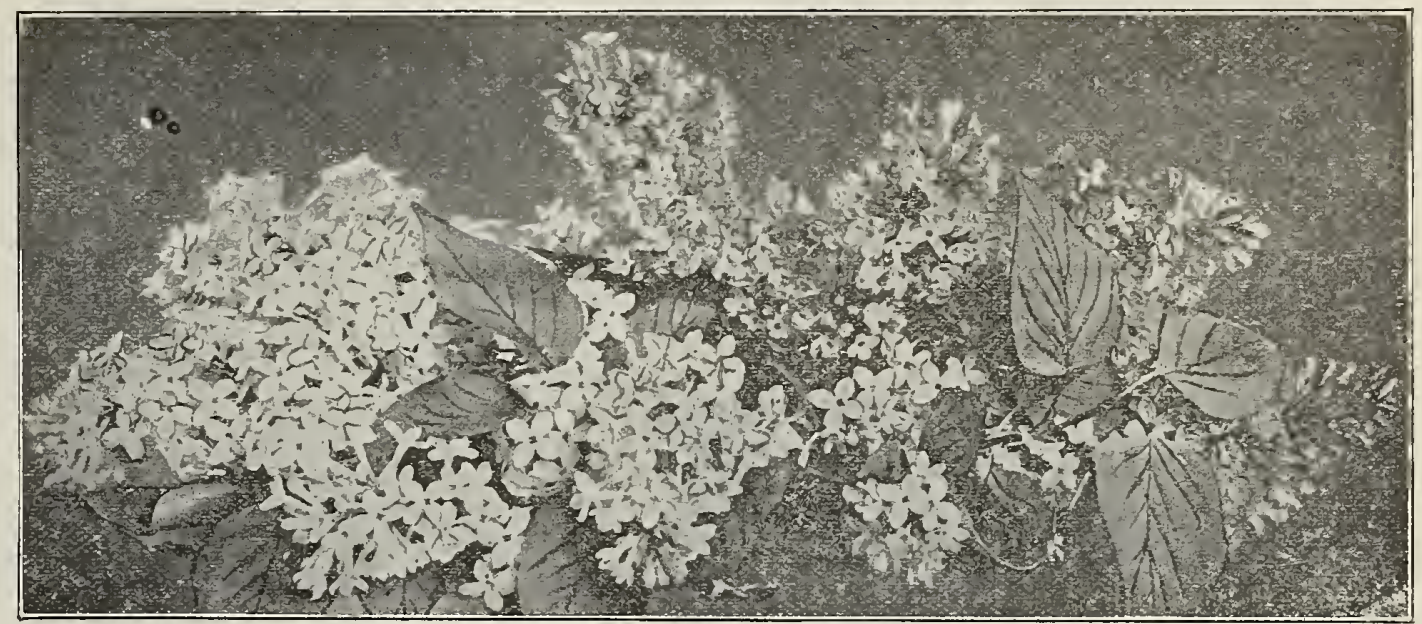

Old Fashioned Lilac

Spirea, Colossa Al-

ba. A dwarf variety hav.

g pure white flowers; blooms in great profusion. Very desirable on account of its dwarfish habits and free flowering qualities. Blooms in August.

Spirea, or Bridal Wreath. A beautiful shrub from Japan, having double daisy-like flowers of pure white in the greatest profusion. Very hardy and in every way desirable, as it keeps in flower a long time.

Spirea, Van Houtte. Without doubt the finest variety in the collection. A handsome ornament for the lawn in any season, but when in bloom, perfect fountain of white fowers. Perfectly hardy, blooming in May and June.

Syringa, or Mock Orange. Of vigorous habit, very hardy, with large, handsome foliage and beautiful white flowers. It merits a prominent place in all shrubbery collections.

Syringa, Garland. Well known, with pure white scented flowers, being one of the first to come into bloom.

Syringa, Golden. Strong, rapid grower; golden yellow foliage, well retained in color all summer. One of the best golden foliage shrubs.

Weigela, Hortensis Nivea. Flowers pure white, retaining their color and being clear enough for the choicest boquets. Foliage large, habit vigerous and a profuse bloomer; very distinct and desirable.

Weigela, Rosea. A hardy and beautiful shrub, bearing a profusion of rose-colored flowers: introduced from China and justly considered one of the finest shrubs we have. 
Weigela, Varigated Leaf. Very desirable on account of its finely variegated foliage which is yellowish-white and lasts the entire season, contrasting finely with its rose-colored flowers.

\section{HARDY CLIMBERS}

Ampelopsis Englemanni. Shorter jointed and having finer foliage than Quinquefolia. Clings to brick or stone; a good grower and hardy. Is considered the best for the North or Northwest.

Ampelopsis Quinquefolia (Virginia Creeper or American Ivy.) A native climber of vigorous growth with delicate leaves. A fine green in summer, changing to rich crimson in Autumn. It throws out tendrils at the joints by which it fastens to anything it toches; affords shade quickly and is very desirable for covering walls, verandas or trunks of trees.

Ampelopsis Veitchi. From Japan. Similar to the preceeding, having smaller or more lvy-like leaves. The leaves

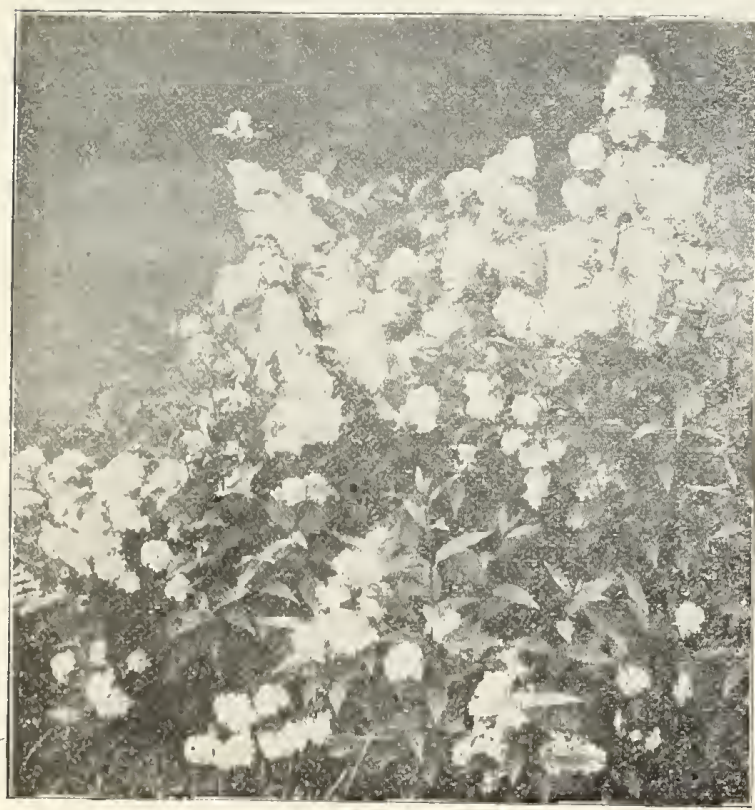

Syringa or Mock Orange overlap, forming a dense sheet of green. It clings lightly to even the smoothest surface and is unsurpassed. One of the fastest climbers. After becoming once established, is perfectly hardy and grows rapidly.

Clematis, Coccinea. A remarkably handsome climb. ing plant; one of the most desirable for any purpose where Climbing plants are required; the flowers are bell-shaped. One of the most beautiful plants for festooning with. Peculiar shaded green and elegantly cut and varied foliage. Bloom, Scarlet.

Clematis, Henryii. Of robust habit and a very fine bloomer. Flowers large, beautiful, creamy white, consisting generally of from six to eight spreading sepals; one of the finest white varieties.

Clematis, Jackmannii. This variety bears a profusion of large sized, intense violet-purple flowers, four inches across, richly veined and shaded with reddish-purple. It is a rapid grower, early and abundant bloomer, perfectly hardy and adapted to all kinds of culture.

Clematis, Paniculata. Of robust habit, climbing, pure white, deliciously fragrant, flowering foliage.

Clematis, Ramona. This magnificent Clematis is an American seedling and consequently extremely hardy. It is a perpetual bloomer, giving an abundance of fowers through the season. Skyblue.

Honeysuckle, Chinese Twining. A well known vine which lolds its foliage rearly all Winter; very sweet; nearly white.

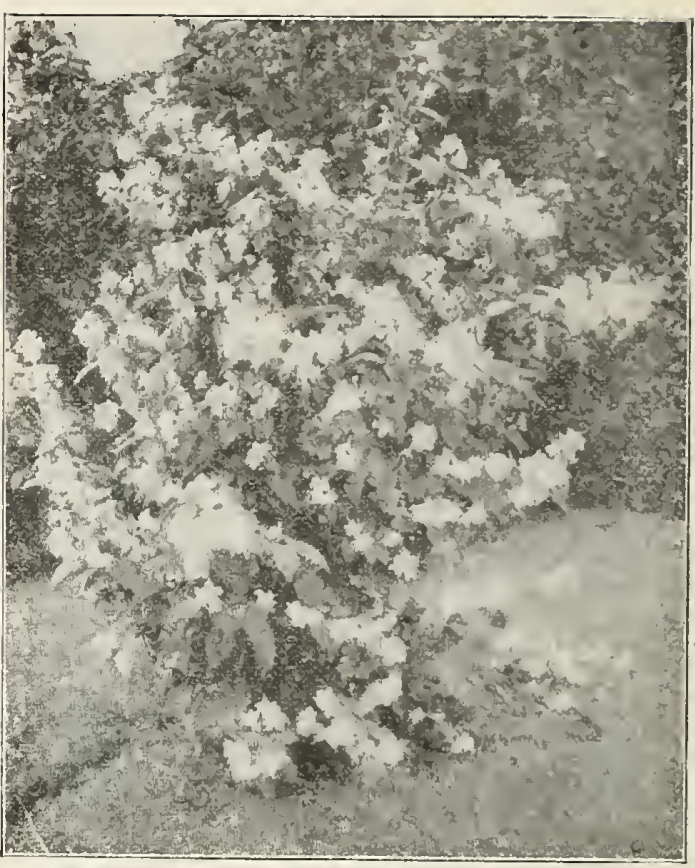

\section{Spirea or Bridal Wreath}

68 


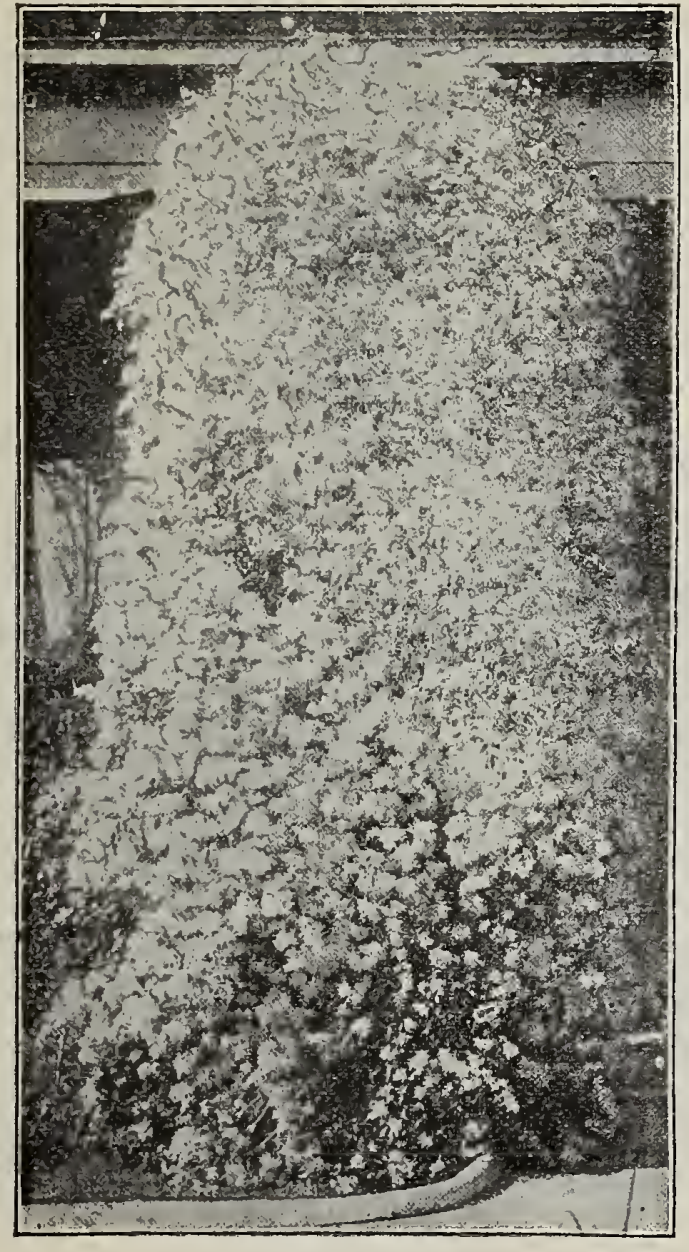

Clematis Paniculata
Honeysuckle, (Common Woodbine.) Very strong grower with showy flowers, red outside, buff within.

Honeysuckle, Scarlet Trumpet. Flowers deep red, trumpet-shaped and blooms all summer. A native Climber appropriate for trellises or rock work. This and its varieties are the handsomest in cultivation.

Matrimony Vine. A vigorous, hardy Climber covering a large amount of space; fowers bright purple succeeded by scarlet berries. Leaves turn to Crimson in Autumn.

Wisteria, Ch!nese Purple. One of the most magnificent hardy Climbers producing racemes of pale, purple flowers early in Spring and Autumn and growing at the rate of fifteen or twenty feet in a season, attaining an immense size.

Wisteria, Chiuese Whice. Differs from the above in color of flowers, which are pure white, forming a striking contrast and therefore is very desirable.

\section{HARDY ROSES}

Nothing that we can say will add to the popularity of the Rose, the most prized of all flowers. Those whose taste tend towards the beauties of nature cannot help classing the Rose at the head of ornamentals. Many make an effort to have an abundance of them in season, yet many fail because they plant inferior grown bushes which are sold so cheaply throughout the country that thousands buy them. Our Roses cost more than such stock, yet where they have been given a thorough test, they have yeilded far more for the money. Our bushes are ready to set in open air as soon as received, being hardy, vigorous, two-year old stock, all having bloomed once before sending out. Results depend largely on the care given them when transplanted, and if a little extra care is taken, it will bring large interest on the investment. Different varieties have different habits of growth the same as other plants. When stock is received, this must be taken into consideration. Some are tall and slender, others grow low and bushy, while some make a straggling, irregular growth.

Below we give an assortment of the best only, having been tested on our own grounds for years. The selection is sufficient for those wishing an extensive assortment and although there are hundreds of varieties, only a professional could distinguish any difference between those we list and other named sorts offered in many catalogues of nurserymen and seed men.

\section{HYBRID PERPETUAL ROSES}

American Beauty. Large, globular, pink shaded with carmine. Delicious odor. Not hardy in Minnesota or the Dakotas.

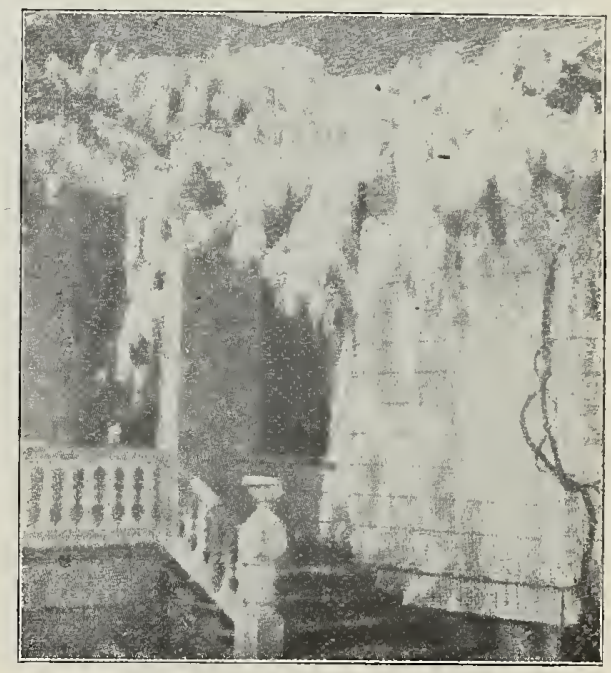

Wisteria, Chinese Purple 


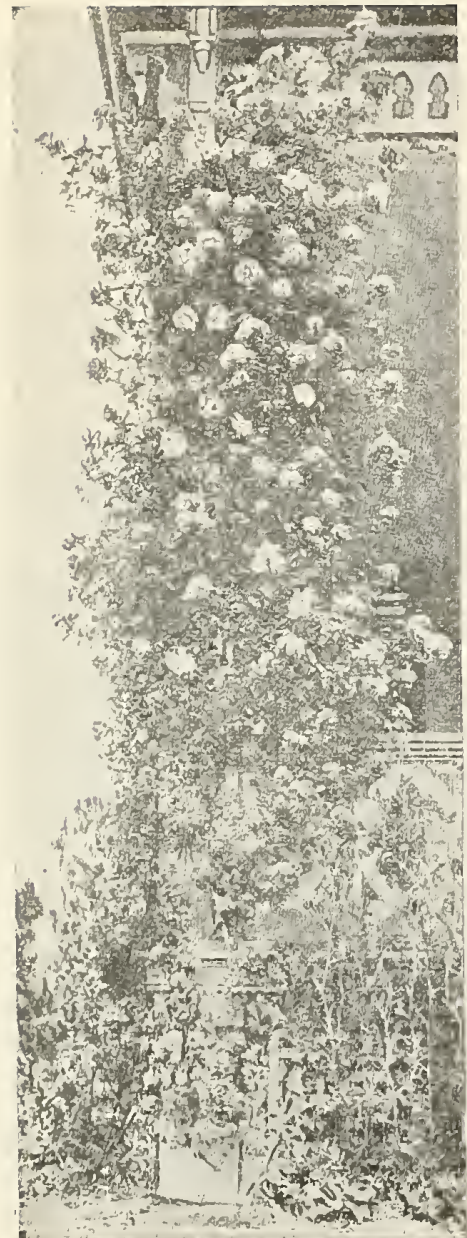

Crimson Rambler Rose

Anna de Diesbach. Carmine, a beautiful shade, very hardy, large and double, A fine garden sort.

Baron de Bonstetten. Large, deep, full of flowers of dark, crimson-maroon. A splendid, highly scented flower.

Baroness Rothschild. Light pink, cupped form. Very symmetrical, one of the finest exhibition varieties. The wood is short-jointed, very hardy and a late grower.

Black Prince. Deep, velvety crimson, large, moderately full. A splendid Rose and one of the darkest.

General Jacqueminot. Brilliant crimson-scarlet, very showy, free bloomer, fragrant, hardy, strong grower and very prolific.

General Washington. Brilliant rosy carmine, fine form and effective, Free bloomer.

John Hopper. Deep Rose with crimson center, large fine form and profuse bloomer.

La France. Delicate, silver-pink, large and very double; very fragrant and a constant bloomer.

Mabel Morrison. White, very full and double-cup shaped flowers; petals firm and erect. Very valuable.

Magna Charta. Bright pink, suffused with carmine; very large, full and of good form. Habit erect, magnificent foliage. Flowers produced in more than usual abundance.

Margaret Dickson. A very free grower, foliage large and dark, flowers white with pale flesh center; petals are thick and bell-shaped. Quite fragrant; a fine sort.

Marshall P. Wilder. Bright, cherry-red; of good size; very fragrant and perfectly double. Plant is a vigor. ous grower and continues long in bloom; one of the best of its color.

Mrs. John Laing. Soft, delicate pink. A free bloomer, vigorous grow. er; flower large, well formed and pro. duced on good stems. Fine in bud.

Paul Neyron. Deep red Rose, splendid foliage and habit, with larger flowers than any other variety. A free bloomer.

Ulrich Brunner. Flowers large and full, with exceedingly large, shell. shaped petals; color cherry-red. A splendid variety.

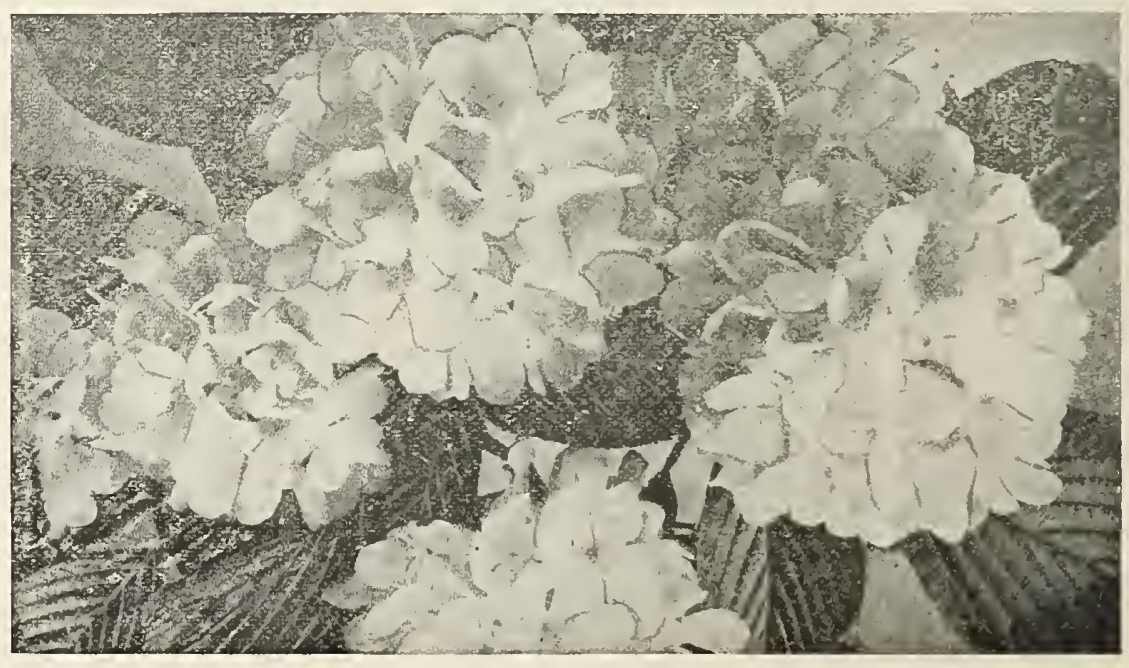

Japanese Snowball 


\section{HARDY CLIMBING ROSES}

Baltimore Belle. White, with bluish center, full and double; one of the most rapid in growth, with hardy and most luxur. iant foliage and immense clusters of flowers.

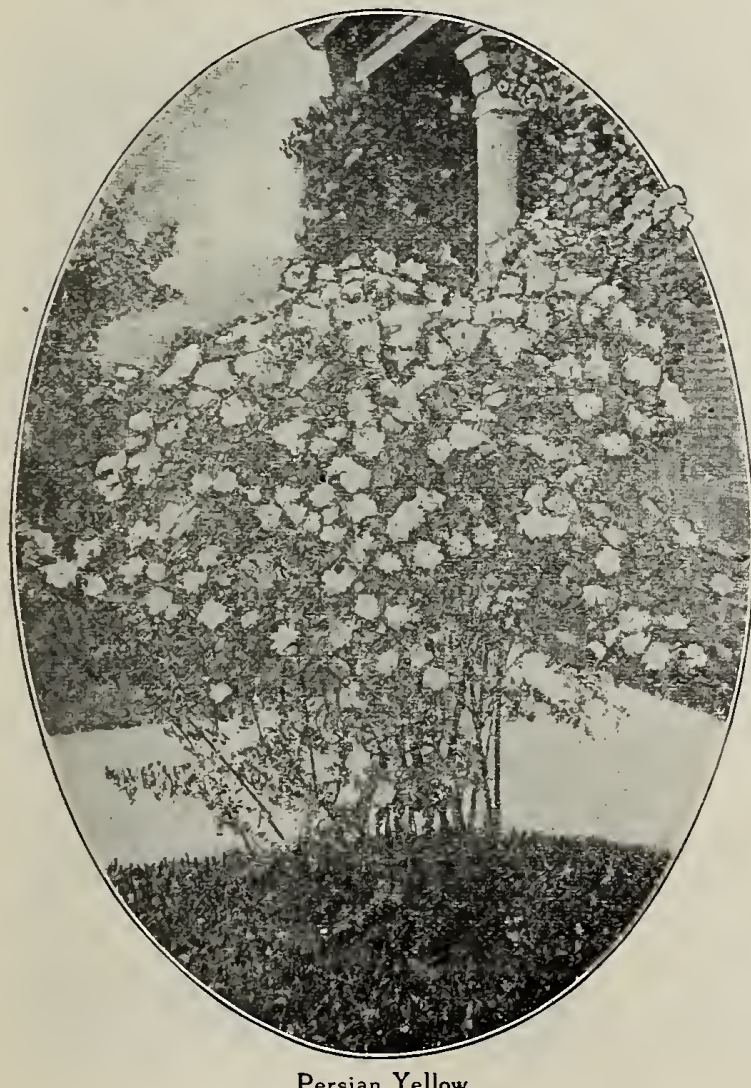

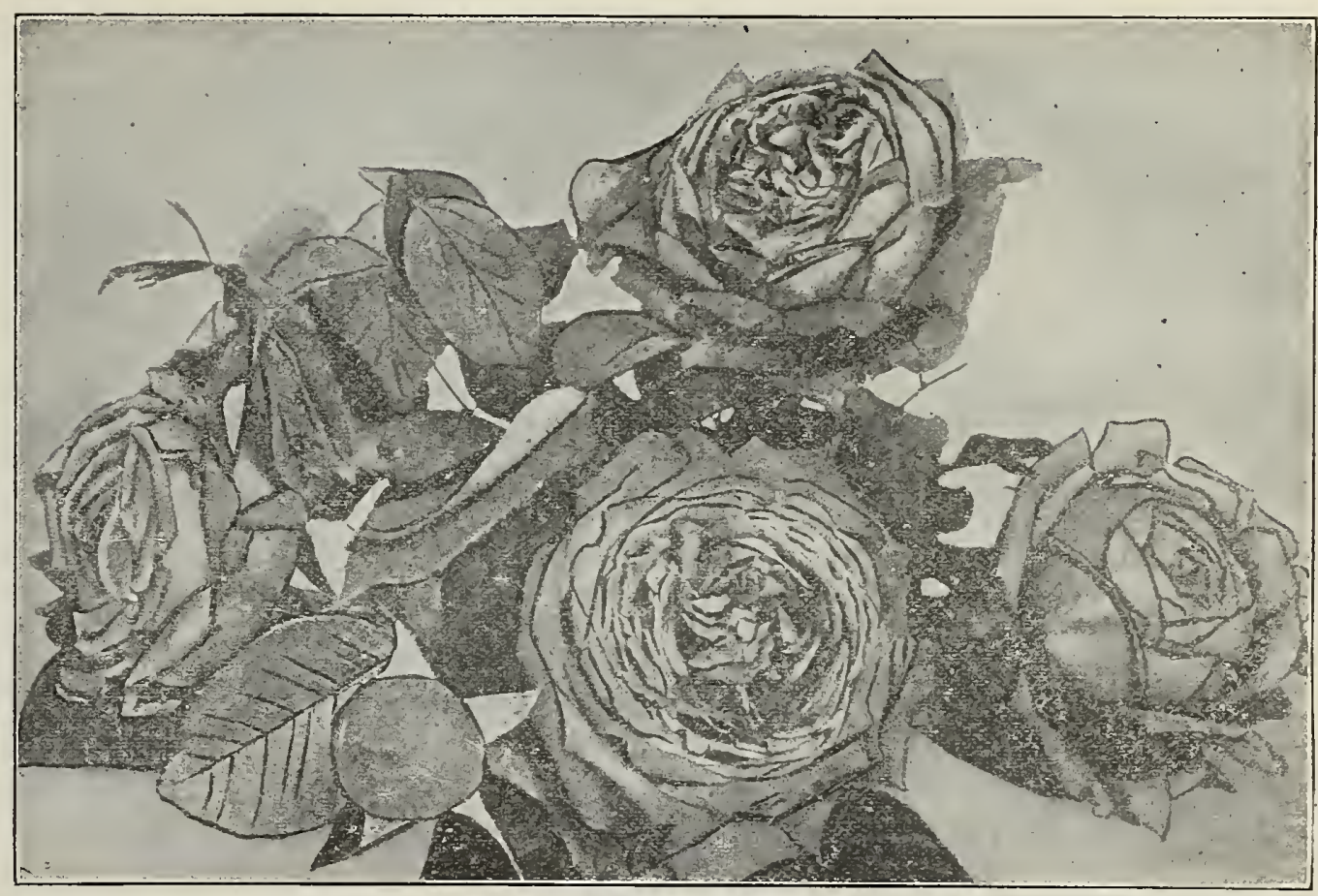

Baron de Bonstetten

Crimson Rambler The introduction of this sterling variety marks the greatest advance in climbing roses that we have had in the last quarter of a century. Perfectly hardy, wonderful free flowering, rich, glowing crimson, intensely bright and vivid in color. The plant is a strong, rampant grower, making shoots ten to twelve feet long in a season, after the first year or when well established. The flowers are produced in large trusses, pyramidal in shape, often twenty-five to thirty in a cluster, fairly covering the plant from the ground to the top with a mass of bright, glowing crimson.

Queen of the Prairie. Bright rose, sometimes striped with white, large and cupped, strong grower- 


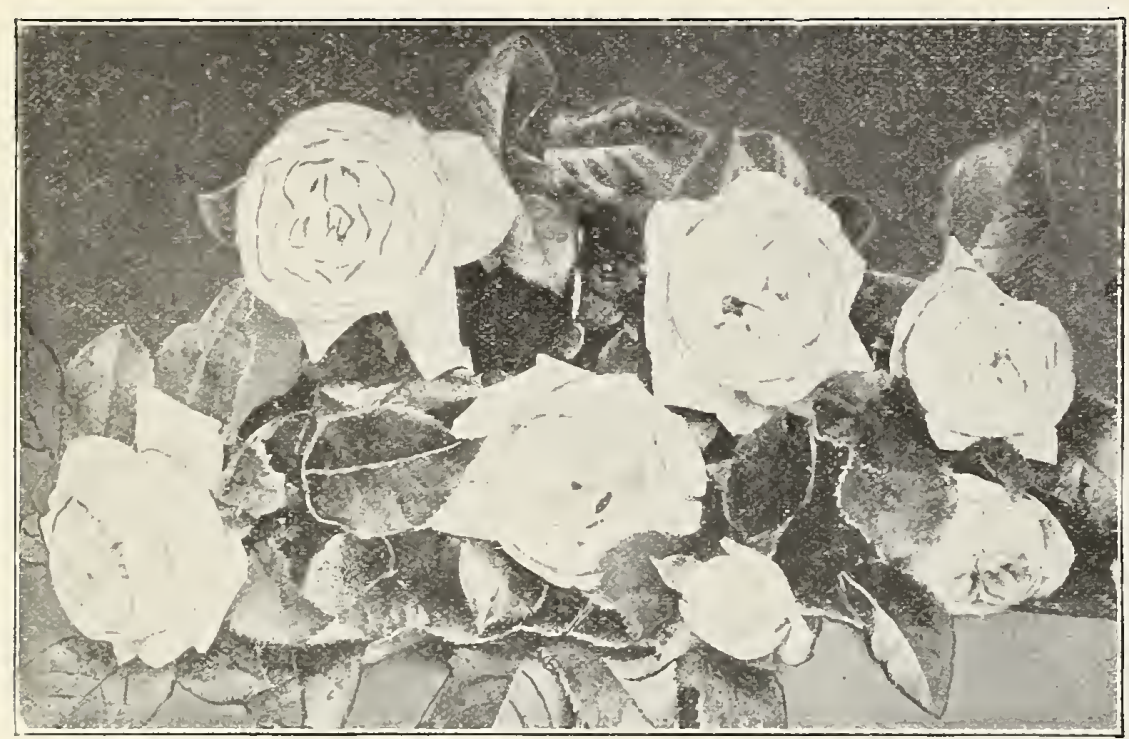

Margaret Dickson

Seven Sisters. A good variety, flowers borne in clusters, varying in color from whlte to crimson.

White Rambler. Identical with Grimson Rambler, different only in color, which is pure, clear white.

Yellow Rambler. A fit companion for Crimson Rambler, succeeding well in any lo. cality. Identical with Crimson Rambler, except !n color, which is pure yellow, lasting a long time without fading.

\section{MISCELLANEOUS} HARDY ROSES

Baby Rambler. This new Rose is a dwarf bush form of the Crimson Rambler and is an everbloomer. May be used as a pot plant or garden Rose, blooming continuously in either place. The blossom is of the same color and form as the Crimson Rambler, the clusters having from twenty to forty blossoms at a time.

Harrison's Yellow. Perfectly hardy; semi-double, blooms early.

Madam Plantier. Pure white double rose; plant of fine form and produces flowers in great abundance in June. Very good for cemetery planting,

Persian Yellow. Flowers double and full; deep, golden yellow. Blooms freely in June. F!nest hardy yellow rose grown.

Rosa Rugosa. A Japanese variety that forms a strong, sturdy bush four to five feet high. Foliage is dark, glossy green, imper. vious to the attacks of insects of all kinds; makes one of the best shrub hedges. The flowers are single. borne in clusters, followed by large, red seed balls. Very attractive.

\section{MOSS ROSES}

Henri Martin. Large globular flower, full and sweet; rich, glossy pink, tinged with crimson.

Luxumberg. Bright crimson, large and beautifully mossed.

Princess Adelaide. Fine red blush, large and vigorous.

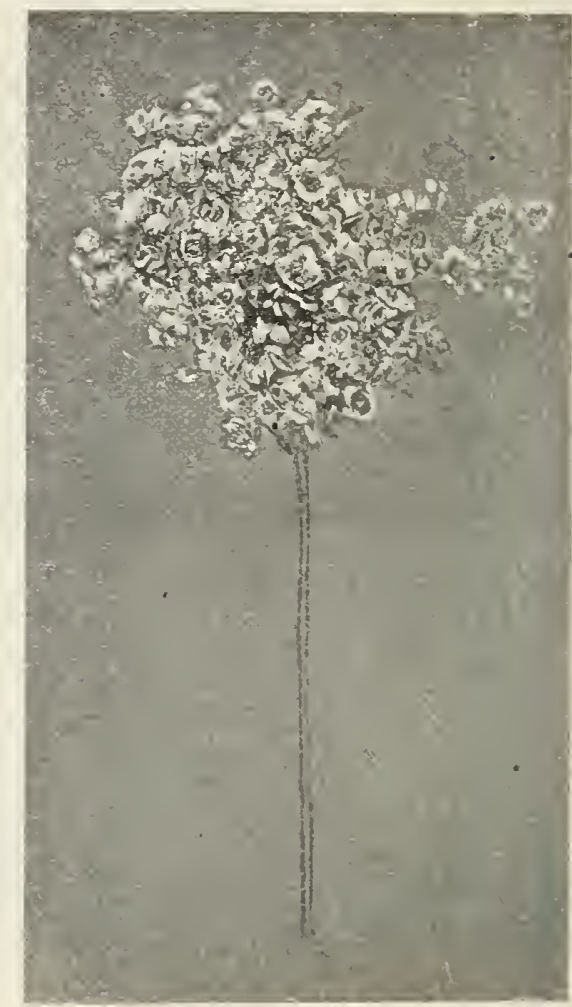

Tree Rose 


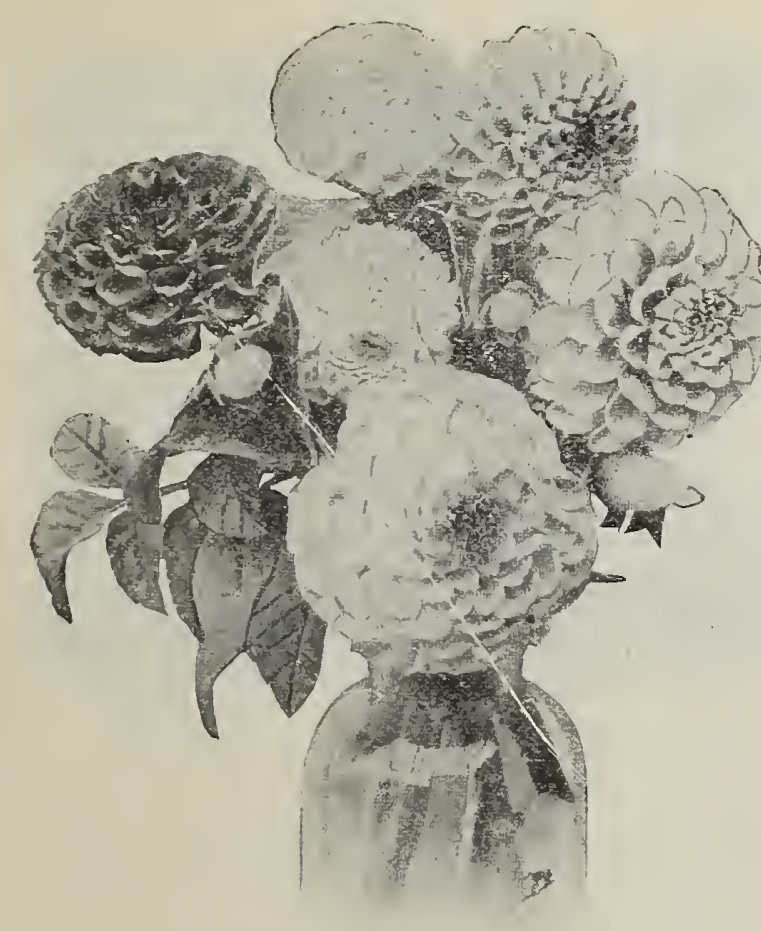

Dahlias

\section{TREE ROSES}

No handsomer ornament can be found for the lawn or the garden, however small, than the Tree Rose. Standing three feet or more high on its hardy stock, every individual bud and blossom can be seen and budded with hybrid per. petual roses, it is a beautiful object the season through. They seem to be exceptionally profuse bloomers, as many as 260 having been counted on a single bush. They are as easily cared for as other roses, requiring in fact, the same management. During the summer keep the ground well stirred, not allowing a weed to grow, as the sunlight is fully as needfull on the soil as on the foliage of the plants. If the season is dry, water once a week thoroughly at night and if possible shower them. They are easy to lay down and protect in the Winter.

\section{DAHLIAS}

In submitting our list of Dahlias, we want to call attention to the fact that we make a specialty of these plants. We grow our own tubers, start them in our own greenhouses and plant them in our own fields. By using this method, we can assure our customers that they wili receive an article superior to anything that is offered by others. We grow more Dahlias than any other firm in the Northwest and we certainly have a variety that is hard to beat. The bulbs must be taken up about the end of October each year when the leaves begin to wither, dried in the open air or stored in a dry place free from frost for planting the next Spring.

\section{CLASS 1-CACTUS DAHLIAS}

Matchless. A great variety, dwarf and branching, strong and vigorous. The flowers are large, rich glistening crimson, overlaid with dark velvety

maroon. An excelent variety and a profuse bloomer.

Miss Annie Jones. Bright crimson scarlet petals, narrow and much twisted, early and free.

The Queen. Pure snow white fowers of perfect shape, large size, with broad petals somewhat pointed. When given the proper attention, the best white for cutting.

CLASS 2-DECORATIVE DAHLIAS

Black Beauty. A grand, dark maroon variety of distinct form and great beauty.

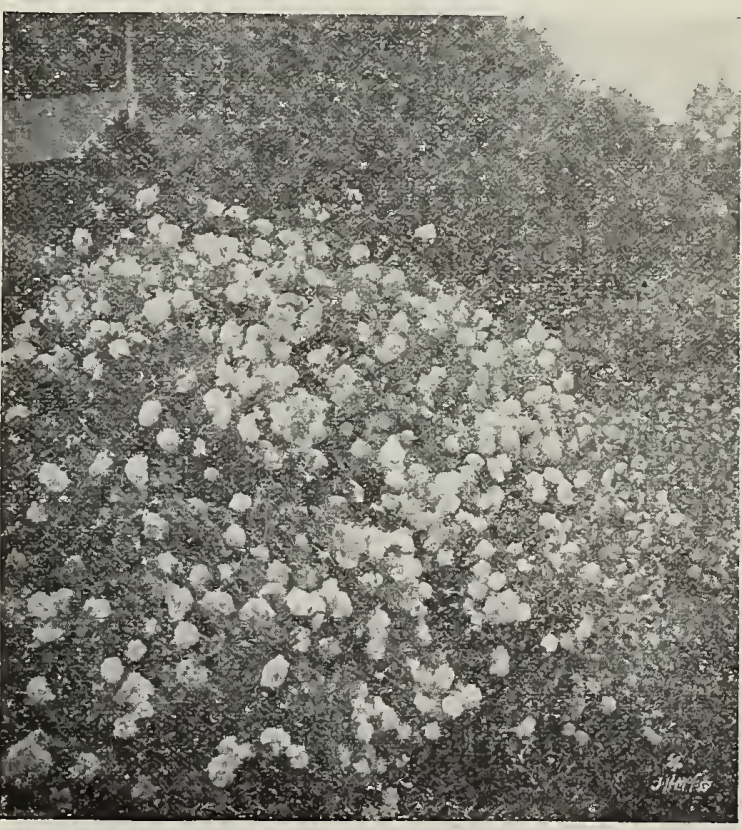

Madam Plantier 
Clifford W. Bruton. The best yellow, of immense size, perfect form and of the finest canary yellow.

Grand Duke Alexis. A magnificent flower of largest size and of distinct and unique form, as the petals are rolled up so that the edges overlap each other. Color is pure white, distinctly tinged with delicate pink.

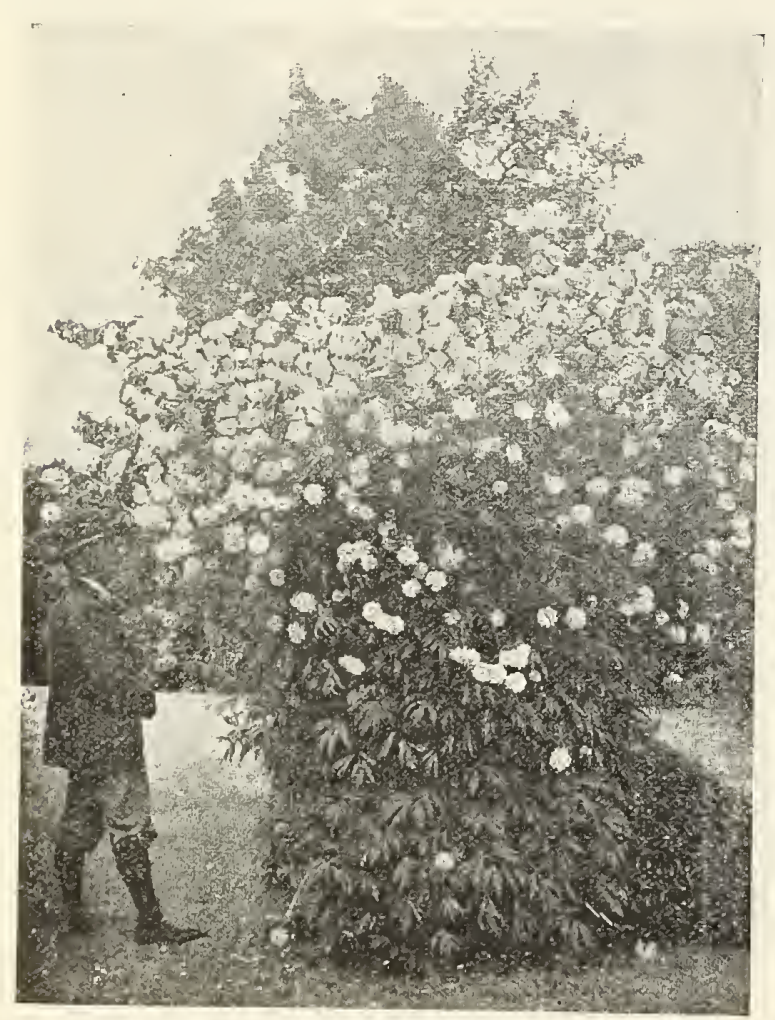

Colden Glow
Henry Patrick. A superb white variety large sized, borne on long stems and a fine variety for cutting.

CLASS 3 SHOW DAHLIAS

A. D. L'Voni, A beautiful, soft pink, with quilled petals full to the center.

Beauty. A snow white variety, of perfect form.

J. T. West. A

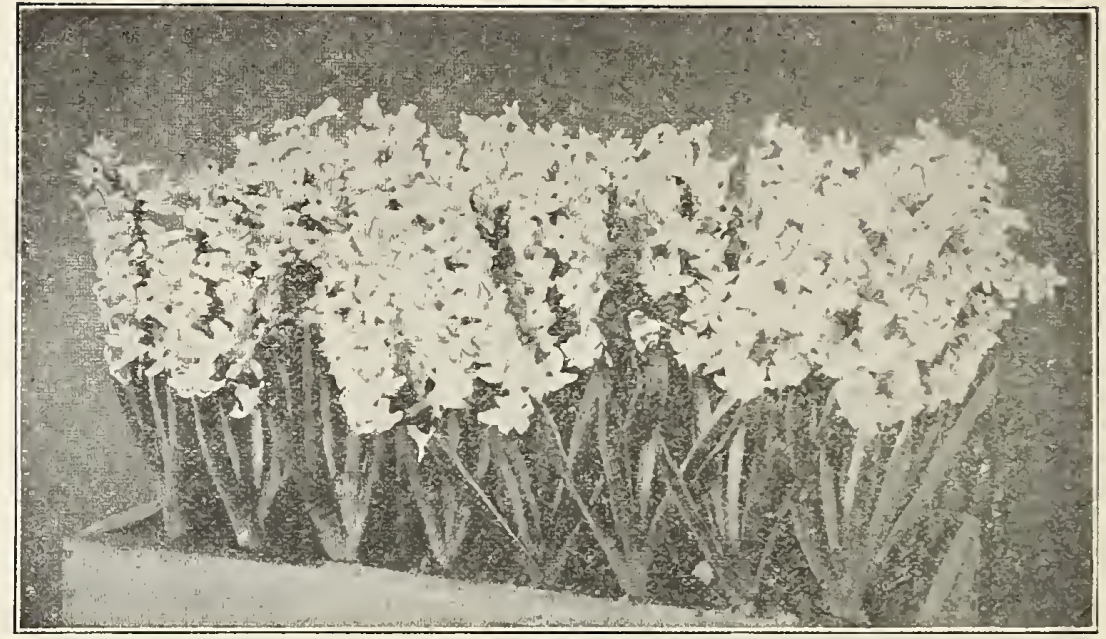

Hyacinths beautiful variety, white suffused with pink, tipped crimson maroon. A beautiful flower.

La France. Soft, rosy lavender, large, fine bloomer.

Magnificent. Pure, light yellow, very delicately edged with red. Flowers are regular, being perfect models in form. The plant is very dwarf and an immensely profuse bloomer. The best of all bedders.

Paul's Scarlet. The brightest scarlet.

Prince Bismark. Very fine and large, rich plum color.

Storm King, (or Blizzard). A companion for the superb pink Dahlia, A. D. L'Voni. This superior variety is an extremely early, profuse and healthy bloomer. The flowers are snow white, perfect in form and full to the center. Far ahead of any other White Show Dahlia.

\section{DUTCH HYACINTHS}

\section{(In Separate Colors)}

The Hyacinth easily takes the lead as being the most popular Winter flower in bulb. Its easy culture in pots, 


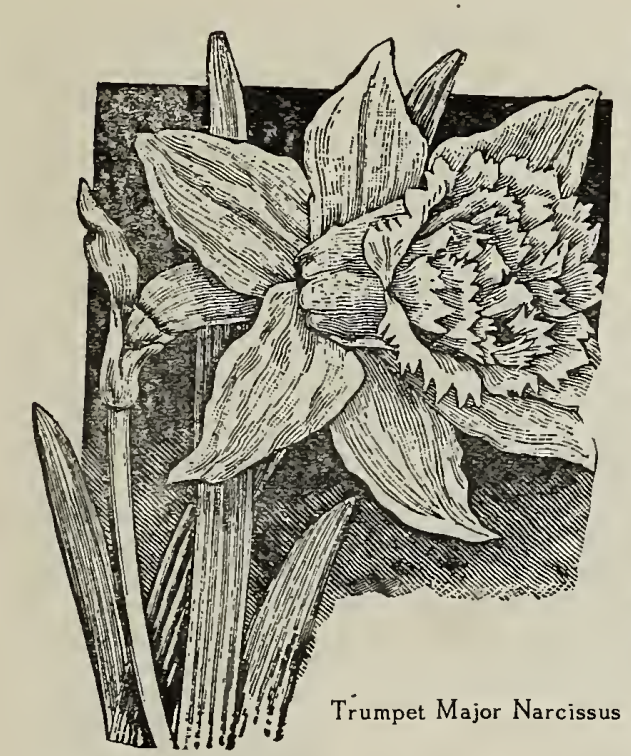

tinted rose, very fine. baker Scarlet. Scarlet. L'Immaculee. Pure white. Yellow Prince. Large golden yellow.

glasses or out door makes it a general favorite. The varieties offered have been selected for their beautiful colors, large spikes and fra. grance. Furnished in colors, blue, red, rose, white.

\section{TULIPS}

The Tulip is always attractive from its beauty and brilliancy of color, and is one of the popular early Spring flowers. A few bulbs scattered here and there produce but little effect, but when planted in masses or in small groups, they become at once grand and brilliant and eclipse in variety of coloring and picturesque effect almost any other flower. Our collection is unusually fine, embracing all of the choicest varieties. Tulips require cultural treatment similar to Hyacinths, but the bulbs being smaller, should not be planted too deep.

\section{DOUBLE TULIPS}

La Gandur. White. Murillio. Rose and white; very large and fine. Turnesoil. Scarlet, yellow edge. Yellow Rose. Bright yellow.
Cottage Maid. White, bordered pink. Kaiser Kron. Bright crimson, margined golden yellow. La Reine. Pure white
Pottebaker White. Pure white; one of the finest. Potte-

\section{PARROT-OR DRAGON TULIPS}

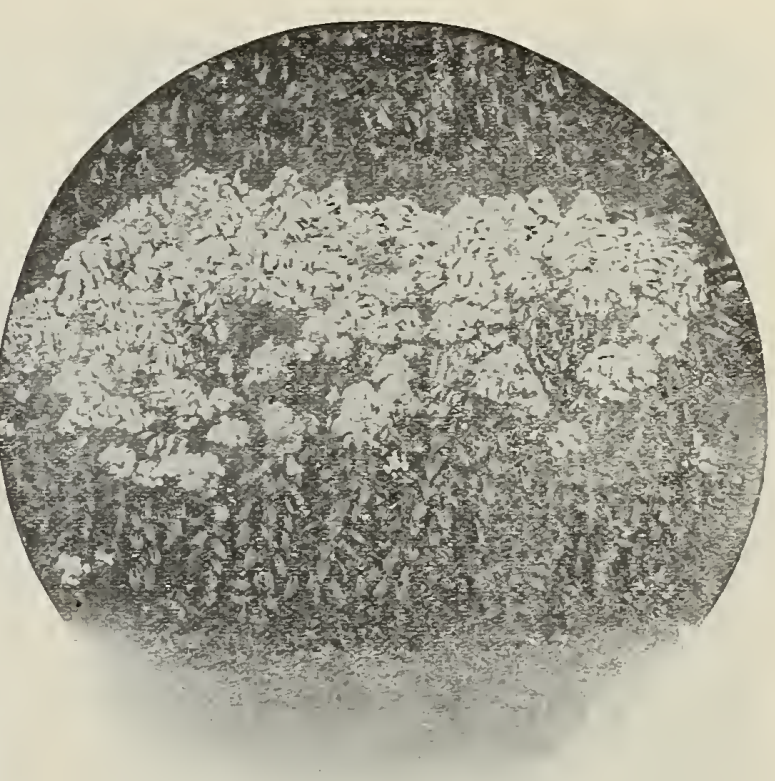

Hardy Phlox

Very large flowers of singular and picturesque forms and brilliant colors; very beautiful and interesting. The petals are curiously fringed or cut. They form extravagantly showy flower beds or borders, are of endless variety of form and color; stand a long time when cut and should be grown in every flower garden in quantity.

Constantinople. Orange scarlet with black markings. Gramoisie Brilliant. Brilliant carmine. Lutea. Clear yellow, feathered with red and green. Margraaf. Yellow Alamed with scarlet. Perfecta. Striped yellow and red.

GLADIOLUS: The Bride. A lovely, pure white form of the Gladiolus Colvilli. The flowers are freely borne on long stems. The bulbs are equally as good for indoor or outdoor

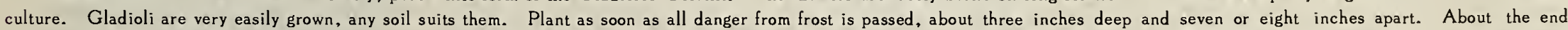

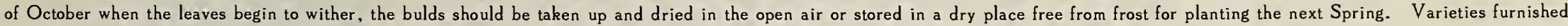
in all shades and colors. 


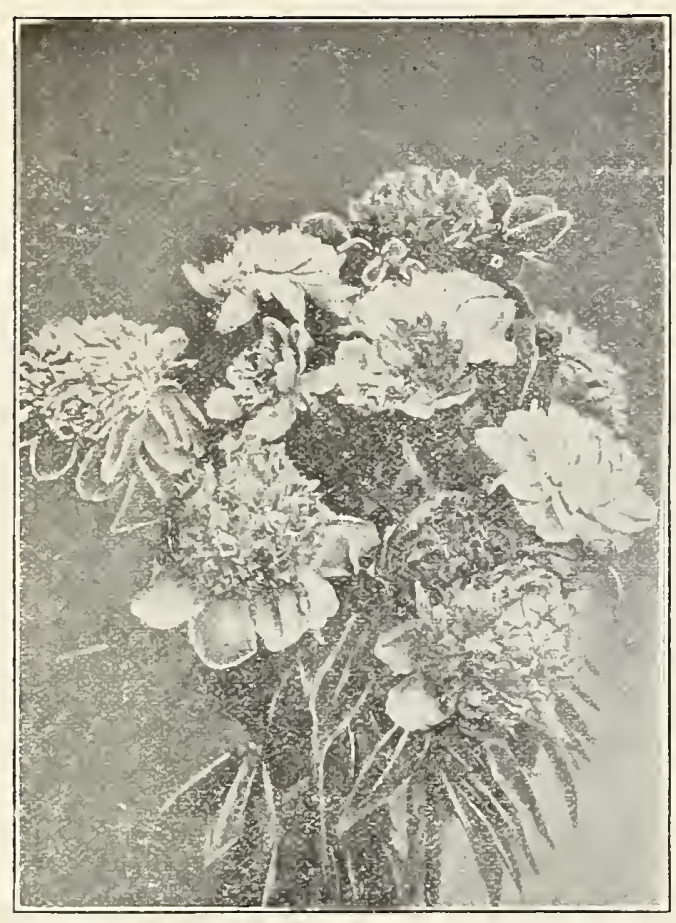

Herbaceous Paeonies

\section{HARDY PERENNIAL PLANTS}

We offer a list of varieties which years of experience have proven successful. Our stock is large and exceedingly wel! grown.

ACHILLEA (The Pearl). Pure white; flowers all summer.

GOLDEN GLOW A distinct, tall-growing, hardy perennial, foliage bright green; flowers rich yellow, borne on long, smooth stems, forming for the tall plant a solid head of bloom. Excellent for cutting.

JONQUILS. All the Jonquils are prized for their graceful, golden, fragrant blossoms and the ease with which they may be grown. Haif a dozen can be placed in a five inch pot and grown the same as Hyacinths and a fine display can be had from January to April.

NARCISSUS, or DAFODILS. There are no hardy bulbous plants which have more points of merit than the Narcissus. Perfectly hardy, growing and doing weli in almost any and every position, sun or shade, moist or dry. They are equally desirable for pot culture for Winter flowering; but it is outdoors that Narcissus do best. and once planted, need no further attention. Golden Spur,(Large Trumpet Varieties). Large, spreading, full deep yeliow perianth; trumpet golden yellow. The best of the Golden Trumpet. Trumdet Major,(Single varieties). A large and shapely flower of rich color throughout. Excellent for bedding purposes. Von Sion, (Double Daffodils). A famous old Dutch Daffodil, flowers golden yellow, large and of fine form. Excellent for bedding in conjunction with Hyacinths, flowering at the same time.

PHLOX. Probably the msst important and best known of the hardy perinneal plants. They flower continuously from early Summer until late in the Fall and embrace a larger range of color than can be found in any other species. We have to offer a collection of the best and most distinct varieties.

\section{PAEONIES}

The development and increase in popularity of the Paeony has been unparalleled among flowers. The public has been quick to notice the improvements and appreciate them until now no ffower is more popular in June. Paeonies range in coior from purest shades of white through the various shades of pink, rose and red to the deepest blood and purplish carmine, in every combination of shade, form and size. Many are delightfully fragrant. Paeonies like most tuberous plants, when dormant, stand considerable exposure and can be shipped lon distances with safety. They require no covering during the most severe weather. In fact they are among the most hardy, showy and easily grown of all garden flowers. Varieties listed below are the ones we consider best.

Festiva. A good white, much like Festiva Maxima, but shorter. Festiva Maxima. Delicate Paper white, with carmine flaked tip to a few center petals. A strong grower with immense flowers. Early, free and very fragrant; from four to eight flowers on a single stem. Humea Alba. Soft lilac at first, changing to uhite. No markings. Dwarf and very late. with long pointed buds.

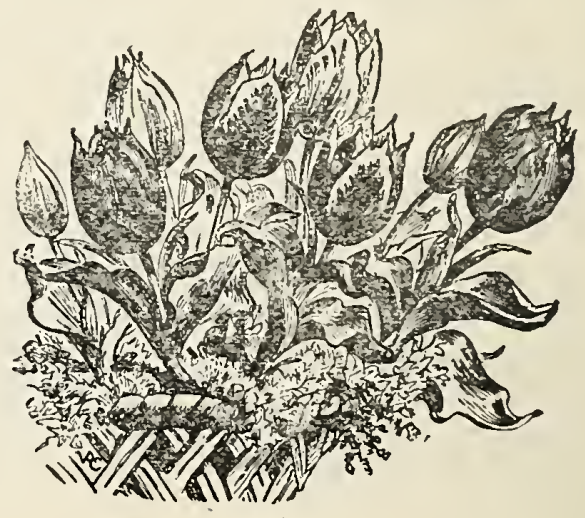

Tulips 
Mont Blanc. Fine, large, early, fragrant, with lemon center. Queen Victoria. A full, strong white with yellowish tinted center.

PINKS. Alexander Dumas. Variegated rose and ecru. Very full and a vigorous grower; fragrant and one of the best early pinks. Baroness Schroeder. Flesh pink, very wide guard petals, a circle of many sized petals. Clarissa. Old standby. Delicatissima. A large flower of very delicate, clear pink, lighter in center, very fargrant. Dorton Coros. A good, pleasing variety. Dr. Andre. Very double, rose shade, dark pink of solid color. Officinalis Rosea. Bright, rosy pink. Virginie. Very large, delicate flesh pink, carmine tipped petals in the center. Petals thin.

ROSE. Charles Verdier. Lilac carmine, very strong fragrance. Duc Decazea. Large guard of rich car. mine: center pink, shading to salmon. Several blooms on a stem. Gen Lawton. Bright rosy pink which changes to nearly white. A few stamens in the center. Very large flower and delicate fragrance. Mad. Louise Mere. Rosy purple, silver reflectors, large and fine. Rosea Superba. Fine, full, rosy, extra choice flower.

RED. Augustine D'Hour. Cardinal red, narrow center petals, large bomb shaped and free bloomer. Comte de Diesbach. Purplish, crimson, fragrant. Meissonier. A mid-season variety with yellow stamens and of the deepest dye. Purpurea Delachei. Very deep amaranth purple, fragrant and a free bloomer; a very desir. able variety. Richardson's Rubra Superba. Very late, dark crimson; very fine. The best late black without any stamens. Victoire Modeste. Silvery rosy guard petals with white center.

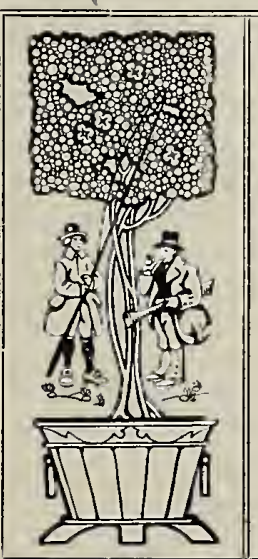

\section{SEND FOR OUR}

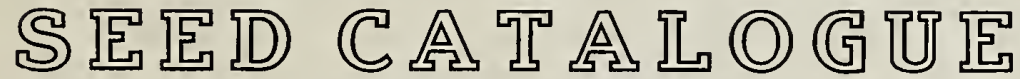

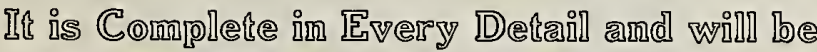
MLaîled Frees urpon Request

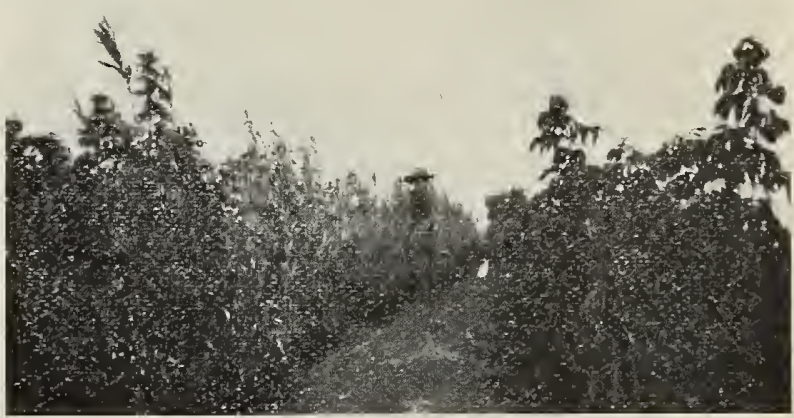

The above Halftone shows one of the many fine groves sold by us to progressive farmers of the Dakotas. The testimonial printed below fully explains the customer's version of the investment.

\begin{tabular}{|} 
ONE OF MANY TESTIMONiALS \\
Newville, N. D., Sept. 22, 08 \\
Clinton Falls Nursery Co. \\
Owatonna, Minnesota \\
Gentlemen-Enclosed I send you a photo of my Golden \\
Willow and Box Elder grove, planted in the Spring of $1906 . \quad$ I \\
also have one thousand Norway Poplars which have made a fine \\
growth, they being planted this year. I prize them very highly. \\
Yours Truly, \\
D. A. Hufford
\end{tabular}




\section{¿oose Curth rilowers}

FOR ANY OCCASION

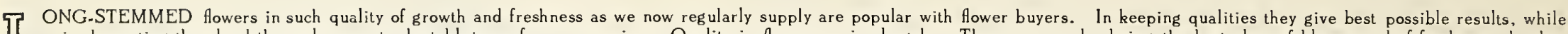

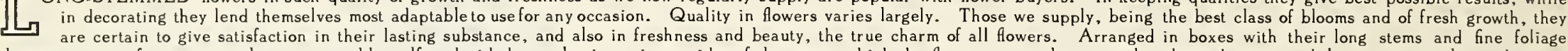

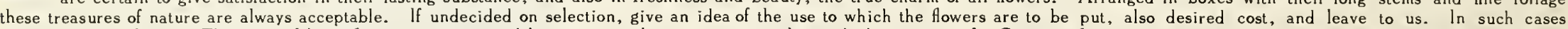

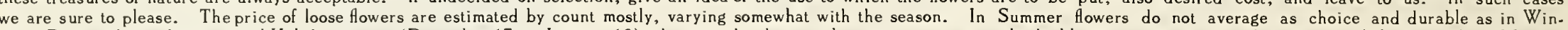

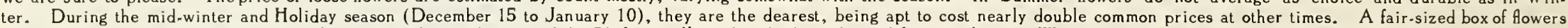

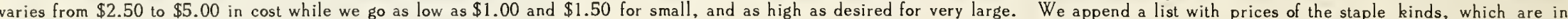
daily supply at our Greenhouses in their respective seasons.

\section{PER DOZEN PRICES ARE GIVEN EXCEPT WHERE NOTED}

ROSES-Pink Sorts as Bridesmaid and Chatney

Red Sorts, as Meteor, Liberty and Richmond

White Sorts, as Bride, Kaiserine, etc.

Assorted Kinds, our choice in special quality

Above class in good reliable quality

CARNATIONS-White, Red, Pink, etc., extr

Above class in good reliable grades
Fancy kinds, usually of extra quality
Nov. to April (Except

Holidays) also Easter

$\$ 1.50$ to $\$ 3.00$

1.50 to 3.00

1.50 to 3.00

2.00 to 3.00

1.00 to 2.00

.75 to 1.00

.50 to 1.00

1.00 to 1.50
Holidays

Dec. 15 to Jan. 10

$\$ 3.00$ to $\$ 5.00$

3.00 to 5.00

3.00 to 5.00

3.00 to 5.00

2.00 to 4.00

1.00 to 2.00

.75 to 1.00

1.50 to 2.50
April to October

Inclusive, Except Easter $\$ 1.00 \$ 1.50$ and $\$ 2.00$

$1.00 \quad 1.75$ and 2.50

$1.50 \quad 1.75$ and 2.50

$1.00 \quad 1.50$ and 2.00

.75 to 1.00

.50 to .75

.60 to 1.00

LILIES-Easter kinds Callas, December to May inclusive, each $25 \mathrm{c}$; per dozen, $\$ 2.50$ to $\$ 3.00$

GHRYSANTHEMUMS-October, November and December; selected $\$ 1.00$ to $\$ 5.00$ per dozen; specimen flowers, $25 \mathrm{c}$ to $50 \mathrm{c}$ each

NOTE_-"Easter" refers to a seven day period, beginning with the Wednesday before Easter.

Tulips and Hyacinths. February and May inclusive. Assorted colors, $75 \mathrm{c}$ to $\$ 1.00$ per dozen Daflodils and Narcissus. White and Yellow, February to May, $75 \mathrm{c}$ to $\$ 1.00$ per dozen

Lily of the Valley Sprays. $75 c$ to $\$ 1.00$ per dozen
Roman Hyacinths. White. November to January, 75 c to $\$ 1.00$ per dozen

Maldenhair. 50c per dozen

Smllax Strings. Four to six feet long, each $25 \mathrm{c}$ to $35 \mathrm{c}$

A sparagus. Sprays, $25 \mathrm{c}$ per dozen: Strings at $50 \mathrm{c}$ each

Asparagus. Sprays, $25 \mathrm{c}$ per dozen; Strings at
Easter LIIIles. $20 \mathrm{c}$ to $25 \mathrm{c}$ per bud or bloom.

LEADING KINDS OF FLOWERS THAT ARE IN OCCASIONAL SUPPLY-PRICES ON APPLICATION

November and December. Bouvardias and Stevias, Freezias and White Narcissus

June. Hardy Roses and Paeonies from outdoor

August. Gladioli, Tuberroses, Hydrangeas

July. Sweet Peas, Asters, Stocks

September and October. Gladioli, Asters', Hydrangeas, Dahlias, Cosmos

Extra selected blooms of going kinds, and of new or choice varities can oftimes be supplied. Apply specially for kinds of stock and prices 


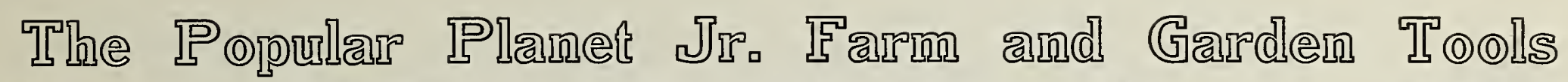

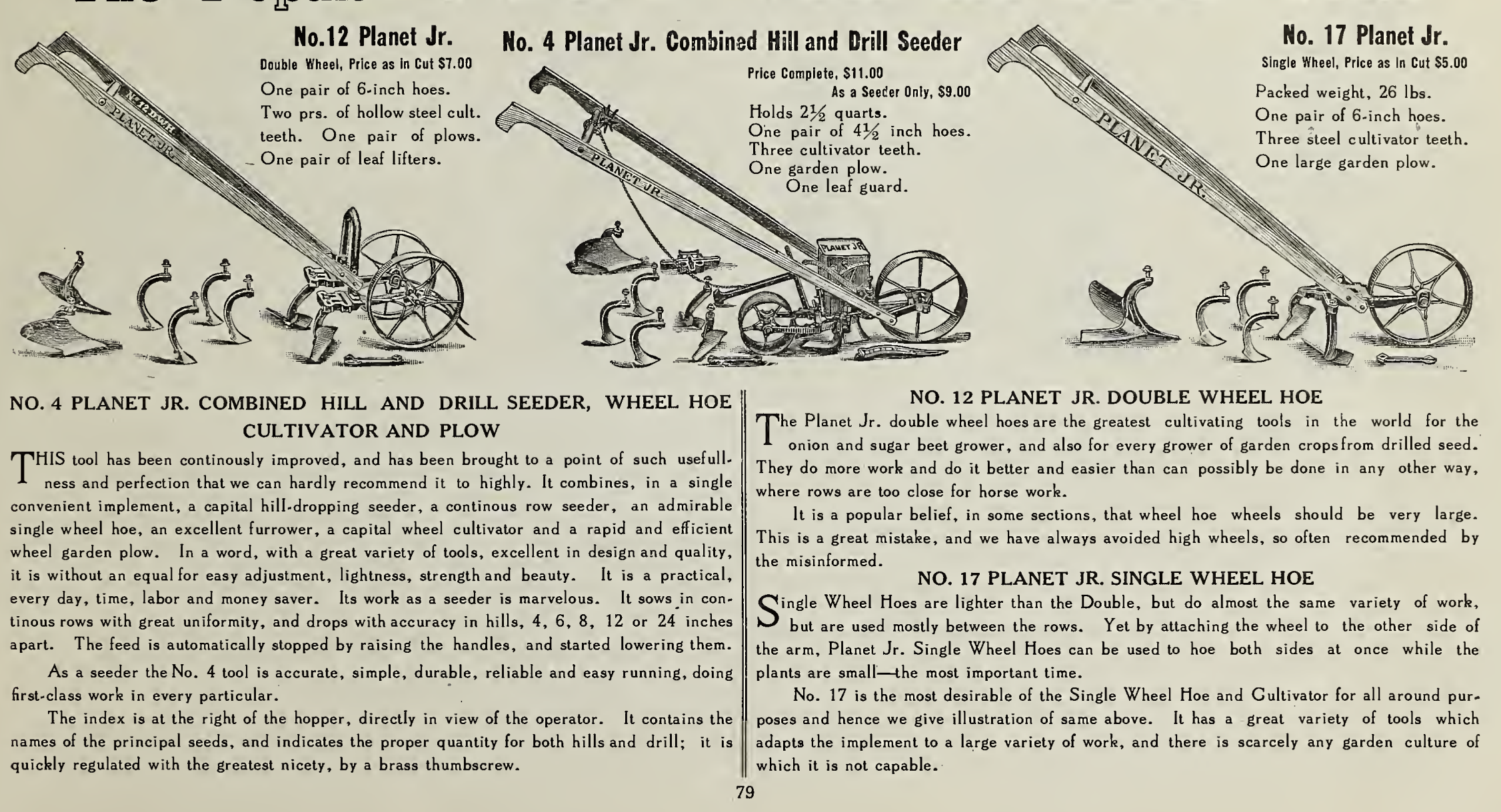




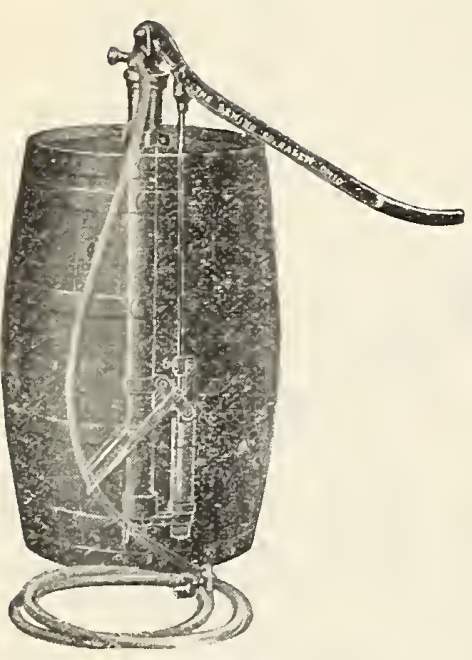

No. 645

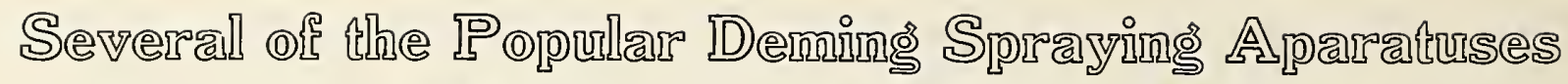

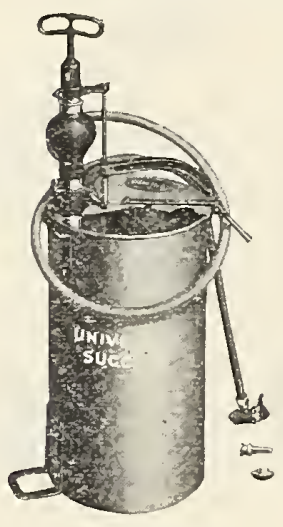

No. 662

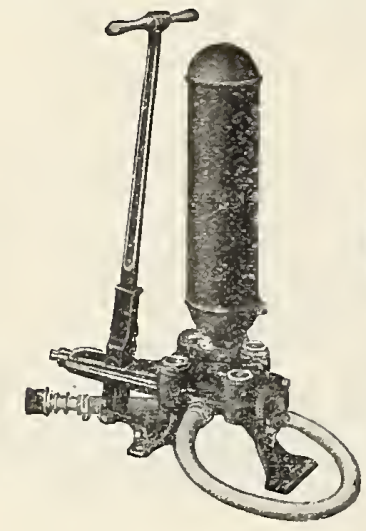

No. 614

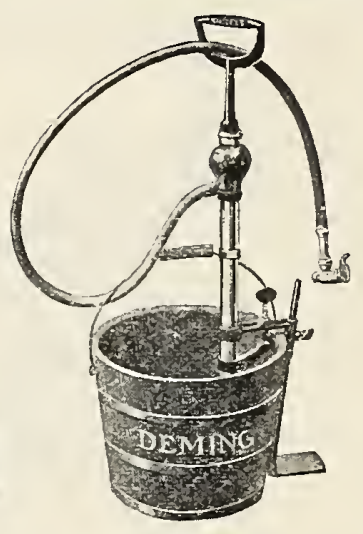

No. 689

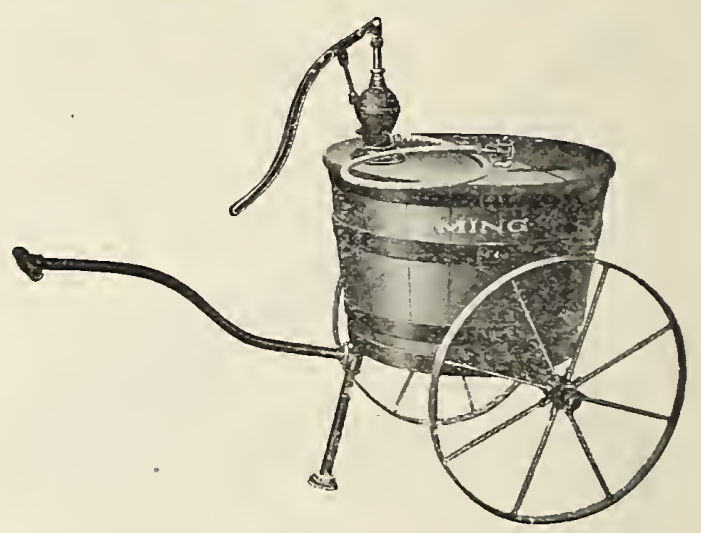

No. 651

The "Century" Barrel Sprayer, No. 645. The "Century" stands in the front rank of barrel sprayers. It has brass working parts throughout. The large air chamber is located within the barrel; hence there is no projection to catch on low branches. The cylinder is submerged in the liquid and is constantly primed.

The agitator is operated by the lever. An iron base is furnished, in which is a filling hole with cap. When specified, we furnish a curved base for the side of the barrel. If this be desired instead of a flat base, so state in your letter.

The "Gentury" is'made in two sizes: No. 1, $13 / 4$ inch, and No. 2, $21_{4}^{1}$ inch cylinder. No. 645, Sprayer only, with $Y$ connection

No. $1 \$ 11.50$ No. $2 \$ 13.50$ Outfit $A$, as above, $12 \mathrm{ft} 1 / 2$ in hose nozzle and pole holder... No. $1 \$ 16.00$ No. $2 \$ 18.00$

The "Success" No. 662. Useful for washing poultry houses and stables; also for disinfecting, spraying, etc. The tank is galvanized iron and holds five gallons. A strainer and agitator are provided, also a cover to prevent liquid splashing out.

No. 662 as illustrated $\quad \ldots . . \$ 9.00 \quad 7 \mathrm{ft} \mathrm{sec}$ hose, coupling, pole holder $\$ 2.00$

The "Gardener's Choice," No. 651. This outfit meets the needs of the florist, growers of small fruits, etc. The frame is largely wrought-iron pipe, and the twenty-four gal.

lon tank is hardwood, well hooped. These features, together with the wrought-iron wheels, make the outfit strong and durable.

The pump has $1 \frac{1}{2}$ inch brass cylinder and 4 inch stroke, and is furnished with four feet of hose and "Bordeaux" nozzle.

No. 651, as illustrated

$\$ 15.007 \mathrm{ft} \mathrm{sec}$. hose, couplings, pole holder $\$ 2.00$

The "Bonanza" Hand Sprayer, No. 614. Persons desiring a pump of greater capacity than a barrel outfit will find the "Bonanza" especially adapted to their work. It is powerful and is easily operated, considering its size. It is fitted for attaching one to four leads of hose. The large air chamber assures uniform pressure; all working parts are brass; valves are readily accessible.

No. 1,2 in cylinder $3 \frac{1}{2}$ in stroke $\$ 27.50$ No. $2,2 \frac{1}{2}$ in cylinder $4 \frac{1}{2}$ in stroke $\$ 32.50$

Deming Bucket Sprayer, No. 689. These Bucket Sprayers have been recognized for years as standard. Their constantly increasing sale stands as a testimonial of their worth. Four feet of hose and "Bordeaux" nozzle furnished.

No. 689, as illustrated. .......... \$5.00 $7 \mathrm{ft}$ sec hose, couplings, pole holder $\$ 2.00$ Write for prices of attachments and other information. 


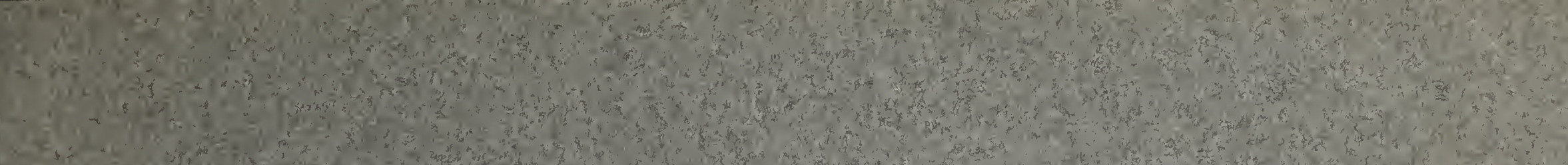

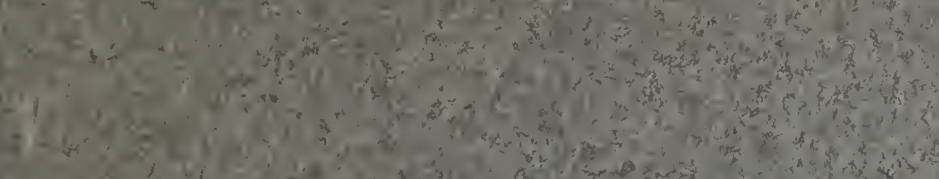

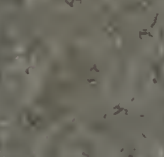
$(-3)=3(i)$

$\cdots$

in $\operatorname{lin}_{i}$

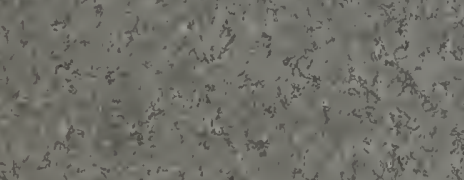

and

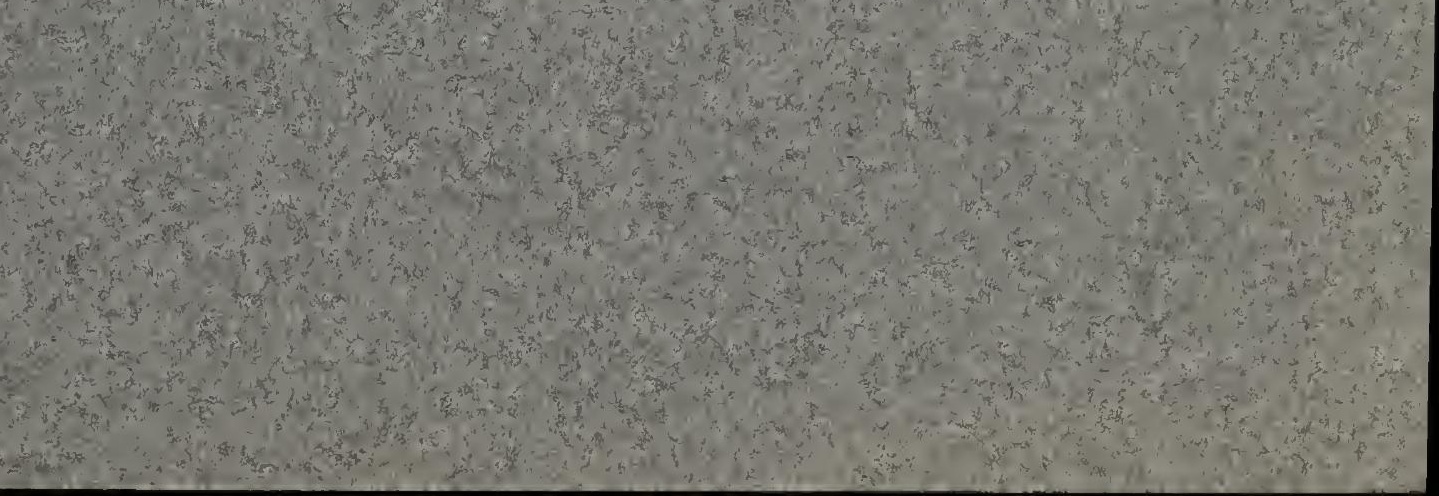


$\frac{1}{4}$

and

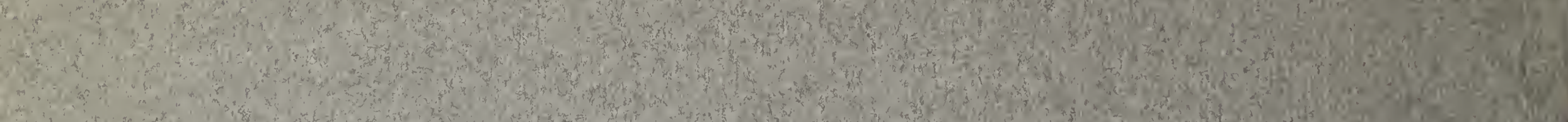

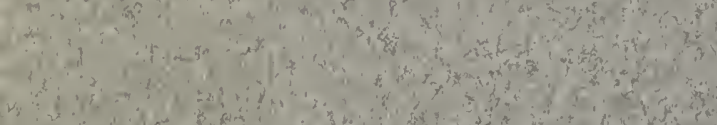

(1)

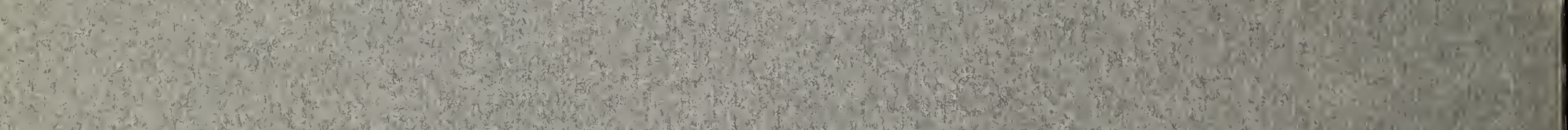

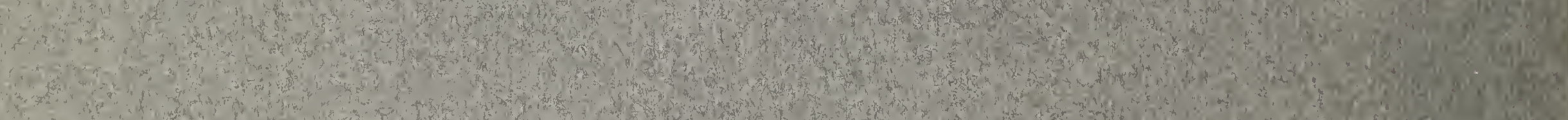

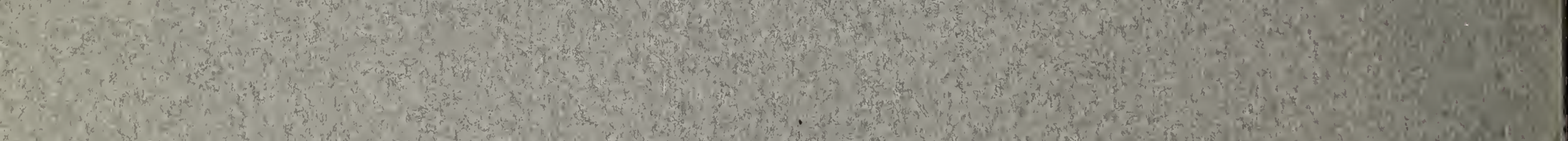
(5)

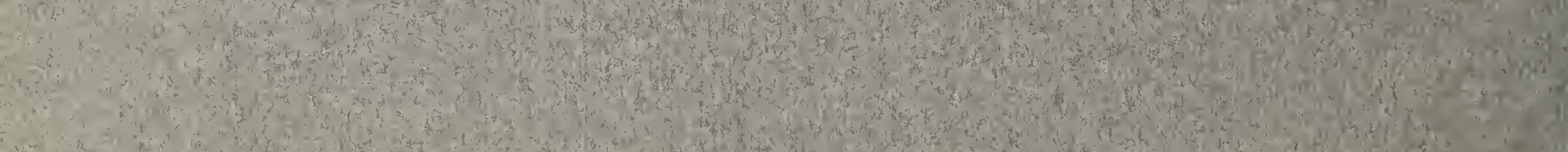
(5)

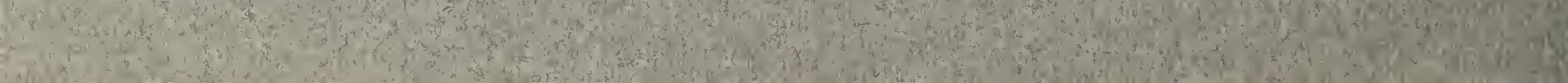

